Cover. Photograph of groundwater discharging from Pliocene gravel deposits near the South Loup River, Custer County, Nebraska. Photograph by Chris Hobza, U.S. Geological Survey. 


\section{Groundwater Discharge Characteristics for Selected Streams Within the Loup River Basin, Nebraska, 2014-16}

By Christopher M. Hobza and Aaron R. Schepers

Prepared in cooperation with the Upper Loup and Lower Loup Natural Resources Districts and the Nebraska Environmental Trust

Scientific Investigations Report 2018-5093 


\section{U.S. Department of the Interior \\ RYAN K. ZINKE, Secretary}

\section{U.S. Geological Survey James F. Reilly II, Director}

\section{U.S. Geological Survey, Reston, Virginia: 2018}

For more information on the USGS - the Federal source for science about the Earth, its natural and living resources, natural hazards, and the environment-visit https://www.usgs.gov or call 1-888-ASK-USGS.

For an overview of USGS information products, including maps, imagery, and publications, visit https://store.usgs.gov.

Any use of trade, firm, or product names is for descriptive purposes only and does not imply endorsement by the U.S. Government.

Although this information product, for the most part, is in the public domain, it also may contain copyrighted materials as noted in the text. Permission to reproduce copyrighted items must be secured from the copyright owner.

Suggested citation:

Hobza, C.M., and Schepers, A.R., 2018, Groundwater discharge characteristics for selected streams within the Loup River Basin, Nebraska, 2014-16: U.S. Geological Survey Scientific Investigations Report 2018-5093, 50 p., https:// doi.org/10.3133/sir20185093.

ISSN 2328-0328 (online) 


\section{Contents}

Acknowledgments ……..................................................................................................................

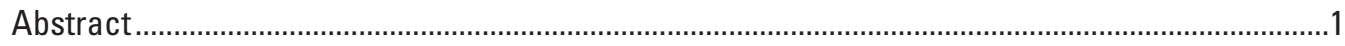

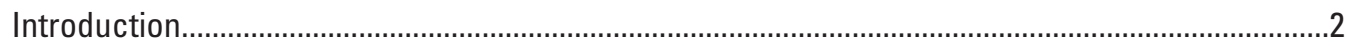

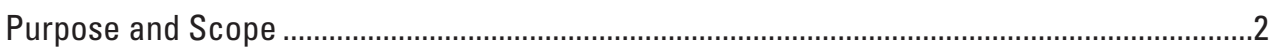

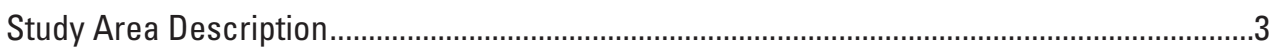

Basin and Flow Characteristics of Loup River Basin Streams................................................

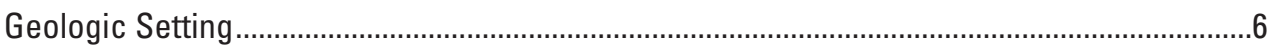

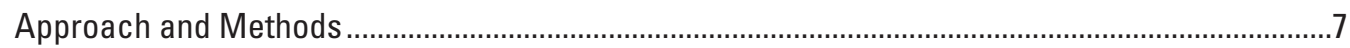

Methods Used to Describe Spatial Characteristics of Groundwater Discharge .......................7

Stream Reconnaissance Methods ............................................................................

Aerial Thermal Infrared Imagery Methods ....................................................................12

Aerial Thermal Infrared Imagery Collection............................................................13

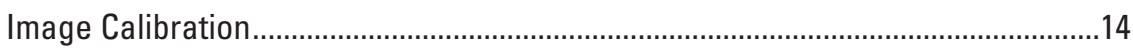

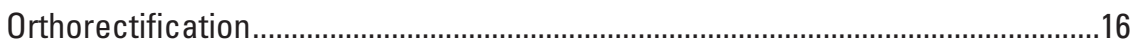

Thermal Infrared Imagery Analysis ....................................................................16

Methods Used to Describe Temporal Characteristics of Groundwater Discharge.................17

Groundwater Discharge Characteristics for Streams in the Loup River Basin .............................17

South Loup River and North Fork South Loup River...........................................................18

Upper South Loup River and North Fork South Loup River.............................................18

Middle South Loup River ...........................................................................................19

Lower South Loup River.........................................................................................27

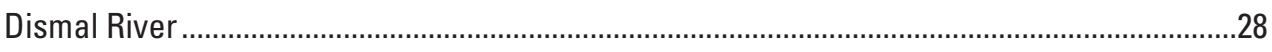

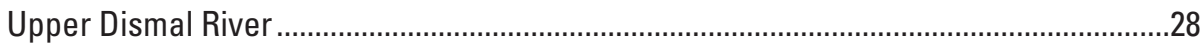

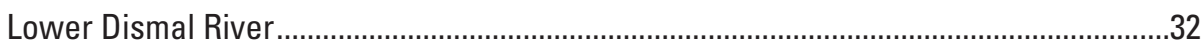

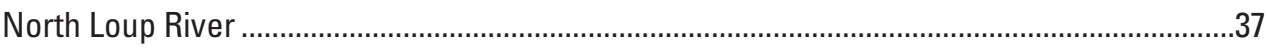

Middle Loup River ........................................................................................................ 40

Primary Controls on Groundwater Discharge Characteristics Within the Loup River Basin .........44

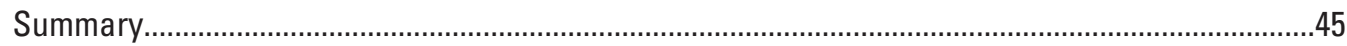

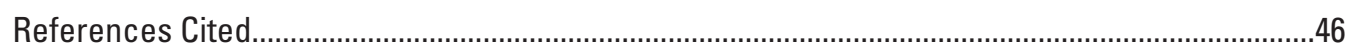

\section{Figures}

1. Map showing study area, selected stream reaches, and streamflow-gaging stations, Loup River Basin, Nebraska .

2. Graph showing flow duration curves for selected streamflow-gaging stations, Loup River Basin, Nebraska...........................................................................................

3. Map showing stream reconnaissance locations, self-logging temperature sensor locations, and reaches where aerial thermal infrared imagery was collected along the South Loup River and the North Fork South Loup River, Nebraska.

4. Map showing stream reconnaissance locations, self-logging temperature sensor locations, and reaches where aerial thermal infrared imagery was collected along the Dismal River, Nebraska 
5. Map showing stream reconnaissance locations, self-logging temperature sensor locations, and reaches where aerial thermal infrared imagery was collected along the North Loup River, Nebraska ..

6. Field photographs of a hydraulic potentiomanometer.

7. Graph showing measured streamflow and the estimated density of focused groundwater discharge points along the upper and middle South Loup River reaches and North Fork South Loup River ....

8. Map showing example aerial thermal infrared imagery collected in November 2015.

9. Graph showing downstream temperature profiles of the upper South Loup River and the North Fork South Loup River, above the South Loup River at Arnold, Nebraska, streamflow-gaging station.

10. Graphs showing South Loup River at Arnold, Nebraska, streamflow-gaging station and nearby observation well.....

11. Graph showing downstream temperature profile for the middle South Loup River created from aerial thermal infrared imagery collected December 2-3, 2015.

12. Graph showing downstream temperature profile for the middle and lower South Loup River created from aerial thermal infrared imagery collected November 23-24, 2015.

13. Map showing example aerial thermal infrared imagery from the middle South Loup River, December 2015.

14. Photographs showing two focused groundwater discharge points along the middle South Loup River.

15. Graph showing groundwater-level elevation in the South Loup River at the Pressey Park recorder well and nearby streamflow-gaging station...

16. Graph showing measured streamflow and the estimated density of focused groundwater discharge points along the lower South Loup River.

17. Graphs showing South Loup River at Saint Michael, Nebraska, streamflow-gaging station and nearby observation well.

18. Graph showing measured streamflow and the estimated density of focused groundwater discharge points along the Dismal River.

19. Photographs of example focused groundwater discharge points along the upper Dismal River.

20. Map showing example aerial thermal infrared image of Dismal River, December 2015. Photograph of the focused vertical flow conduit identified can be seen in figure $19 A$.

21. Graph showing downstream temperature profile of the upper Dismal River created from aerial thermal infrared imagery collected December 3-4, 2015.

22. Graph showing downstream temperature profile of the lower Dismal River created from aerial thermal infrared imagery collected November 19-20, 2016

23. Graphs showing Dismal River near Thedford, Nebraska, streamflow-gaging station and nearby observation well.

24. Graph showing measured streamflow and the estimated density of focused groundwater discharge points along the North Loup River

25. Graph showing downstream temperature profile of the North Loup River created from aerial thermal infrared imagery collected November 19-20, 2016.

26. Map showing example aerial thermal infrared image of the North Loup River, November 2016. 
27. Graphs showing North Loup River at Brewster, Nebraska, streamflow-gaging station and nearby observation well from May 2015 to April 2018.

28. Graphs showing North Loup River at Taylor, Nebraska, streamflow-gaging station and nearby observation well from August 2015 to January 2018.

29. Graphs showing Middle Loup River at Dunning, Nebraska, streamflow-gaging station and nearby observation well from August 2015 to January 2018.

\section{Tables}

1. Flow and basin characteristics above six streamflow-gaging stations within the Loup River Basin, Nebraska.

2. Streamflow measurement, stream reconnaissance, and self-logging temperature sensor locations

3. Site number, geographic location, and selected well construction data for observation wells drilled near streamflow-gaging stations.

4. Summary statistics for stream temperature, streambed temperature, and hydraulic gradient collected along the North Fork South Loup, South Loup, Dismal, and North Loup Rivers, Nebraska, August 2014, August or September 2015, and August 2016

\section{Conversion Factors}

U.S. customary units to International System of Units

\begin{tabular}{lcl}
\hline & Multiply & \multicolumn{1}{c}{ Bo obtain } \\
\hline inch (in.) & Length & \\
inch (in.) & 2.54 & centimeter $(\mathrm{cm})$ \\
foot (ft) & 25.4 & millimeter $(\mathrm{mm})$ \\
mile (mi) & 0.3048 & meter $(\mathrm{m})$ \\
\hline & 1.609 & kilometer $(\mathrm{km})$ \\
\hline acre & Area & \\
acre & 4,047 & square meter $\left(\mathrm{m}^{2}\right)$ \\
acre & 0.4047 & hectare $($ ha) \\
acre & 0.4047 & square hectometer $\left(\mathrm{hm}^{2}\right)$ \\
\hline & 0.004047 & square kilometer $\left(\mathrm{km}^{2}\right)$ \\
\hline cubic foot per second $\left(\mathrm{ft}^{3} / \mathrm{s}\right)$ & Flow rate & \\
gallon per minute (gal $/ \mathrm{min})$ & 0.02832 & cubic meter per second $\left(\mathrm{m}^{3} / \mathrm{s}\right)$ \\
\hline & 0.06309 & liter per second $(\mathrm{L} / \mathrm{s})$ \\
\hline foot per foot (ft/ft) & Hydraulic gradient & \\
\hline
\end{tabular}

Temperature in degrees Celsius $\left({ }^{\circ} \mathrm{C}\right)$ may be converted to degrees Fahrenheit $\left({ }^{\circ} \mathrm{F}\right)$ as follows:

$$
{ }^{\circ} \mathrm{F}=\left(1.8 \times{ }^{\circ} \mathrm{C}\right)+32 .
$$




\title{
Datum
}

Vertical coordinate information is referenced to the North American Vertical Datum of 1988 (NAVD 88).

Horizontal coordinate information is referenced to the North American Datum of 1983 (NAD 83).

Elevation, as used in this report, refers to distance above the vertical datum.

\section{Abbreviations}

\author{
ELM Elkhorn-Loup groundwater-flow Model \\ GIS geographic information system \\ GNSS Global Navigation Satellite Systems \\ GPS Global Positioning System \\ GSD ground sample distance \\ IMP integrated management plan \\ NRD Natural Resources District \\ NWIS National Water Information System \\ OPUS Online Positioning User Service \\ RMSE root mean square error \\ TIR thermal infrared \\ USGS U.S. Geological Survey
}

\section{Acknowledgments}

We thank Anna Baum, general manager at the Upper Loup Natural Resources District, and Tylr Naprstek, assistant manger at the Lower Loup Natural Resources District, for their assistance in grant writing, administration, and landowner coordination. We also thank Kyle Charron, Kyle Yrkoski, and Taylor Spencer for their assistance with landowner coordination and data collection during the stream reconnaissance. We thank landowners for graciously allowing access to their property during data collection. 


\title{
Ground water Discharge Characteristics for Selected Streams Within the Loup River Basin, Nebraska, 2014-16
}

\author{
By Christopher M. Hobza ${ }^{1}$ and Aaron R. Schepers ${ }^{2}$
}

\section{Abstract}

Streams in the Loup River Basin are sensitive to groundwater withdrawals because of the close hydrologic connection between groundwater and surface water. Groundwater discharge is the primary component of streamflow in the Loup River Basin and constitutes more than 90 percent of streamflow in the central part of the Sand Hills. To improve the understanding of geologic controls and various climatic and land-use changes on groundwater discharge, the U.S. Geological Survey (USGS), in cooperation with the Upper Loup Natural Resources District (NRD), the Lower Loup NRD, and the Nebraska Environmental Trust, studied the spatial and temporal characteristics of groundwater discharge within the Loup River Basin. This report documents the methods of data collection and analysis, which include the collection of approximately 350 river miles of aerial thermal infrared imagery and continuous groundwater-level and temperature data from six streamflow-gaging stations within the Loup River Basin.

The results from the stream reconnaissance and examination of aerial thermal infrared imagery demonstrated the influence of the surficial and subsurface geology on the spatial characteristics of groundwater discharge to streams in the Loup River Basin. At the headwaters of the South Loup River, streamflow is sustained and increased from focused groundwater discharge emanating from Quaternary deposits at many small (less than 0.1 cubic foot per second) focused points. The volume of water produced from this dense network of focused groundwater discharge points along the North Fork South Loup River is sufficient to provide approximately 40 percent of the flow measured at the South Loup River at Arnold, Nebraska streamflow-gaging station (USGS station 06781600) during the irrigation season. Approximately 5 miles downstream from the South Loup River at Arnold, Nebr., streamflow-gaging station, the river incises into Pliocene-age sand and gravel deposits, which provide additional groundwater discharge to the stream. The streamflow of the South Loup River increases by a factor of 5 across a 62-mile reach of the middle South Loup River.

Increases in streamflow along the upper Dismal River result from a dense network of focused groundwater discharge points within semiconsolidated Pliocene-age deposits. Below the Dismal River near Thedford, Nebr., streamflow-gaging station (USGS station 06775900), the Dismal River incises into the Ogallala Formation over a short reach before flowing over coarser, more permeable Quaternary-age alluvial deposits. Diffuse groundwater discharge sustains and increases the streamflow of the lower Dismal River in this reach.

Groundwater sapping was evident on some stream reaches and has increased the size and flow of focused groundwater discharge points. Previous researchers have documented streambed incision and groundwater sapping on the upper Dismal River that have created and enlarged focused groundwater discharge points capturing additional groundwater. Similar processes appear to have played a role in the formation of larger focused groundwater discharge points, which sustain the flow of the middle South Loup River. The constant flow of groundwater into the South Loup River has removed finergrained Quaternary sediments and further exposed Plioceneage gravel deposits. Headward erosion is evident where some of the large focused groundwater discharge points have incised their own draws and terminate in bowl-like depressions away from the stream.

Within the Loup River NRDs, the percentage of groundwater-irrigated land in a stream basin is one factor that affects groundwater discharge to streams. A striking example was at the South Loup River at Saint Michael, Nebr., groundwater and streamflow-gaging station (USGS station 06784000) where the shallow groundwater levels declined below the level of the stream during the middle to late part of the growing season (July to September) when consumptive groundwater use was at its peak. The South Loup River Basin above the South Loup River at Saint Michael, Nebr., streamflow-gaging

${ }^{1}$ U.S. Geological Survey.

${ }^{2}$ Cornerstone Mapping, Inc. 
station has the highest percentage of groundwater-irrigated row crops of all the basins examined in this study. Continuous groundwater and surface-water levels measured at the North Loup River at the Taylor, Nebr., streamflow-gaging station (USGS station 06786000) indicate that the stream is receiving groundwater throughout the year; however, when consumptive groundwater use peaks during the middle to late part of the growing season (July to September), the difference in elevation between the groundwater level and the stream elevation decreases, which indicates a reduction in the amount of groundwater discharge received.

\section{Introduction}

The State of Nebraska (fig. 1) requires a sustainable balance between long-term water supplies and uses of groundwater and surface water (Ostdiek, 2009) and requires Natural Resources Districts (NRDs) to include the impact of groundwater withdrawals on surface-water systems as part of their integrated management plan (IMP). Recent droughts across the State of Nebraska (2000-6; 2012-13) have amplified concerns about (1) the long-term sustainability of groundwater and surface-water resources and (2) the effect of groundwater withdrawals on streamflow in Nebraska. The Upper Loup NRD and Lower Loup NRD (fig. 1; collectively referred to as the "Loup River NRDs," in conjunction with the Nebraska Department of Natural Resources, have developed voluntary IMPs for groundwater and surface water (Lower Loup Natural Resources District, 2016; Upper Loup Natural Resources District, 2016). In an effort to support the IMPs, the Loup River NRDs are using scientifically based management practices and groundwater and surface-water monitoring to guide current and future management decisions. Towards those ends, the development of water-resource management tools, such as the Elkhorn-Loup Model (ELM; Peterson and others, 2008; Stanton and others, 2010), and long-term data collection are key components of their water management programs. Large parts of the Loup River NRDs are in the Sand Hills (fig. 1), which overlies the thickest parts of the High Plains aquifer and is drained by the Loup River system, the largest tributary of the lower Platte River, which supplies water to large municipalities in the eastern part of Nebraska (Hobza and others, 2011, 2012).

Streams in the Loup River Basin are sensitive to groundwater withdrawals because of the close hydrologic connection between groundwater and surface water (Stanton and others, 2010). Pumping from aquifers that are hydrologically connected to surface-water bodies can have a substantial effect by reducing the groundwater discharge to surface water (Winter and others, 1998). An evaluation of any groundwater management strategy needs to involve consideration of potential impacts on surface-water resources. Changes in streamflow can affect riparian habitat and water available for recreational, agricultural, commercial, and domestic uses (Peterson and others, 2008). In addition, streamflow affects the sustainability of wet meadows to support livestock, migratory and resident birds, and other biota. Currently (2018), the complexity of this system and the interaction between surface-water and groundwater resources are not fully understood.

Groundwater discharge is the primary component of streamflow in the Loup River Basin and constitutes more than 90 percent of streamflow in the central part of the Sand Hills (Szilagyi and others, 2003). Groundwater discharge has been estimated using base flow separation methods (Stanton and others, 2010) and seepage run data (Peterson and Strauch, 2007). The base flow separation technique estimates the amount of groundwater discharge as a percentage of total streamflow for the stream reach above a streamflow-gaging station. Groundwater discharge also is estimated by measuring surface-water flow at two places, as much as 15 miles (mi) apart, in a stream reach, a practice commonly known as a seepage run (Harvey and Wagner, 2000; Rosenberry and LaBaugh, 2008). Differences in measured streamflow are attributed to groundwater discharge (positive difference or increase in flow is a gaining stream) or groundwater recharge (negative difference or decrease in flow is a losing stream). A groundwater flow model simulates on a cell-by-cell basis, but is calibrated to streamflow observation points that can be miles apart. As a result, large reaches are often integrated together.

Streams in the Loup River Basin are known to receive a combination of focused discharge (groundwater discharge as springs) and diffuse discharge (relatively uniform discharge from an underlying aquifer). These areas of focused groundwater discharge have not been mapped extensively; furthermore, the effect of various climatic and land-use changes on groundwater discharge patterns is currently (as of 2018) unknown. To improve the understanding of geologic controls, such as formation permeability, and various climatic and landuse changes on groundwater discharge, the U.S. Geological Survey (USGS), in cooperation with the Upper Loup NRD, the Lower Loup NRD, and the Nebraska Environmental Trust, collected aerial thermal infrared (TIR) imagery covering about $350 \mathrm{mi}$ of streams and recorded water level and temperature at six streamflow-gaging stations within the Loup River Basin (fig. 1). The data collected for this study will improve the understanding of geologic controls on groundwater discharge and the effects of land use on streamflow.

\section{Purpose and Scope}

The purpose of this report is to describe and identify potential drivers of the spatial and temporal characteristics of groundwater discharge within the South Loup River, Dismal River, and North Loup River Basins (fig. 1). This report documents the methods of data collection and analysis, which include the collection of approximately 350 river miles of aerial TIR imagery during 2015-16 and continuous groundwater-level and temperature data from six streamflow-gaging 


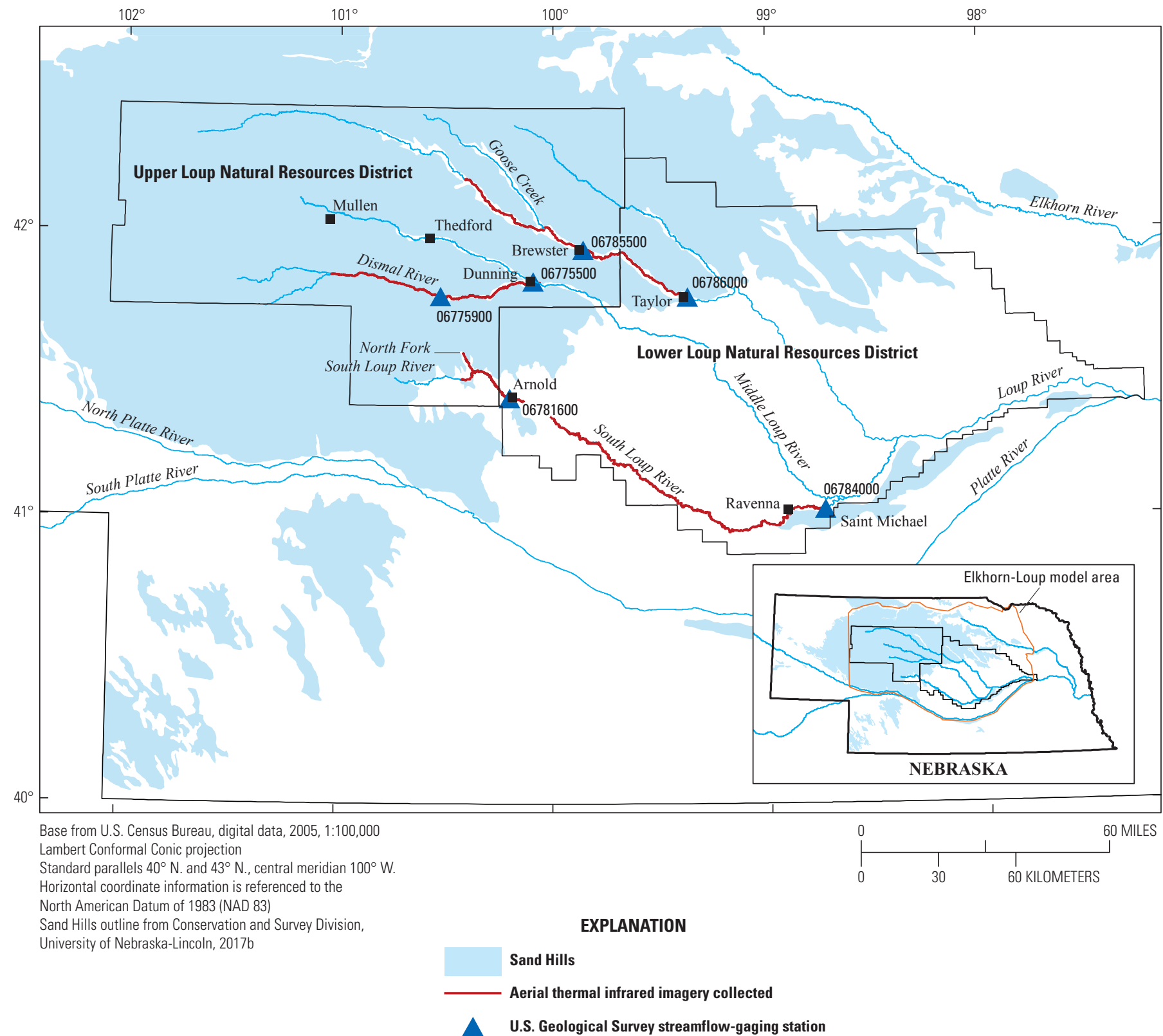

Figure 1. Study area, selected stream reaches, and streamflow-gaging stations, Loup River Basin, Nebraska.

stations within the Loup River Basin during 2014-16. These datasets were collected to improve the understanding of geologic controls and spatial patterns of groundwater discharge. The potential land-use and groundwater irrigation effects on the temporal variability of groundwater discharge also were evaluated. The aerial TIR imagery and water-level and temperature data collected are intended to enhance the understanding of groundwater discharge characteristics and to complement a seepage run (Peterson and Strauch, 2007) completed during the ELM phase 1 study (Peterson and others, 2008).

\section{Study Area Description}

The study area for this report is the Loup River NRDs; however, data collection was focused on the highlighted reaches of the North Fork South Loup, South Loup, North Loup, and Dismal Rivers (fig. 1). Physiography and land use differ across the study area. The Sand Hills covers about 56 percent of the 9.4 million-acre study area (fig. 1; Conservation and Survey Division, University of Nebraska-Lincoln, 2017b). The Sand Hills is an area with grass-covered eolian 
dunes that is dominated by undeveloped rangeland primarily used for cattle grazing (Bleed and Flowerday, 1989). The dissected loess plains, to the east of the Sand Hills, cover 34 percent of the study area (Conservation and Survey Division, University of Nebraska-Lincoln, 2017b). The dissected loess plains are characterized by nearly rolling to steep topography with flat upland tables that support a mix of row crops and rangeland. About 10 percent of the study area is classified as valleys, which are flat areas generally along rivers and larger tributaries (Conservation and Survey Division, University of Nebraska-Lincoln, 2017b). Valleys are generally well suited for irrigated row-crop agriculture, and corn and soybeans are the principal crop types (Strauch and Linard, 2009).

Groundwater use differs across the study area, and the number of irrigated acres increases from west to east. In 2013, the Upper Loup NRD reported having 71,500 irrigated acres within its 4.3 million-acre district (Nebraska Association of Resource Districts, 2013b), whereas the Lower Loup NRD reported having 1.2 million irrigated acres within its 5.1 million-acre district (Nebraska Association of Resource Districts, 2013a). Based on 2000 countywide estimates, the highest concentration of groundwater pumpage within the study area was in Custer and Buffalo Counties (not shown), near the lower reaches of the South Loup River (Hutson and others, 2004).

The climate in the study area is typical of continental midlatitude locations (Strauch and Linard, 2009), characterized by cold winters and warm summers. Precipitation within the study area increases from west to east. The average annual precipitation from 1981 to 2010 in Mullen, Nebraska (fig. 1), was 21 inches per year (in/yr). During that same period, precipitation near Ravenna, Nebr. (fig. 1), averaged $26.5 \mathrm{in} / \mathrm{yr}$ (National Climatic Data Center, 2017). Potential evaporation, similar to precipitation, is greatest during the crop-growing season of April through September. Potential evaporation peaks in July and often exceeds precipitation (Chen and others, 2003). Most of the annual groundwater recharge is in the winter and early spring when precipitation is greater than evapotranspiration. Mean annual evapotranspiration in the study area ranges from $19 \mathrm{in} / \mathrm{yr}$ in the east to $16 \mathrm{in} / \mathrm{yr}$ in the west (Dugan and Zelt, 2000).

Unique physical characteristics of the Sand Hills resulted in a substantial amount of meteoric water being stored in the groundwater system (McGuire and others, 2012; Stanton and others, 2011). Highly permeable soils allow water to infiltrate even during heavy precipitation, resulting in higher recharge rates when compared to the dissected loess plains to the east and fewer runoff-induced high-flow events. Based on a soil-water balance model approach, Stanton and others (2011) estimated annual recharge rates for the Sand Hills at $2.3 \mathrm{in} / \mathrm{yr}$. Recharge in the area to the east of the Sand Hills is variable; in areas where the dissected loess plains dominate, recharge generally decreases to $0.5 \mathrm{in} / \mathrm{yr}$ or less because of the low permeability of loess deposits (Stanton and others, 2011).

\section{Basin and Flow Characteristics of Loup River Basin Streams}

Streams within the Loup River Basin have several unique characteristics that set them apart from other streams within Nebraska. The headwaters for most major streams within the Loup River Basin are within the Sand Hills where runoff to streams is limited by the dune landscape and permeable topsoil (Bentall and Shaffer, 1979), which results in remarkably constant streamflow dominated by groundwater discharge (base flow). Basin and flow characteristics for six streamflowgaging stations are presented in table 1, and flow duration curves are presented in figure 2. Only 15 percent of the basin above the South Loup at Saint Michael, Nebr., streamflowgaging station (USGS station 06784000; hereinafter referred to as "Saint Michael streamflow-gaging station") (table 1) is covered by the Sand Hills (fig. 1). Consequently, this streamflow-gaging station also had the highest ratio of 95th and 5th percentile of ranked daily mean flow (6.44), which indicates that the Saint Michael streamflow-gaging station can experience higher flows during runoff events and lower flows in August and September when evapotranspiration rates and groundwater irrigation demands are largest. In contrast, the Dismal River near Thedford, Nebr., streamflow-gaging station (USGS station 06775900; hereinafter referred to as the "Dismal River streamflow-gaging station") is 100 percent contained within the Sand Hills (fig. 1) and recorded the lowest ratio of the 95th and 5th percentile of ranked daily mean flow (1.21), which indicates that seasonal climatic variations have little effect on streamflow.

Two streamflow-gaging stations on the North Loup River had higher ratios of 95 th and 5th percentile of ranked daily mean flow when compared to the Middle Loup River at Dunning, Nebr. (USGS station 06775500; hereinafter referred to as the "Middle Loup River at Dunning streamflow-gaging station"), and Dismal River streamflow-gaging stations to the west (table 1; fig. 1). This comparison is consistent with the findings of Chen and others (2003), who compared discharge records of streams within the western and eastern parts of the Sand Hills. Streams in the eastern part of the Sand Hills were more sensitive to periods of drought than streams in the western part. Chen and others (2003) attributed this difference to the thicker unsaturated zones, which are able to dampen varying seasonal and annual climatic effects on streamflow, in the Middle Loup and Dismal River Basins.

As streams flow out of the Sand Hills, groundwater discharge, which Stanton and others (2010) define as base flow, ranges from about 80 to 95 percent of total streamflow. When these streams cross the dissected and loess-covered plains to the south and east, they receive less groundwater discharge and more surface runoff. The groundwater discharge fraction of streamflow drops to between about 60 and 80 percent. As streams flow eastward, and the percentage of area covered by the Sand Hills decreases, the percentage of irrigated cropland increases because soils developed in the dissected loess 
Table 1. Flow and basin characteristics above six streamflow-gaging stations within the Loup River Basin, Nebraska.

[Q95, 95th percentile of ranked daily mean flows over the period of record; Q5, 5th percentile of ranked daily mean flows over the period of record; Q95/Q5, the ratio between the 95th percentile of ranked daily mean flows and the 5th percentile of ranked daily mean flows over the period of record; Sand Hills area, percentage of associated river basin covered by the Sand Hills; Land-use area, percentage of associated river basin; I, irrigated cropland; DL, dryland crops; R/U, rangeland, undeveloped; WW, wetlands or water; D, developed; Nebr., Nebraska]

\begin{tabular}{|c|c|c|c|c|c|c|c|c|c|c|c|}
\hline \multirow[b]{2}{*}{ Station name } & \multirow{2}{*}{$\begin{array}{l}\text { Station } \\
\text { number }\end{array}$} & \multirow{2}{*}{$\begin{array}{l}\text { Period of } \\
\text { record }\end{array}$} & \multirow{2}{*}{$\begin{array}{c}095^{1} \\
\text { (cubic foot } \\
\text { per second) }\end{array}$} & \multirow{2}{*}{$\begin{array}{c}05^{1} \\
\text { (cubic foot } \\
\text { per second) }\end{array}$} & \multirow[b]{2}{*}{$095 / 05$} & \multirow{2}{*}{$\begin{array}{c}\text { Sand Hills } \\
\text { area }^{2} \\
\text { (percent) }\end{array}$} & \multicolumn{5}{|c|}{ Land-use area ${ }^{3}$ (percent) } \\
\hline & & & & & & & I & DL & $\mathbf{R} / \mathbf{U}$ & WW & D \\
\hline Middle Loup River at Dunning, Nebr. & 06775500 & $2006-15$ & 577 & 408 & 1.41 & 98.4 & 0.05 & 0.03 & 95.18 & 4.34 & 0.39 \\
\hline Dismal River near Thedford, Nebr. & 06775900 & $2006-15$ & 250 & 207 & 1.21 & 100 & 0.14 & 0.08 & 97.29 & 2.38 & 0.11 \\
\hline South Loup River at Arnold, Nebr. & 06781600 & $2011-15$ & 63.6 & 13.3 & 4.78 & 57.9 & 10.54 & 2.91 & 83.63 & 1.02 & 1.89 \\
\hline South Loup River at Saint Michael, Nebr. & 06784000 & $2006-15$ & 399 & 62 & 6.44 & 14.6 & 21.22 & 2.47 & 70.82 & 1.52 & 3.96 \\
\hline North Loup River at Taylor, Nebr. ${ }^{4}$ & 06786000 & $2006-15$ & 942 & 240 & 3.93 & 91.6 & 0.56 & 0.15 & 94.03 & 4.64 & 0.62 \\
\hline
\end{tabular}

${ }^{1}$ U.S. Geological Survey, 2017.

${ }^{2}$ From Conservation and Survey Division, University of Nebraska, 2017b.

${ }^{3}$ Land-use data from 2009 in Peterson and others, 2016.

${ }^{4}$ Flows affected by diversion into Taylor-Ord Canal.

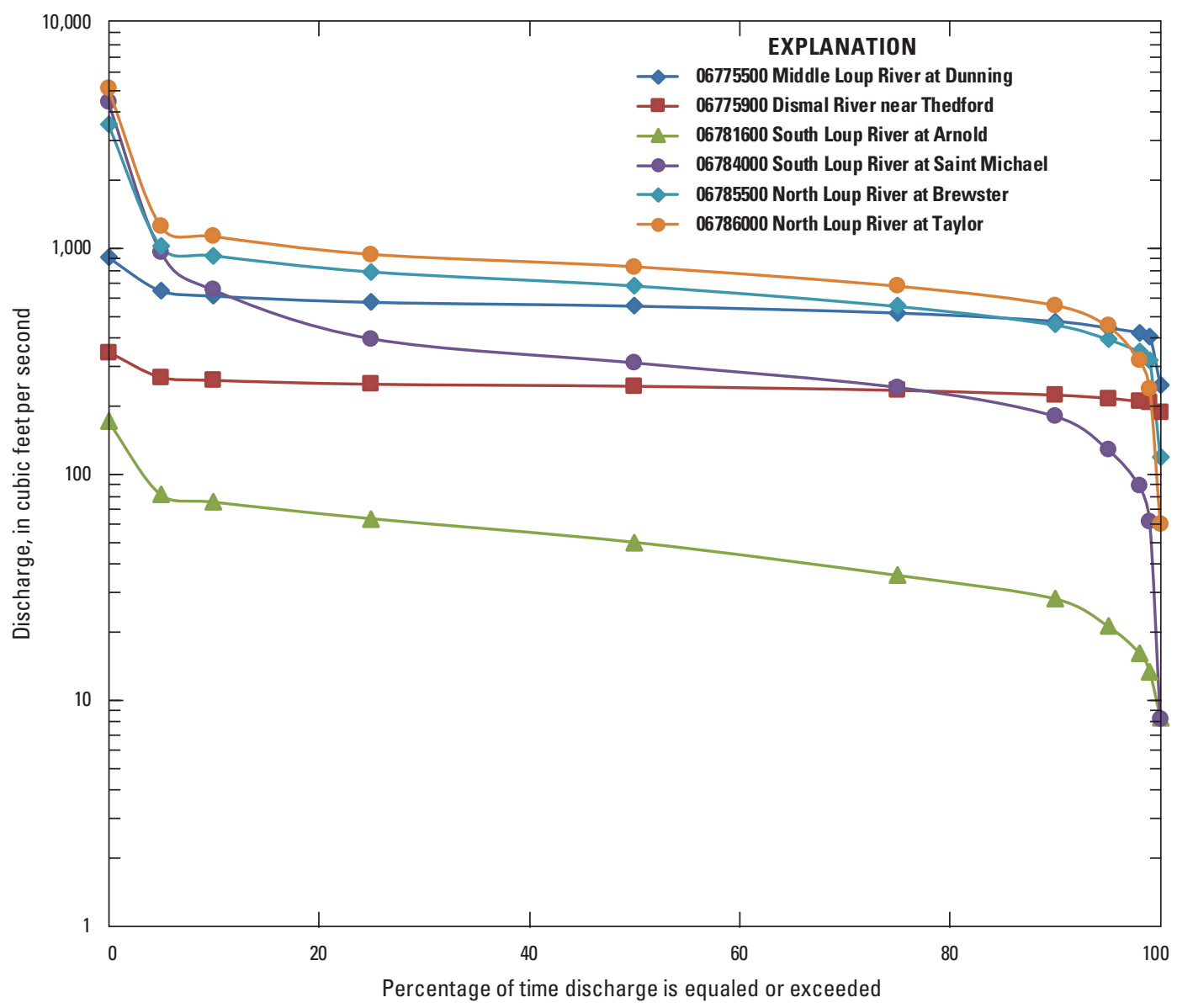

Figure 2. Flow duration curves for selected streamflow-gaging stations, Loup River Basin, Nebraska. 
plains and valleys are more conducive to row-crop production. Increased groundwater pumping during the growing season reduces the amount of groundwater discharge received by streams (Peterson and others, 2008; Stanton and others, 2010), which affects the flow characteristics shown in figure 2 and table 1 .

Compared to other streams within Nebraska, streams in the Sand Hills are relatively young, and their drainage networks still may be developing (Maher and others, 2003). Using radiocarbon age dates (Ahlbrandt and others, 1983), researchers have estimated that the modern Dismal River valley is 3,000 years old or less (Swinehart and Diffendal, 1989), and the channel of the Dismal River has incised at a rate of 3.3 feet (ft) per 100 years over the past 1,500 years (Maher and others, 2003). Groundwater sapping, which is the process where headward migration of the stream or tributary channels happens in response to erosion caused by constant discharge of groundwater, is still evident today. Guhman and Pederson (1992) studied a reach of the Dismal River above the Dismal River near Thedford, Nebr., streamflow-gaging station and noted focused groundwater discharge and "boiling" sand springs that were actively eroding sediments. Groundwater sapping has resulted in the formation of amphitheater like cavities and headward erosion of tributaries. These active processes indicate that the Dismal River drainage network is still developing and potentially capturing additional groundwater, which increases streamflow.

\section{Geologic Setting}

The study area overlies the High Plains aquifer system, where saturated thicknesses can exceed 1,000 ft (McGuire and others, 2012). The High Plains aquifer system is considered to be inclusive of all hydrologically connected Tertiary- and Quaternary-age units. According to Gutentag and others (1984), the Tertiary-age units include the fractured part of the Oligocene-age Brule Formation of the White River Group (hereinafter referred to as "the Brule"), the Miocene-age Arikaree Group (hereinafter referred to as "the Arikaree"), and the Miocene-age Ogallala Formation (hereinafter referred to as "the Ogallala"). The Quaternary-age units include alluvial and eolian deposits. The unfractured Brule or, where the Brule is not present, the Cretaceous Pierre Shale generally form the base of aquifer. The base of aquifer surface generally dips 8 feet per mile ( $\mathrm{ft} / \mathrm{mi}$ ) east and contains paleovalleys that also drain eastward (Peterson and others, 2008).

The geologic history relevant to this study begins about 70 million years ago with the deposition of Cretaceous-age sediments. During the Cretaceous period, much of the study area was covered by a shallow inland sea, where marine sediments were deposited to form the Dakota Sandstone, Carlile Shale of the Colorado Group, the Niobrara Formation of the Colorado Group (hereinafter referred to as "the Niobrara"), and Pierre Shale. After regression of the Cretaceous sea, uplift resulted in the formation of the Chadron and Cambridge arches trending from northwest to southeast across the study area (Swinehart and others, 1985). Subsequent fluvial erosion removed as much as $1,800 \mathrm{ft}$ of the Cretaceous section and created a structural low over the previously uplifted region.

In the western part of the study area, the unfractured Brule forms the base of aquifer. The Brule is a massive siltstone consisting of primarily eolian silt but also containing some alluvium. Deposits of volcaniclastic sediments and some ash derived from volcanic complexes from the western United States make up most of its volume in some localities (Souders, 2000). When unfractured, the Brule is impermeable relative to the overlying units.

Overlying the Brule is the Arikaree, which is largely limited to the western part of the study area but may exist in paleovalleys to the east (Swinehart and Diffendal, 1989). The Arikaree is a massive, very fine- to fine-grained sandstone with localized beds of volcanic ash, silty sand, and sandy clay (Darton, 1903; Condra and Reed, 1943). The Arikaree is considered part of the High Plains aquifer system; however, it does not yield large quantities of water to wells (Gutentag and others, 1984). Within the study area, the Arikaree typically is not used as a water source.

The Ogallala is the principal geologic unit in the High Plains aquifer system and reaches a thickness of $800 \mathrm{ft}$ beneath the study area (Diffendal, 1991). The Ogallala consists of a poorly sorted mixture of sand, silt, clay, and gravel (Condra and Reed, 1943). The Ogallala is generally unconsolidated or weakly consolidated but can contain layers of sandstone cemented by calcium carbonate or limestone. When covered by younger deposits, the Ogallala has not been subdivided into stratigraphic units recognized in other areas because of the difficulty correlating these units in the subsurface (Swinehart and others, 1985). The Ogallala was deposited by aggrading streams that filled paleovalleys that were eroded into pre-Ogallala rocks (Swinehart and others, 1985). The base of the Ogallala is a complex surface formed from multiple episodes of erosion. The locations of Ogallala paleovalleys have been suggested by previous researchers (Swinehart and Diffendal, 1989; Swinehart and others, 1985), but these may represent only a fraction of the drainage network that existed during Miocene time. Much of the deposition was restricted to valleys along drainage systems originating from mountains in Wyoming and Colorado (Swinehart and others, 1985), but deposition may have been on broad low-relief plains as well (Swinehart and Diffendal, 1989).

An unconformity of at least 1.5 million years separates the Ogallala from the Pliocene-age Broadwater Formation and the Pleistocene-age Long Pine Formations (Swinehart and Diffendal, 1989); the Pleistocene Long Pine Formation unit name is used by the University of Nebraska-Lincoln, Conservation and Survey Division but is not formally recognized by the USGS. These fluvial sediments, eroded from central Wyoming and northern Colorado (Stanley and Wayne, 1972), are unevenly deposited and preserved, contain coarse sand and gravel separated by finer-grained deposits, and cover the Ogallala through much of the study area. Swinehart and Diffendal 
(1989) have identified an area within Thomas, Hooker, and McPherson Counties (not shown in fig. 1) where Pliocene-age gravels are absent. In the study area, Pliocene- and Pleistocene-age fluvial deposits average $50 \mathrm{ft}$ in thickness, but can be as thick as $300 \mathrm{ft}$ (Swinehart and Diffendal, 1989), and are hydrologically connected with the underlying Ogallala. The Broadwater and Long Pine Formations, as parts of the High Plains aquifer system, are used as a water source, where present. Distinguishing the age of some of these deposits is difficult, if not impossible (Condon, 2005).

Quaternary deposits, which consist of eolian sand, wind-deposited silt, clay, and fine-grained sand (together called loess), and alluvial deposits of sand and gravel cover much of the study area. Researchers (Ahlbrandt and others, 1983; Loope and Swinehart, 2000) have documented the radiocarbon ages of organic material within eolian deposits to reconstruct dune activity during the Holocene. Results indicated a complex history of deposition within streams and valleys and documented major periods of dune mobilization and activity 6,000 and 3,000 years before present. Quaternary-age alluvial sand and gravel are in modern stream valleys and often are used as a water source. Where thicknesses are sufficient, these coarse deposits can sustain well withdrawals of more than 1,000 gallons per minute (63 liters per second) (Peterson and others, 2008). Quaternary deposits can be as thick as $700 \mathrm{ft}$ but typically are 150 to $300 \mathrm{ft}$ thick and are absent from uplands near the Niobrara River (not shown) at the northern border of the ELM area (fig. 1; Conservation and Survey Division, University of Nebraska-Lincoln, 2017a).

\section{Approach and Methods}

This section of the report describes the methods of data collection and analysis used to improve upon the understanding of the spatial and temporal characteristics of groundwater discharge for streams in the Loup River Basin. The methods used to describe the spatial characteristics of groundwater discharge are divided into two sections. The first section describes the stream reconnaissance methods, which provided additional field data, including discharge, stream and streambed temperature, and hydraulic potentiomanometer (referred to hereinafter as "potentiomanometer") measurements to support interpretations of the aerial TIR imagery. The next subsection describes the aerial TIR imagery methods, which provide information on data collection, processing, and interpretation of approximately 350 river miles of aerial TIR imagery, which were used to describe the spatial patterns of groundwater discharge. The methods used to describe temporal characteristics of groundwater discharge for data collection and analysis, which include the collection and analysis of water-level and temperature data at six streamflow-gaging stations, are described in a separate subsection.

\section{Methods Used to Describe Spatial Characteristics of Groundwater Discharge}

Stream reaches where additional information on groundwater discharge was needed were selected by the Loup River NRDs to support their voluntary IMPs. These reaches included parts of the South Loup, Dismal, and North Loup Rivers (fig. 1). Within these reaches, the stream reconnaissance focused on specific locations where aerial TIR imagery was collected. The collection of discharge, point-scale stream and streambed temperature, and potentiomanometer measurements would provide useful data in combination with the aerial TIR imagery to assess spatial patterns in groundwater discharge.

\section{Stream Reconnaissance Methods}

The objective of the stream reconnaissance during 201416 was to collect additional field data at selected locations along the South Loup (fig. 3), Dismal (fig. 4), and North Loup Rivers (fig. 5) to support interpretations of aerial TIR imagery. Location selection involved examining several data sources including geologic maps, which could indicate changes in subsurface geology adjacent to the stream; aerial photography for features such as active gravel mines and tributaries; and historical streamflow data. The stream reconnaissance was completed during the summer months when the difference between stream temperatures and streambed temperatures would be largest. During this time of year, cooler streambed temperatures would indicate areas of focused groundwater discharge.

Streamflow was measured at selected locations (figs. 3, 4, and 5) using a handheld acoustic Doppler velocimeter in accordance with the guidelines and recommendations stated in Turnipseed and Sauer (2010) and the USGS Office of Surface Water (U.S. Geological Survey, 2004). Streamflow measurements are given in table 2 and stored in the USGS National Water Information System (NWIS; U.S. Geological Survey, 2017). Streamflow measurements collected in 2006 as part of a seepage run used in the ELM phase 2 groundwater model (Peterson and Strauch, 2007), are included in table 2 for comparison with streamflow measurements collected from 2014 to 2016. One important difference between these two sets of streamflow measurements is the fact that the seepage run measurements (Peterson and Strauch, 2007) were collected in November, which likely represents base flow conditions because there was little precipitation over the study area before and during the time the measurements were made; therefore, there was little surface runoff to streams. Generally speaking, groundwater irrigation for row crops has ceased in September, giving impacted stream reaches time to recover. Furthermore, riparian vegetation in the study area was dormant this time of year, so transpiration of shallow groundwater by plants was minimal and did not affect groundwater discharge (Peterson and Strauch, 2007). 


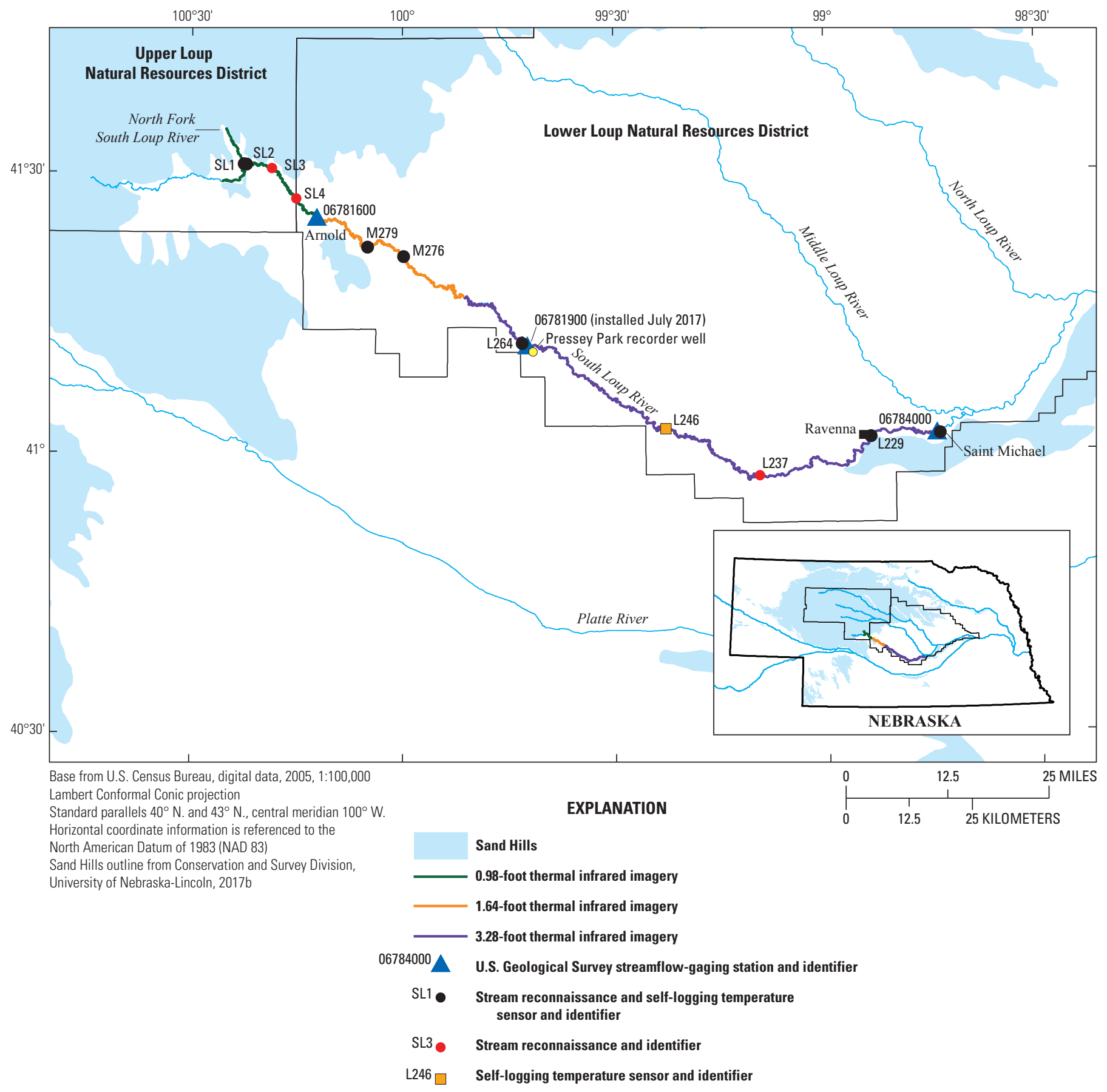

Figure 3. Stream reconnaissance locations, self-logging temperature sensor locations, and reaches where aerial thermal infrared imagery was collected along the South Loup River and the North Fork South Loup River, Nebraska. 


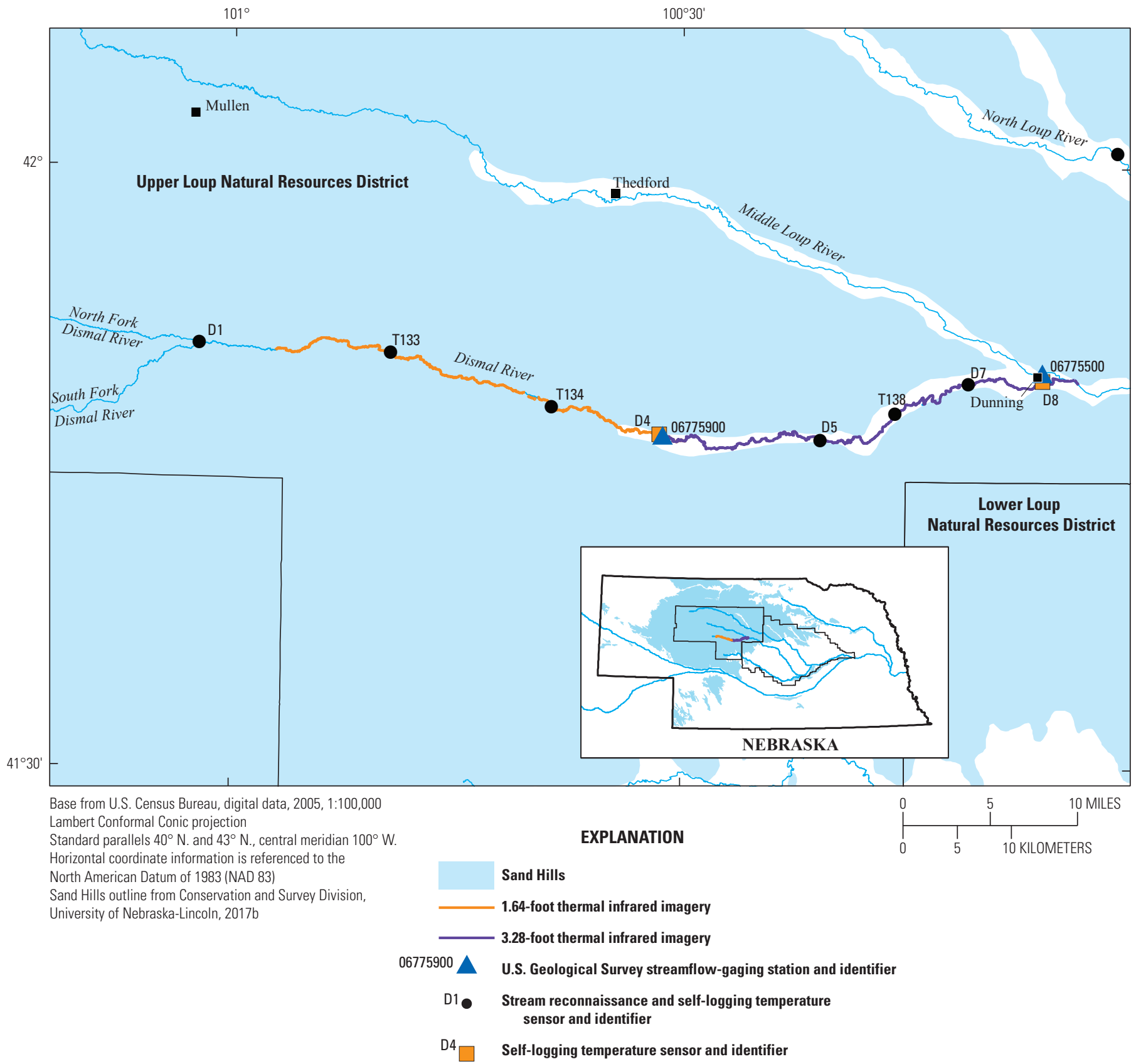

Figure 4. Stream reconnaissance locations, self-logging temperature sensor locations, and reaches where aerial thermal infrared imagery was collected along the Dismal River, Nebraska. 


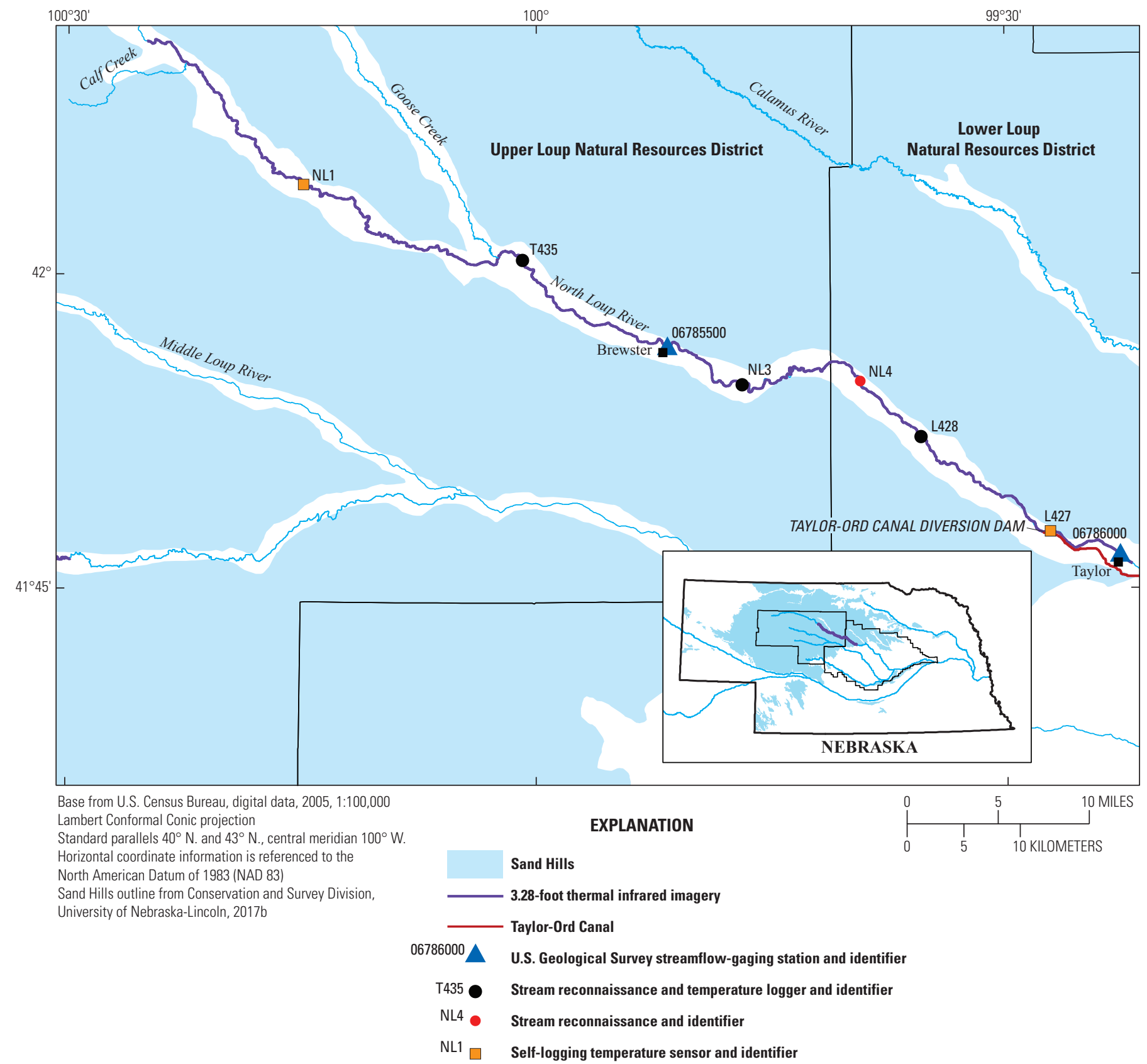

Figure 5. Stream reconnaissance locations, self-logging temperature sensor locations, and reaches where aerial thermal infrared imagery was collected along the North Loup River, Nebraska. 


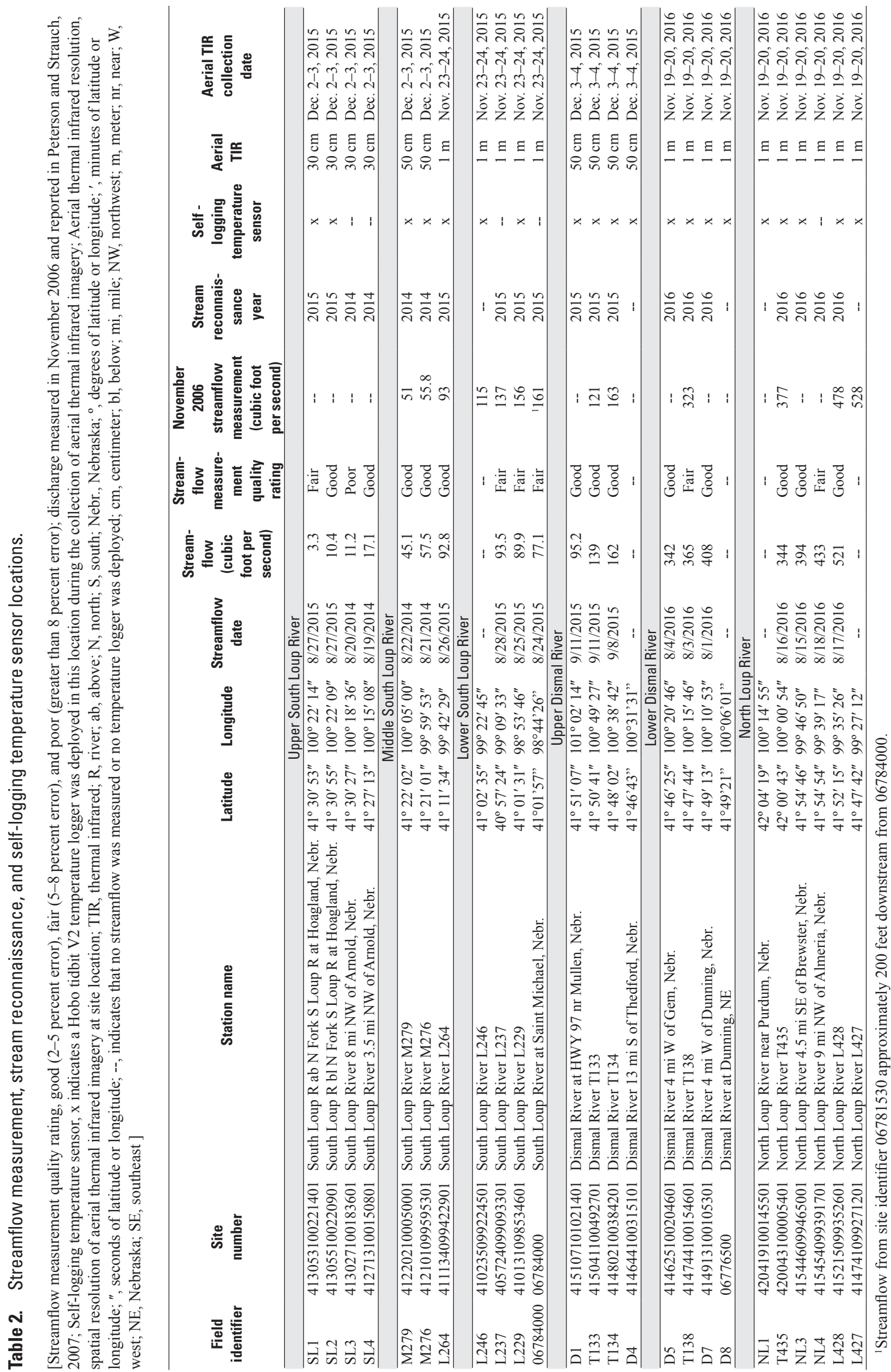


Stream temperature, streambed temperature, and potentiomanometer measurements were collocated, typically at five points along a stream transect. At the headwaters of the South Loup River, collocated measurements were collected at only three points because the stream width generally was less than $20 \mathrm{ft}$. The first transect was completed in the location of the streamflow measurement cross section, and succeeding transects moved upstream or downstream from that initial set of measurements. Stream reconnaissance locations are given in table 2. Point-measurement locations were recorded with a handheld Magellan MobileMapper CX (Magellan, 2007) Global Positioning System (GPS) unit. The horizontal precision is generally submeter, which was considered adequate for comparison of measurements across stream transects and stream reaches. Stream temperature, streambed temperature, and potentiomanometer measurements are stored in the NWIS (U.S. Geological Survey, 2017) and are available as a USGS data release (Hobza and Densmore, 2018).

Stream temperature and streambed temperature were collected with an Omega DP8891 waterproof thermometer (Omega, 2017). An advantage to using this thermometer was that it is equipped with an 18-inch (in.) precision thermistor that could be inserted into the streambed. The manufacturer's rated accuracy was plus or minus $( \pm) 1$ degree Celsius $\left({ }^{\circ} \mathrm{C}\right)$ with a precision of $\pm 0.1{ }^{\circ} \mathrm{C}$. Before data collection in the field, the thermometer was tested against a National Institute of Standards and Technology (NIST)-certified thermometer, which indicated that the Omega thermometer was within $0.2{ }^{\circ} \mathrm{C}$ at five different points, bracketing the expected environmental temperature range. Stream temperature was measured by holding the probe near the middle of the water column, allowing adequate time for the temperature to equilibrate within the probe. Stream temperature, which is strongly dependent on air temperature, typically displays diurnal temperature variation; with minimum temperature occurring around sunrise and maximum temperature before sunset. Stream temperatures collected during a typical field day often missed the daily minimum but captured the daily maximum stream temperature. Streambed temperature was collected by pushing the probe into the streambed until refusal was reached, generally less than 12 in. below the streambed surface, allowing adequate time for the temperature to equilibrate within the probe. The streambed temperature within the hyporheic zone is moderated by groundwater discharged from the underlying aquifer.

A potentiomanometer measures the difference in hydraulic head between groundwater and surface water in a lake or streambed (Winter and others, 1988; Rosenberry and LaBaugh, 2008). The vertical hydraulic gradient can be determined by dividing the difference in hydraulic head by the depth of a mini-piezometer screen, which is inserted into the underlying sediments. The direction of the vertical hydraulic gradient is important because it indicates whether a surfacewater body is gaining or losing flow to the groundwater system. The construction of a potentiomanometer and potential applications are further described in Winter and others (1988) and Rosenberry and LaBaugh (2008).
The potentiomanometer used in the study consists of a mini-piezometer connected with a clear piece of flexible tubing to an inverted wishbone-shaped tube called a manometer (fig. 6A). The other side of the manometer is connected to a tube that is submerged below the surface of the stream. A measurement was made by inserting the mini-piezometer (fig. $6 A$ ) into the streambed to a target depth of $2 \mathrm{ft}$. This depth sometimes was shallower because semiconsolidated deposits were within the streambed. The tubing on the stream side of the manometer is clamped off while water is pumped through the screen of the mini-piezometer from the top of the manometer. Once the water reaches the top of the manometer, the tubing connected to the mini-piezometer is clamped off; then, the clamp on the stream tubing is opened. Water is pumped from the top of the manometer through the stream tubing until the water reaches the top of the manometer. When all the tubing is filled with water and free of bubbles, air is bled into the manometer until the water levels appear on both sides of a ruler installed on a board next to the manometer. After leveling the manometer board with a hand level and allowing time for the water levels to equilibrate (typically 10 minutes for coarse-grained sediments), the water levels were measured. The difference in water levels is a measure of the pressure or hydraulic head difference between the groundwater (streambed) and the surface water (stream; fig. $6 B$ ). The difference in water levels is divided by the depth of the midpoint of the piezometer screen to determine the hydraulic gradient.

Potentiomanometer measurements were collected in 2014 and 2015 using the design described in Winter and others (1988). Two additional potentiomanometers were constructed and used in 2016 to increase efficiency. Although the basic concept of operation remains the same, the construction was modeled after the design described in Kennedy and others (2007); however, no oil, which can resolve much smaller head differences, was used in the manometer tube. Based on data collected in 2014 and 2015, the use of oil in the device was considered unnecessary.

\section{Aerial Thermal Infrared Imagery Methods}

Civilian use of TIR remote sensing began in 1968 when systems first were declassified by the military. Because of the relatively coarse resolution of some of the early TIR systems, mapping ocean (Anding and Kauth, 1970) and lake temperatures was the primary research focus through the 1980s (Atwell and others, 1971; Dugdale, 2016). A local example includes a study by Rundquist and others (1985) that used TIR in Nebraska to study groundwater discharge patterns in the Crescent Lake National Wildlife Refuge area (not shown) in the western part of the Sand Hills. As more sophisticated TIR technology became available for civilian use, relatively inexpensive, high-precision systems were developed enabling the use of TIR for mapping temperatures of river and stream systems (Dugdale, 2016). Researchers have applied TIR remote sensing to assess reach- and watershed-scale streamtemperature patterns (Atwell and others, 1971; Torgersen and 

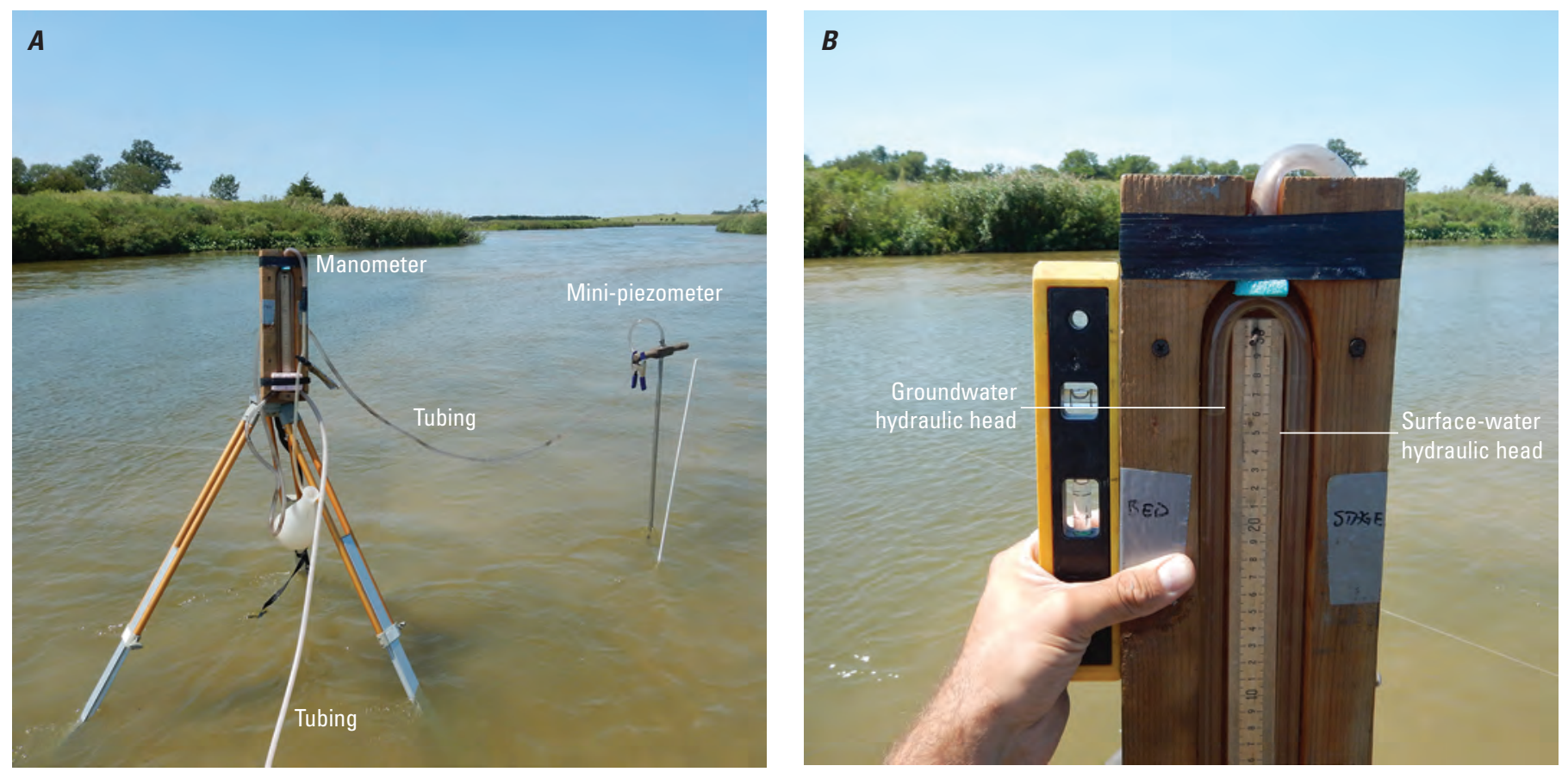

Figure 6. Field photographs of a hydraulic potentiomanometer. $A$, The major components of a hydraulic potentiomanometer. $B$, A typical measurement that indicated a higher hydraulic head in the groundwater (left side of board) compared to the surface water (right side of board).

others, 2001), identify thermal refugia and habitat suitability for fish in streams (Dugdale and others, 2015; Torgersen and others, 1999; Vatland and others, 2015), and identify zones of groundwater discharge into streams and estuaries (Banks and others, 1996; Liu and others, 2016; Loheide and Gorelick, 2006; Culbertson and others, 2014). Dugdale (2016) published a summary of recent TIR-based studies since 2011 and has documented an increase in published articles since 1995.

\section{Aerial Thermal Infrared Imagery Collection}

Advancements in aerial TIR remote-sensing technology have improved its utility for evaluating basin-wide groundwater discharge patterns because of the ability to cover entire stream systems with high-resolution imagery using fixed-wing aircraft. Groundwater discharge can be detected using thermal imaging technology because of the temperature difference between stable groundwater temperature and seasonally variable surface-water temperature. Temperature differences between groundwater and surface water are greatest during the summer and winter months. It is possible to identify and delineate areas of focused groundwater discharge by mapping stream surface temperatures (Banks and others, 1996). TIR sensors measure radiant energy from an object; therefore, the temperature measured from a river is representative of the top $0.0001 \mathrm{ft}$ of the stream (Torgersen and others, 2001). As a result, groundwater discharge through streambeds within deeper parts of the stream channel may go undetected because of the extinction of the thermal signal because of stream mixing.
For this study, aerial TIR imagery was collected with a FLIR midwave TIR camera, model SC8303 (FLIR, 2011) mounted to the belly of a Cessna Turbo 206 for all 2015 flights and a Piper Saratoga for all 2016 flights. The FLIR SC8303 has a $0.3{ }^{\circ} \mathrm{C}$ sensitivity in the 3 - to 5-micron range and an absolute temperature accuracy of $2{ }^{\circ} \mathrm{C}$ across a range from -20 to $500{ }^{\circ} \mathrm{C}$ (FLIR, 2011). The FLIR SC8303 camera was controlled by custom software designed for airborne data acquisition. The camera was tightly integrated with a flight management system, a survey-grade airborne GPS and inertial measurement unit. Flight lines were designed before each flight to optimize data acquisition over the meandering streams. The contractor used the preplanned flight lines and the flight management system to ensure proper flying altitude and to provide course guidance. The GPS logged actual X, Y, and $\mathrm{Z}$ location data. The inertial measurement unit logged roll, pitch, and yaw orientation data for the camera.

Stream width, which is an important consideration in flight planning, differs depending on location. Stream widths of the planned study reaches ranged from less than $10 \mathrm{ft}$ to approximately $300 \mathrm{ft}$. A minimum number of 10 image pixels was desired to detect and map groundwater discharge. Based on that criterion, stream reaches were flight planned for either a 0.98-, 1.64-, or 3.28-ft ground sample distance (GSD) based on a representative stream width. Image spatial resolution is a function of lens focal length and the aircraft altitude during image collection. A higher altitude reduces spatial resolution because of the increased effective "footprint" or field of view of the thermal camera. An increased field of view requires less maneuvering and effort for the aircraft to adequately cover a 
meandering stream and adjacent low-lying areas, reducing the cost of data collection. The dates of data collection and spatial resolution of TIR imagery for each dataset are given in table 2 .

The thermal imagery was collected when the temperature difference of groundwater compared to surface water would be at its maximum to optimize the detection of groundwater discharge. Aerial TIR was collected in late fall 2015 and 2016, before the onset of ice, when the stream temperature is near freezing (near $0{ }^{\circ} \mathrm{C}$ ) and groundwater temperature is typically around $13{ }^{\circ} \mathrm{C}$ (U.S. Geological Survey, 2017). This time of year has the advantage of minimal leaf and vegetative cover obstructing an overhead view of the stream surface. Aerial TIR imagery was collected at nighttime to reduce the potential effects of solar reflection on the stream surface and eliminate thermal loading of the land and stream surface. As nighttime low temperatures pushed stream temperatures towards freezing, project personnel monitored the water temperature data collected at specific streamflow-gaging stations and weather forecasts. Caution was used to ensure that stream temperatures remained above freezing so that edges were not obscured by shore ice, which potentially could mask some focused groundwater discharge points.

In late fall 2015 (table 3), aerial TIR imagery was collected along the South Loup River and the upper Dismal River. Aerial TIR imagery was collected with a fixed-wing aircraft over approximately $193 \mathrm{mi}$ of the South Loup River, starting near its headwaters above the confluence of the North Fork South Loup River to the Saint Michael streamflowgaging station (fig. 3). Aerial TIR imagery also was collected along $4 \mathrm{mi}$ of the North Fork South Loup River from its headwaters to its confluence with the South Loup River. Stream surface temperatures also were mapped along the upper Dismal River, which begins at the confluence with the North Fork and the South Fork of the Dismal River and continues east $34 \mathrm{mi}$ to the Dismal River streamflow-gaging station (fig. 4). In late fall 2016 (table 3), aerial TIR imagery was collected along the lower Dismal River (fig. 4) and the North Loup River (fig. 5). The lower Dismal River begins at the Dismal River streamflow-gaging station and continues east $37 \mathrm{mi}$ to its confluence with the Middle Loup River (fig. 4). Aerial TIR imagery was collected along $82 \mathrm{mi}$ of the North Loup River, starting 2 mi above the confluence of Calf Creek to the North Loup River at Taylor, Nebr., streamflow-gaging station (USGS station 06786000; hereinafter referred to as the “Taylor streamflow-gaging station") (fig. 5).

\section{Image Calibration}

Before aerial TIR imagery was collected, self-logging temperature sensors (Onset, 2017) were deployed at various locations within the stream (table 2; figs. 3,4 , and 5) to complement the network of thermistors at streamflowgaging stations (table 1). The recorded water temperature data were used to ground truth and correct the aerial TIR data as described in the next paragraph. Before deployment, the accuracy of all self-logging temperature sensors was verified by completing five-point temperature checks bracketing the expected range of environmental temperatures (Wagner and others, 2006). The temperature checks indicated that all selflogging temperature sensors were within $\pm 0.2^{\circ} \mathrm{C}$ of the NISTmeasured temperature over a range from 0 to $30^{\circ} \mathrm{C}$. Selflogging temperature sensors were placed inside a small section of polyvinyl chloride (PVC) pipe with holes drilled in it to allow water to flow past the logger. The pipe was attached to a t-post driven into the streambed. Cross-sectional temperature measurements collected at the time of deployment indicated that streams were well mixed at all logger locations. Side-byside temperature check measurements, as described in Wagner and others (2006), verified that the self-logging temperature sensors experienced minimal sensor drift through the duration of the deployment. Self-logging temperature sensor locations were recorded with a handheld Magellan MobileMapper CX (Magellan, 2007) GPS unit. Recorded water temperature data are stored in the NWIS (U.S. Geological Survey, 2017).

A TIR camera does not measure the surface temperature directly; rather, the camera images the emitted infrared radiation from an object. Images of the emitted infrared radiation can be corrected to produce an accurate image of surface temperatures by estimating the emissivity of the object, atmospheric temperature, relative humidity, the distance between the object and the camera (altitude), and the reflected apparent temperature. The FLIR ResearchIR v4.0 (FLIR, 2014b) software package was used to compensate for these effects and produce images that represent the true temperature of the stream and adjacent areas. Reference temperatures (recorded stream temperatures) from the self-logging temperature sensors and thermistors at streamflow-gaging stations collected at the time of the aerial TIR data collection were used as validation points. The emissivity, which is the effectiveness of the target (water) surface to emit energy as thermal radiation, was estimated from published literature (FLIR, 2014a). Other variables such as atmospheric temperature, relative humidity, and atmospheric transmissivity were adjusted iteratively such that the best fit was achieved across all reference temperatures with corresponding points on the TIR imagery.

The root mean square error (RMSE) was calculated for each stream to assess the accuracy of the stream temperatures derived from corrected TIR imagery (Mikhail and others, 2001). The RMSE was quantified as the difference between the measured stream temperature and the corrected aerial TIR temperature using the following equation:

$$
R M S E=\sqrt{\frac{\sum(\text { Tmeas }- \text { Tcorr })^{2}}{n}}
$$

where

RMSE is the root mean square error in degrees Celsius,

Tmeas is the temperature measured by the selflogging temperature sensors or thermistors at the streamflow-gaging stations, 


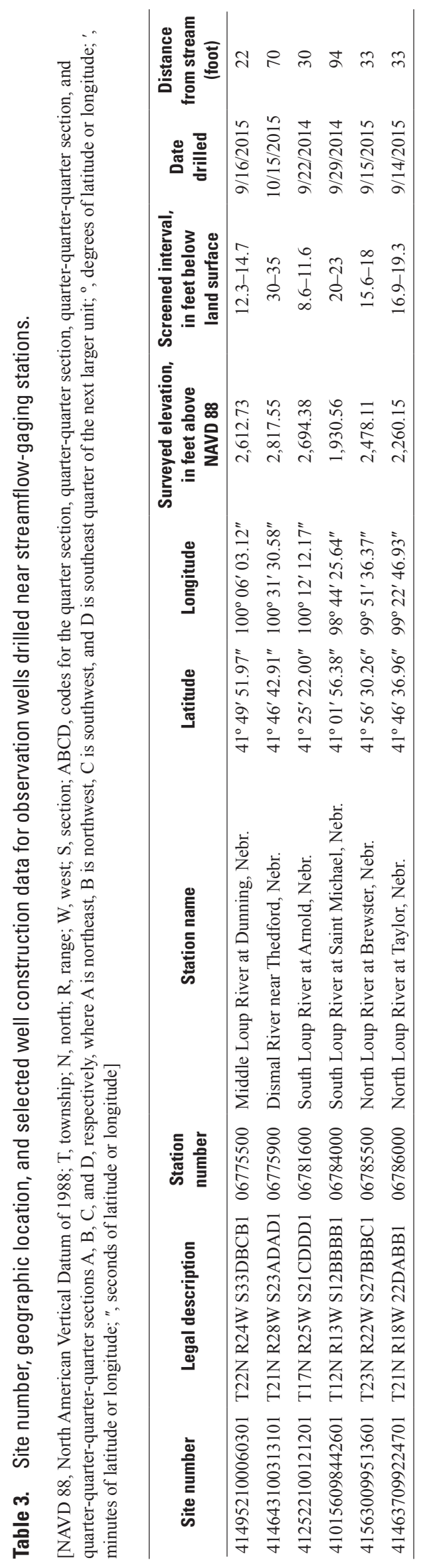


Tcorr is the temperature extracted from the corrected TIR imagery, and

$n \quad$ is the number of locations where temperature comparisons were made.

The RMSE was $0.5^{\circ} \mathrm{C}$ for the South Loup River and $0.4^{\circ} \mathrm{C}$ for the Dismal River, indicating that corrected aerial TIR imagery adequately characterized stream surface temperatures for these streams. The RMSE for the North Loup River was $1.6^{\circ} \mathrm{C}$, the highest for any stream reach as part of this study. The difference in temperature between the self-logging temperature sensor downstream from the diversion dam to the Taylor-Ord Canal (fig. 5) and corrected aerial TIR imagery temperature was approximately $4.2{ }^{\circ} \mathrm{C}$; however, if this one data point is omitted, the calculated RMSE is $0.3^{\circ} \mathrm{C}$. The cause of the large difference in temperature below the diversion dam currently (2018) is unknown. The cause, however, may be from a change in emissivity because of a reduction in the suspended sediment in the North Loup River. Approximately $5 \mathrm{mi}$ downstream from the diversion dam at the Taylor streamflow-gaging station, the temperature difference was $0.4{ }^{\circ} \mathrm{C}$, indicating that this affected only a small area.

\section{Orthorectification}

For this study, the contractor provided the aerial TIR imagery as georeferenced grids (rasters) for interpretation within a geographic information system (GIS) environment. The TIR images were georeferenced (orthorectified) using SimActive 3D Correlator software (SimActive Inc., 2016). SimActive 3D Correlator is a photogrammetric software package designed to orthorectify and mosaic aerial imagery. The temperature-corrected TIR images, USGS 10-meter digital elevation model (Nebraska Department of Natural Resources and U.S. Geological Survey, 1998), and exterior camera orientation data logged by the GPS/inertial measurement unit system were used as data inputs.

Reference imagery was used to provide photograph-identifiable ground control points to help enhance the aerial triangulation solution. For the middle and lower South Loup River (downstream from the Pressey Park recorder well, fig. 3), four-band orthoimages previously collected by the contractor (Cornerstone Mapping, unpub. data, 2015) for other mapping purposes were used as reference images. This set of reference images was collected with a 2-ft GSD. In 2016, the contractor flew 0.98-ft GSD, four-band imagery over the Lower Dismal River and North Loup River several weeks before the TIR imagery acquisition for this study. The horizontal accuracy of the contactor-collected reference imagery was designed to meet the American Society for Photogrammetry and Remote Sensing Class II accuracy standard.

For some stream reaches within the Upper Loup NRD (upper South Loup River and upper Dismal River), the best available reference imagery was U.S. Department of Agriculture, Farm Service Agency (2017). The Farm Service Agency imagery is collected with a 3.28 -ft GSD and a horizontal accuracy of $20 \mathrm{ft}$.
The contractor-supplied imagery was valuable to add temporally valid context with high spatial resolution, which aided thermal image interpretation. Generally speaking, the horizontal accuracy of the orthorectified TIR imagery was within $3 \mathrm{ft}$ of the reference imagery. Measured horizontal accuracies of each individual stream reach are stated in Hobza and Densmore (2018).

\section{Thermal Infrared Imagery Analysis}

Georeferenced TIR imagery was interpreted within a GIS environment using two different analysis methods. The first method involved creating downstream temperature profiles where stream surface temperatures are extracted every $6.6 \mathrm{ft}$ along a digitized stream centerline. The extracted point temperatures were plotted against distance upstream or downstream from a streamflow-gaging station. Because aerial TIR imagery was collected before the onset of ice, warmer stream temperatures would be the result of an increase in the proportion of groundwater discharge, relative to total streamflow. The downstream temperature profiles included parts of the stream that were totally or partially obstructed by bridges and overhanging vegetation, which were generally much cooler than the stream surface. Tree limbs from deciduous trees, which only partially obscure a part of a raster cell, effectively decreased the average apparent temperature, creating a negative bias. First, negative spikes of extracted point temperature data were removed to retain the overall trend of the downstream temperature profile. A seven-point moving average was computed to effectively smooth the downstream temperature profile, minimizing the effect of tree cover for the upper and middle South Loup River and the upper Dismal River.

The second analysis method estimated the density of focused groundwater discharge points along individual stream reaches. The density of focused groundwater discharge points was assessed by creating an Esri shapefile (Esri, 1998) and picking individual focused groundwater discharge points through visual inspection of the TIR and reference imagery. Areas of slightly warmer water along stream margins and within stream channels were marked with points. For each focused groundwater discharge point, the downstream distance along the stream centerline was calculated within a GIS environment. Interpreted focused groundwater discharge points were totaled for each subdivided stream-reach segment. Focused groundwater discharge point density was estimated in number of points per 1,000 or $5,000 \mathrm{ft}$.

This approach, although straightforward and simple to apply, does have limitations. The approach relies solely on visual inspection of aerial TIR imagery and should be regarded as semiquantitative because of the difficulty in determining the precise number of points where groundwater is discharging to the stream. Verification of the interpreted groundwater discharge points would be nearly impossible because of the number of focused groundwater discharge points, length of the reaches studied, landowner permission and coordination needed, and site accessibility. Furthermore, 
the tree and vegetative cover that obscured parts of the stream channel for some streams undoubtedly prevented the detection of some focused groundwater discharge points with aerial TIR imagery. Nevertheless, estimating the density of focused groundwater discharge points and interpreting spatial patterns have provided meaningful interpretations that are discussed in subsequent sections of this report.

\section{Methods Used to Describe Temporal Characteristics of Groundwater Discharge}

Additional water-level and temperature data were collected at six streamflow-gaging stations in 2014, 2015, and 2016 (table 1; fig. 1) to assess the temporal variability of groundwater discharge. The data collection approach, described in Eddy-Miller and others (2012), consists of a streamflow-gaging station coupled with an observation well completed below the elevation of the streambed and instrumented with a water-level recorder. The comparison of continuous groundwater-level elevation and stream-stage elevation can indicate whether a stream is gaining or losing near the streamflow-gaging station. Continuous water temperature was collected in the stream and the shallow observation well to provide further support to groundwater/surface-water interaction trends. The information provided by a network of instrumented streamflow-gaging stations with differing basin and land-use characteristics allows for an analysis of groundwater discharge patterns, temporally and spatially (Eddy-Miller and others, 2012).

Observation well construction and location information is presented in table 3. Observation wells and instrumentation were installed at both South Loup streamflow-gaging stations in September 2014, and the remaining four listed in table 3 were installed in September and October 2015. Five of the observation wells were installed using a tractor-mounted soil coring rig (Model 54TR, Geoprobe Systems, Salina, Kansas). A contractor was hired to install the observation well near the Dismal River streamflow-gaging station because the semiconsolidated sandstone and siltstone would have prevented the tractor-mounted soil coring rig from reaching the target depth. Core sections were collected in 4-ft intervals to depths that extend below the level of the streambed. Observation wells were screened below the bottom of the streambed and were within $100 \mathrm{ft}$ of the streambank (table 3).

The observation wells were instrumented with a KPSI 355 vented pressure transducer (TE Connectivity, 2017) placed near the bottom of the well. Groundwater temperature and stream temperature data were collected with a pair of $\mathrm{H}-377$ Design Analysis water temperature sensors (Design Analysis Associates, Inc., 2017). The groundwater temperature sensor was attached to the cable just above the transducer at the bottom of the well. The stream temperature sensor was installed within a well-mixed part of the stream. All water-level and temperature data were collected following the protocols and guidance stated in Cunningham and Schalk (2011), Turnipseed and Sauer
(2010), and Wagner and others (2006) and are stored in the NWIS database (U.S. Geological Survey, 2017).

In order to compare measured groundwater and surfacewater levels at the same datum, elevations were surveyed using the Global Navigation Satellite Systems (GNSS) followed by a series of station levels (Kenney, 2010) to tie the GNSS-recorded elevation to the streamflow-gaging station datum. Static GNSS surveys involved collecting positioning data by setting up a GNSS receiver antenna over a benchmark cap set into the concrete well pad. A Trimble R8 (Trimble Navigation Limited, 2009) GNSS receiver antennae collected measurements from positioning satellites for at least 4 hours at each observation well (Rydlund and Densmore, 2012). The GNSS data collected during static surveys were postprocessed later with data collected from nearby control stations to correct atmospheric interference errors and to produce survey-grade solutions. After each static-survey session, the logged data file was sent to the Online Positioning User Service (OPUS; https://www.ngs.noaa.gov/OPUS/) to determine the exact position of the surveyed test hole. OPUS is a quality-assured service provided by the National Geodetic Survey where users can process single-base GNSS data through an online-user interface. OPUS processes logged data using continuously operating reference stations. The accuracy of the solutions was reported as peak-to-peak errors, which represent the difference between maximum and minimum values of the coordinates obtained from the three baseline solutions (Rydlund and Densmore, 2012). Generally speaking, the vertical peak-to-peak errors were less than 1 in., indicating that coordinates for all surveyed points met the criteria for USGS Level II single-base Online Positioning User Service-Static (OPUS-S) survey accuracy (Rydlund and Densmore, 2012).

Station levels were completed to tie the established streamflow-gaging station datum to the surveyed benchmark elevation at the concrete well pad. Station levels were completed using a Sokkia SDL30 (Sokkia Topcon Co., Ltd., 2000) electronic digital level system in accordance with the guidelines and procedures stated in Kenney (2010).

\section{Groundwater Discharge Characteristics for Streams in the Loup River Basin}

This section describes the groundwater discharge characteristics of selected reaches of the South Loup, Dismal, and North Loup Rivers. The spatial characteristics were studied using a combination of stream reconnaissance at selected locations followed by an analysis of aerial TIR imagery. Temporal characteristics were described by examining continuous water-level and stream temperature data at six streamflowgaging stations within the Loup River Basin. Interpretations and descriptions of the spatial and temporal characteristics are presented together for each stream studied. 


\section{South Loup River and North Fork South Loup River}

Stream reconnaissance data were collected at selected locations along the South Loup River during August 2014 and 2015 (fig. 3). Based on stream reconnaissance data and field observations, the South Loup River is divided into three reaches. The upper South Loup River, which includes the 4-mi reach of the North Fork South Loup River, extends 36 mi to the South Loup River at Arnold, Nebr., streamflow-gaging station (USGS station 06781600; hereinafter referred to as the "Arnold streamflow-gaging station;" fig. 3). The middle South Loup River is a 62-mi reach, which extends from the Arnold streamflow-gaging station to immediately downstream from the Pressey Park recorder well (fig. 3), and the lower South Loup River is a 94-mi reach, which extends from the Pressey Park recorder well to the Saint Michael streamflow-gaging station (fig. 3; table 3). Spatial and temporal characteristics of groundwater discharge for each stream reach are described in the following subsections.

\section{Upper South Loup River and North Fork South Loup River}

Streamflow measurements collected in August 2014 and 2015 along the upper South Loup River indicate a gradual increase in streamflow throughout the 36-mi reach (table 2; fig. 7). Because of backwater conditions at the mouth, the streamflow of the North Fork South Loup River was estimated by calculating the difference in streamflows immediately above and below the confluence. The estimated flow of the North Fork South Loup River was 7.2 cubic feet per second $\left(\mathrm{ft}^{3} / \mathrm{s}\right)$, which was more than twice the flow of the South Loup River above the confluence. At the time the streamflow measurements were collected (August 2015), the North Fork South Loup River provided approximately 40 percent of the flow measured at Arnold streamflow-gaging station. Because the confluence is away from county roads, the North Fork South Loup was not measured in the 2006 seepage run (Peterson and Strauch, 2007). Though each set of measurements was collected 1 year apart, they likely are comparable between years because the median daily flows measured at the Arnold streamflow-gaging station during the stream reconnaissance were within $2 \mathrm{ft}^{3} / \mathrm{s}\left(19.2 \mathrm{ft}^{3} / \mathrm{s}\right.$ in 2014 and $17.8 \mathrm{ft}^{3} / \mathrm{s}$ in 2015).

Potentiomanometer measurements indicate locally variable vertical hydraulic gradients that ranged from -0.06 to 0.26 foot per foot (ft/ft; table 4 ). The median vertical hydraulic gradient was $0.01 \mathrm{ft} / \mathrm{ft}$, which was consistent with measured streamflow (table 4), indicated gaining conditions. In general, streambed temperatures were slightly cooler than the mean stream temperature (table 4). Although streambed temperatures were cooler than the stream temperature, which indicates groundwater discharge through the streambed, the streambed temperature still was much warmer than the ambient shallow groundwater temperature $\left(11\right.$ to $14^{\circ} \mathrm{C}$; U.S. Geological
Survey, 2017). This difference in temperature indicates that discharged groundwater mixes with stream water within the hyporheic zone.

Aerial TIR imagery indicated numerous small, focused groundwater discharge points along the margins of the upper South Loup River (fig. 8A) and North Fork South Loup River (fig. $8 B$ ). In some locations, the South Loup River appears to flow through wet meadows where shallow groundwater is discharging into the stream emanating from many focused points. The downstream temperature profiles, derived from aerial TIR imagery for the South Loup River and North Fork South Loup River above the Arnold streamflow-gaging station are shown in figure 9. The North Fork South Loup River is warmer than the South Loup River, indicating flow is sustained by recently discharged groundwater. Generally speaking, the temperature of headwater streams is closer to the local groundwater temperatures compared to larger order streams (Caissie, 2006). Increases in stream temperature on the South Loup River, measured along a 10-mi reach centered on the confluence with the North Fork South Loup River (fig. 9), indicate the stream is receiving additional groundwater discharge along this reach.

The concentration of focused groundwater discharge points along the South Loup River is shown as blue symbols in figure 7. Focused groundwater discharge on the upper South Loup River tended to be clustered. The density of focused groundwater discharge points of the North Fork South Loup River generally was higher and appeared to decrease moving downstream to the mouth of the South Loup River. The volume of water produced from this dense network of focused groundwater discharge points along the North Fork South Loup River is sufficient to provide approximately 40 percent of the flow measured at the Arnold streamflow-gaging station during the irrigation season.

Geologic maps (Souders, 2000) and test holes (Conservation and Survey Division, University of Nebraska-Lincoln, 2017a) indicate the upper South Loup River has incised into a mix of Quaternary eolian silt and fine-grained sand. The streambed of the upper South Loup River contains some interbedded silt that can restrict the vertical movement of groundwater to the stream, which can result in large hydraulic gradients. Groundwater discharge within the upper South Loup River and North Fork South Loup River is dominated by focused groundwater discharge emanating at many points near the stream margin.

The groundwater levels measured near the Arnold streamflow-gaging station (fig. 3; table 3) were higher than stream-level elevations, indicating gaining conditions (fig. 10A). Changes in groundwater elevation track closely to the stream elevation, indicating a high degree of connectivity between the stream and shallow groundwater. Groundwater temperature measured in the shallow well displays an annual temperature cycle that varies between 7.5 and $14.5^{\circ} \mathrm{C}$ (fig. 10B). The annual maximum was measured in early fall, and its annual minimum was in early spring. The annual minimum and maximum groundwater temperatures lag behind the annual minimum and maximum stream and, by inference, 


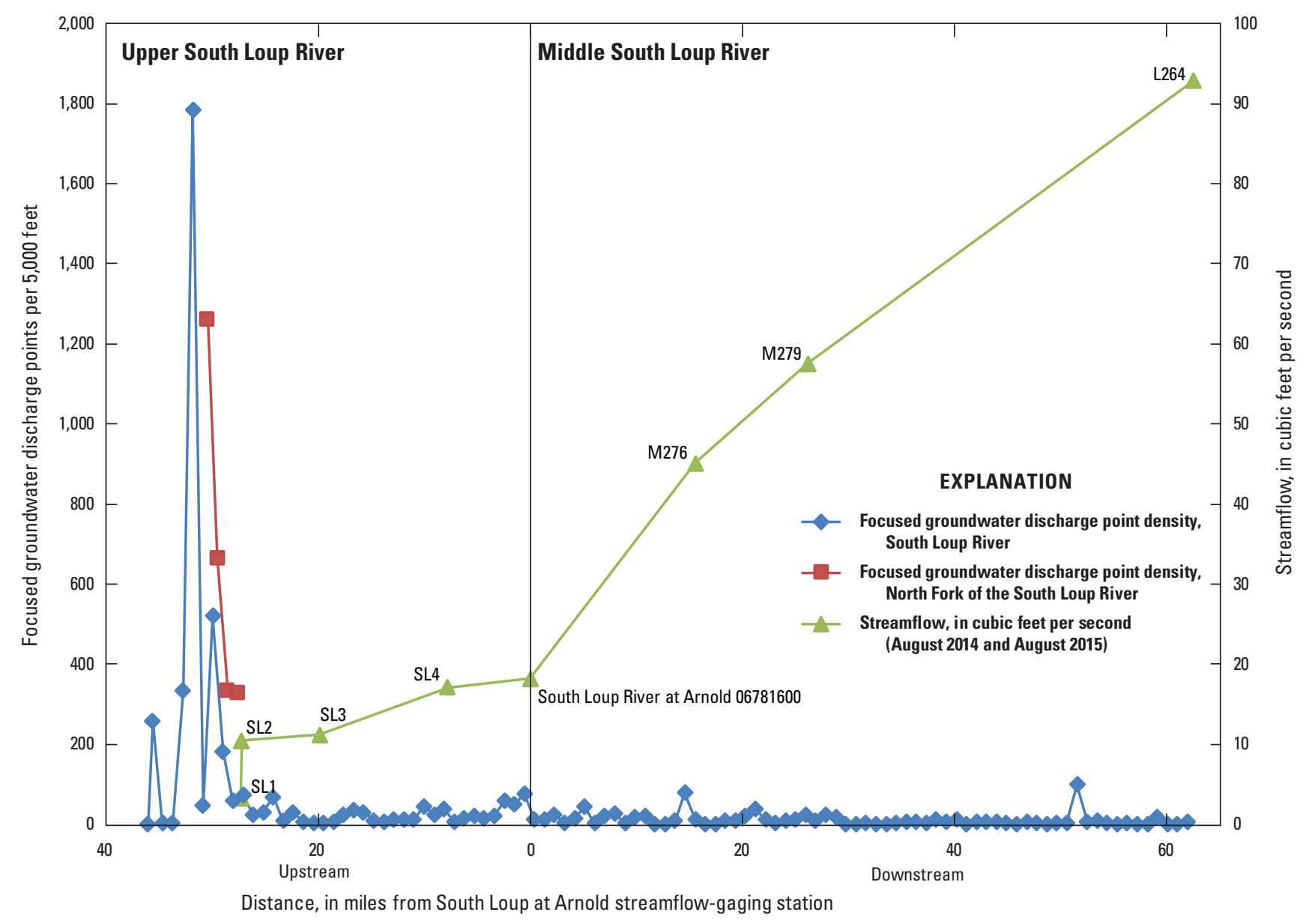

Figure 7. Measured streamflow and the estimated density of focused groundwater discharge points along the upper and middle South Loup River reaches and North Fork South Loup River.

air temperatures. Because the stream is gaining consistently in this location, and the direction of groundwater movement is towards the stream, the changes in groundwater temperature are in response to heat transfer through thermal conduction from surface heating and cooling.

\section{Middle South Loup River}

Streamflow measurements along the 62-mi reach of the middle South Loup River indicated substantial increases in groundwater discharge (fig. 7; table 2). Based on discharge measurements from August 26, 2015, streamflow increased from $17.8 \mathrm{ft}^{3} / \mathrm{s}$ at the Arnold streamflow-gaging station (U.S. Geological Survey, 2017) to $92.8 \mathrm{ft}^{3} / \mathrm{s}$ near the Pressey Park recorder well (table 2; fig. 3). In general, streambed temperatures were cooler along the middle South Loup River compared to the upper South Loup River (table 4). Some measured streambed temperatures were cool enough that they approached ambient groundwater temperatures (U.S. Geological Survey, 2017), indicating vertical movement of groundwater through the streambed with little to no mixing of surface water within the hyporheic zone. The streambed texture changes below the Arnold streamflow-gaging station from a silty very fine sand to medium to coarse sand. An active sand and gravel mining operation is at the margin of the South Loup River approximately 3 mi downstream from the Arnold streamflow-gaging station.

The aerial TIR imagery acquired along the middle South Loup was collected over two flights on November 23-24 and December 2-3, 2015. TIR imagery was collected with a 1.64$\mathrm{ft}$ resolution for the upper $44 \mathrm{mi}$ and with a 3.28 - $\mathrm{ft}$ resolution for the lower $18 \mathrm{mi}$ (table 2; fig. 3). The downstream temperature profile for the middle South Loup River is shown in figures 11 and 12. The downstream temperature profile indicates a substantial increase in stream temperature starting approximately $5 \mathrm{mi}$ below the Arnold streamflow-gaging station (fig. 11), which is the result of increased groundwater discharge. Stream temperatures peaked approximately $7 \mathrm{mi}$ downstream from the Arnold streamflow-gaging station before colder air temperatures decreased stream temperatures. Streamflow measurements indicate increases in streamflow through the 62-mi middle South Loup reach from groundwater discharge (table 2); however, decreases in stream temperature result from the fact that the additional warmer groundwater discharge constitutes a smaller proportion of total streamflow. 


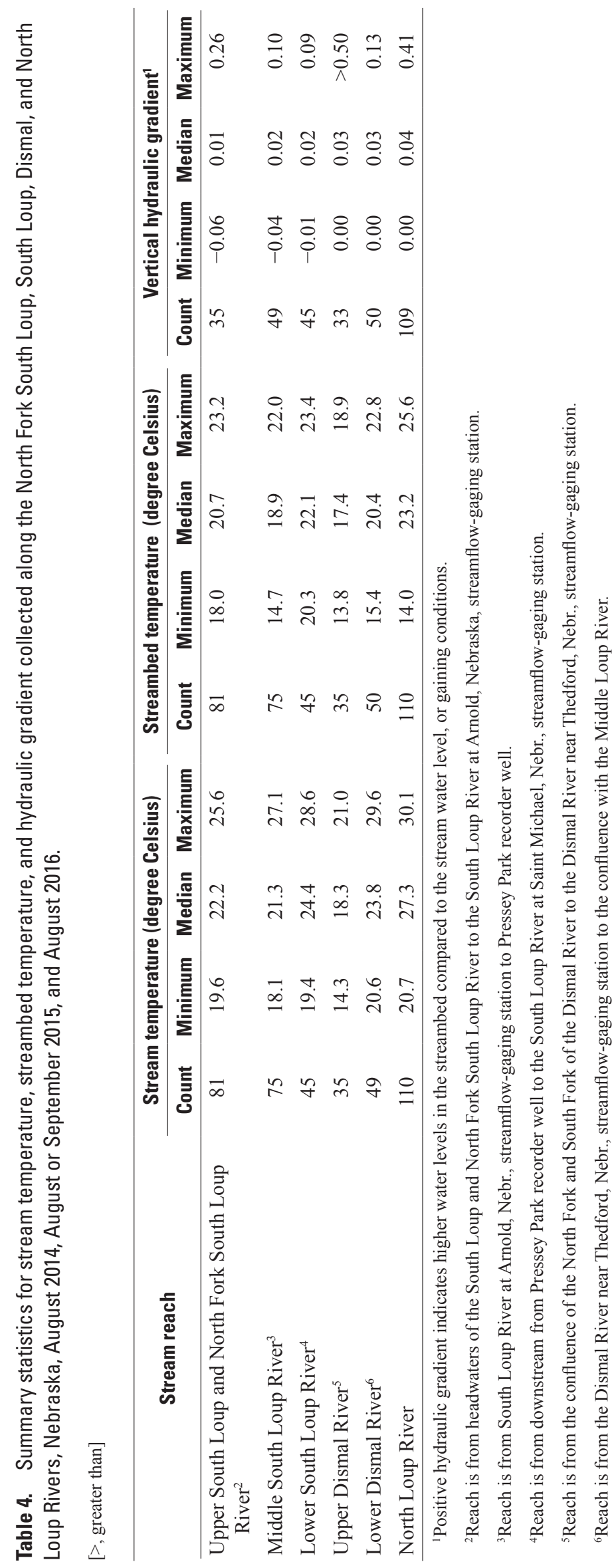




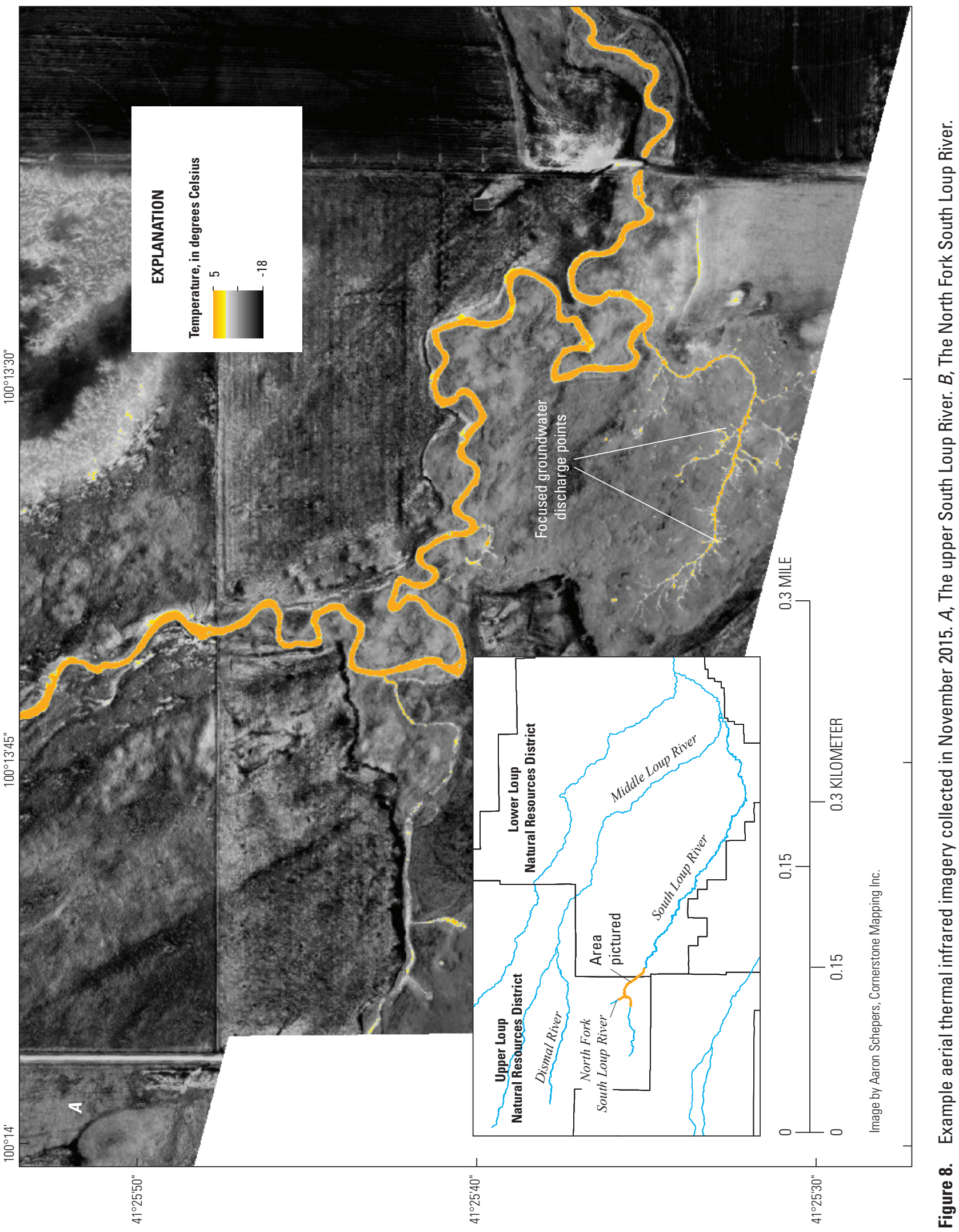




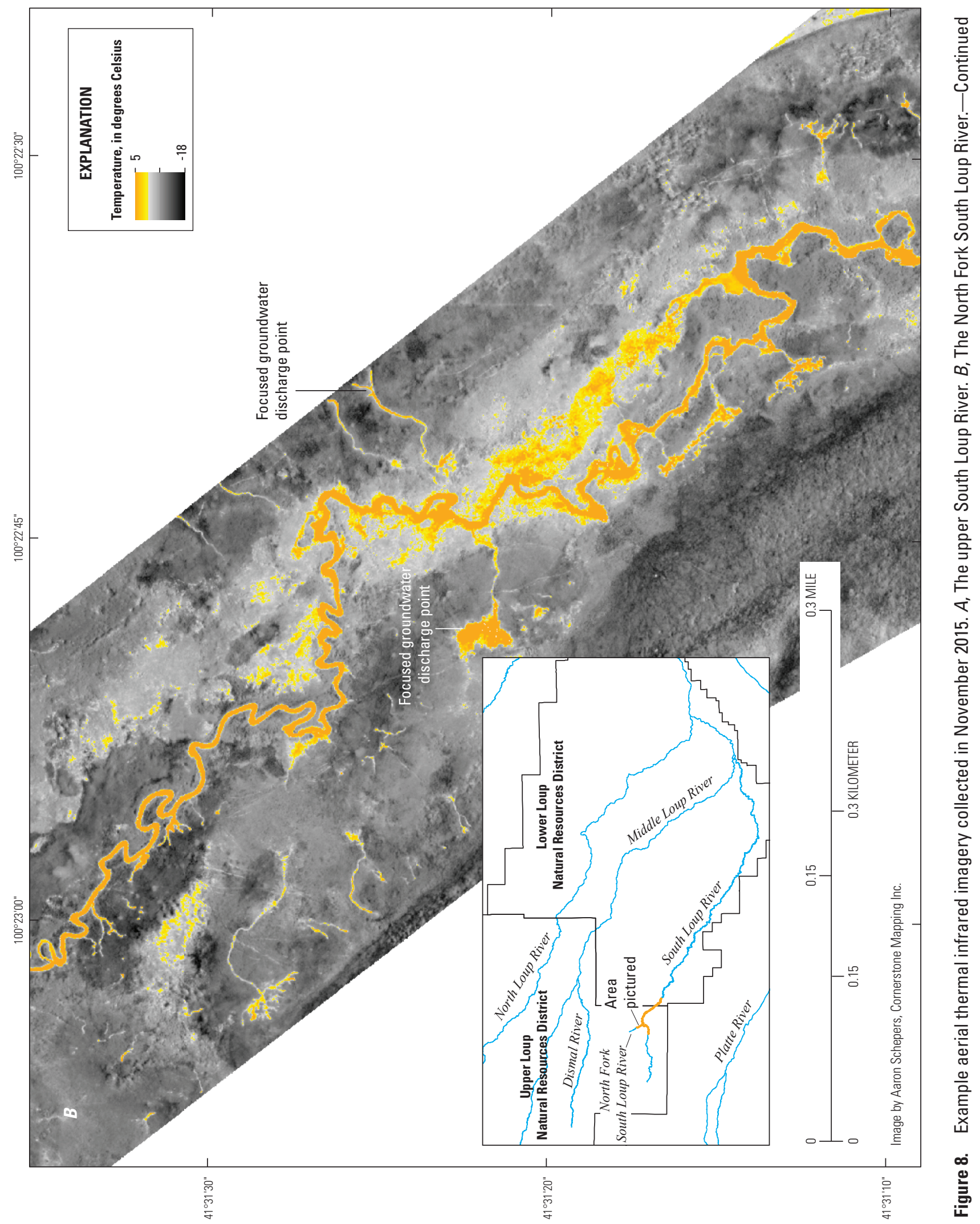




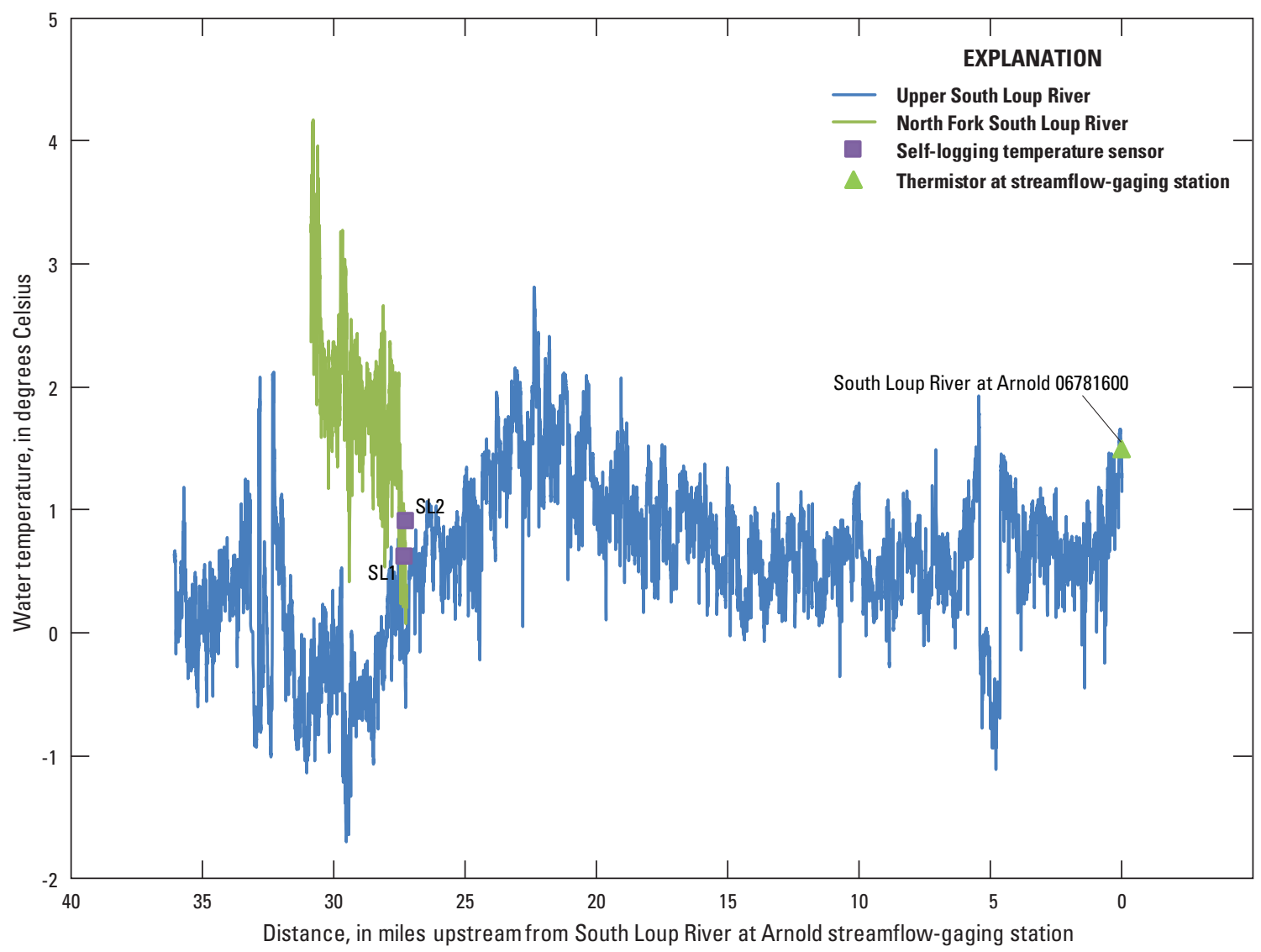

Figure 9. Downstream temperature profiles of the upper South Loup River and the North Fork South Loup River, above the South Loup River at Arnold, Nebraska, streamflow-gaging station. Downstream temperature profiles were created from aerial thermal infrared imagery collected December 2-3, 2015.

The middle South Loup River, 5 mi below the Arnold streamflow-gaging station, incises into a Pliocene-age gravel (Conservation and Survey Division, University of NebraskaLincoln, 2017a; Souders, 2000), which increases the groundwater discharge to the stream. The upper South Loup River, which was dominated by focused groundwater discharge, transitions to a reach dominated by diffuse groundwater discharge through the streambed as the texture grades from silt and fine-grained sand to a more permeable medium to coarse sand and fine gravel.

Several large focused groundwater discharge points were observed in the aerial TIR imagery along the stream margin between the Arnold streamflow-gaging station and the Pressey Park recorder well (fig. 3). Some of these focused groundwater discharge points appeared to be up to $75 \mathrm{ft}$ across. Other focused groundwater discharge points appeared to be in sandpits from former sand and gravel mining operations where the overlying finer-grained Quaternary sediments were removed (fig. 13). The aerial TIR-based temperature of the focused groundwater discharge points exceeded $4.5^{\circ} \mathrm{C}$. Because of their size and location, these focused groundwater discharge points appear to be prominent hydrologic features.

In September 2017, several of these groundwater discharge points were selected for ground verification and visual inspection. Some focused groundwater discharge points appeared to have merged from draws that lead to the South Loup River (fig. 13). The temperature of the discharged groundwater measured was as low as $13.0^{\circ} \mathrm{C}$, which is close to the ambient regional groundwater temperature. Groundwater appears to flow from coarse sand to coarse gravel at many points within open bowl-shaped depressions (figs. 14A and 14B). Discharge from individual groundwater discharge points was variable but was estimated to be as much as $1.5 \mathrm{ft}^{3} / \mathrm{s}$. The formation of these focused groundwater discharge points appears to be the product of groundwater sapping. With time, the constant flow from focused groundwater discharge has removed finer-grained sediments, leaving coarser-grained sediments behind. Headward erosion seems to have increased the size and discharge of the focused groundwater discharge points, which created the bowl-like depressions that abruptly end at hillsides (figs. $14 A$ and $14 B$ ).

Diffuse groundwater discharge appears to dominate the lower end of the middle South Loup River. A recorder well was instrumented in spring 2014 to record groundwater levels from the Ogallala (USGS station 411126099422501; U.S. Geological Survey, 2017). In July 2017, as this report was being prepared, a streamflow-gaging station was installed on the South Loup River, near the Pressey Park recorder 

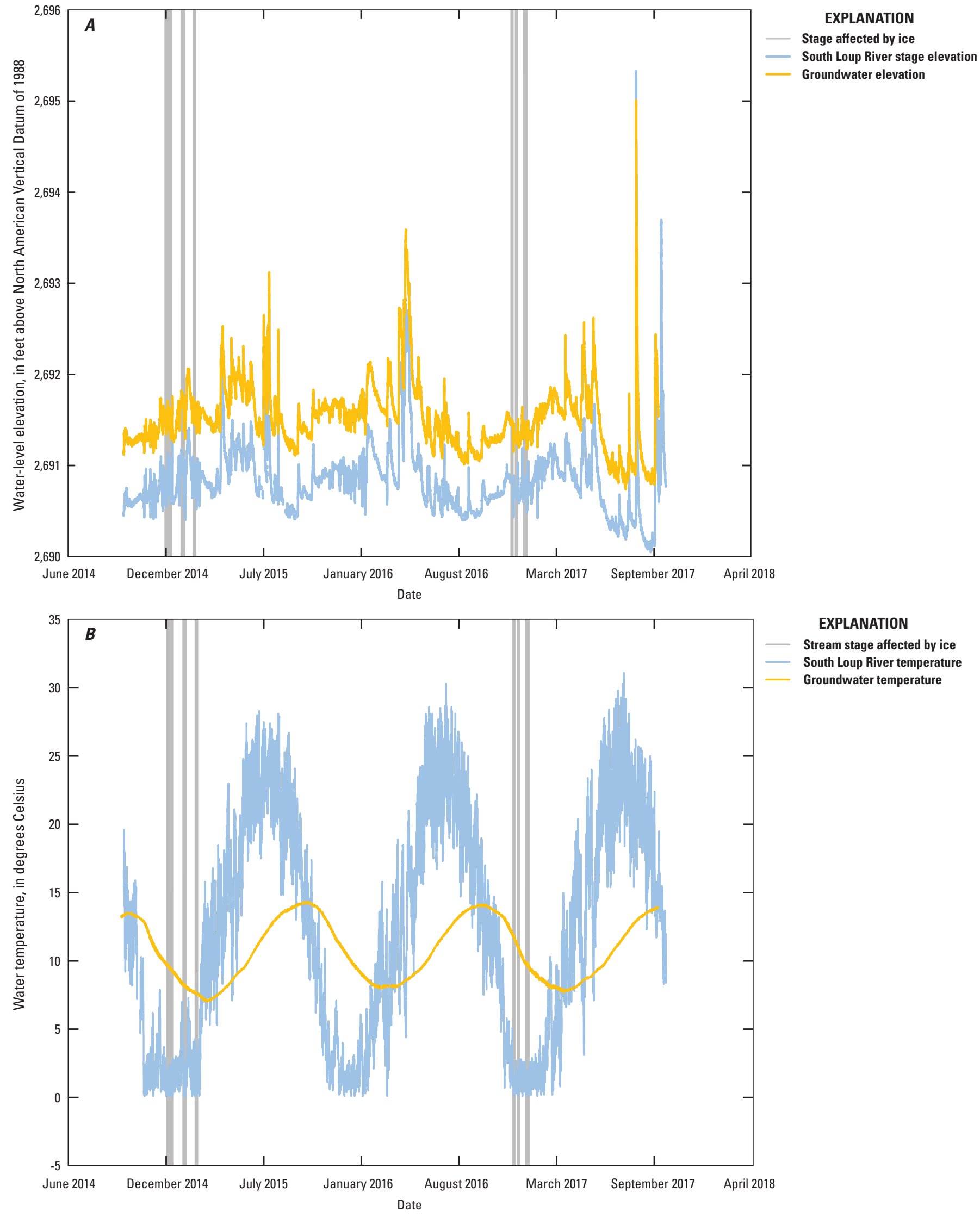

Figure 10. South Loup River at Arnold, Nebraska, streamflow-gaging station (U.S. Geological Survey station 06781600) and nearby observation well. $A$, Stream and groundwater-level elevation. $B$, South Loup River and groundwater temperature. 


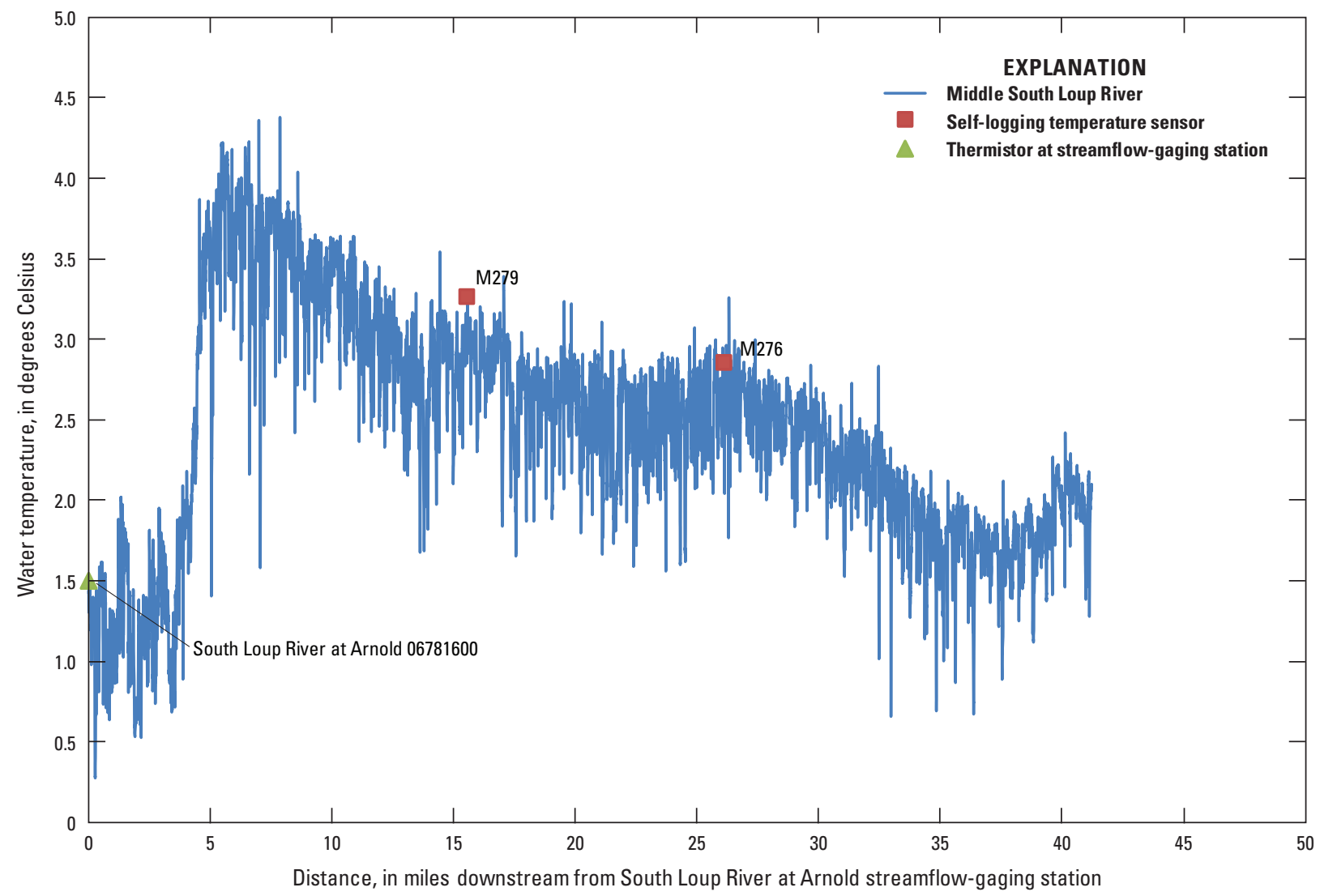

Figure 11. Downstream temperature profile for the middle South Loup River created from aerial thermal infrared imagery collected December 2-3, 2015.

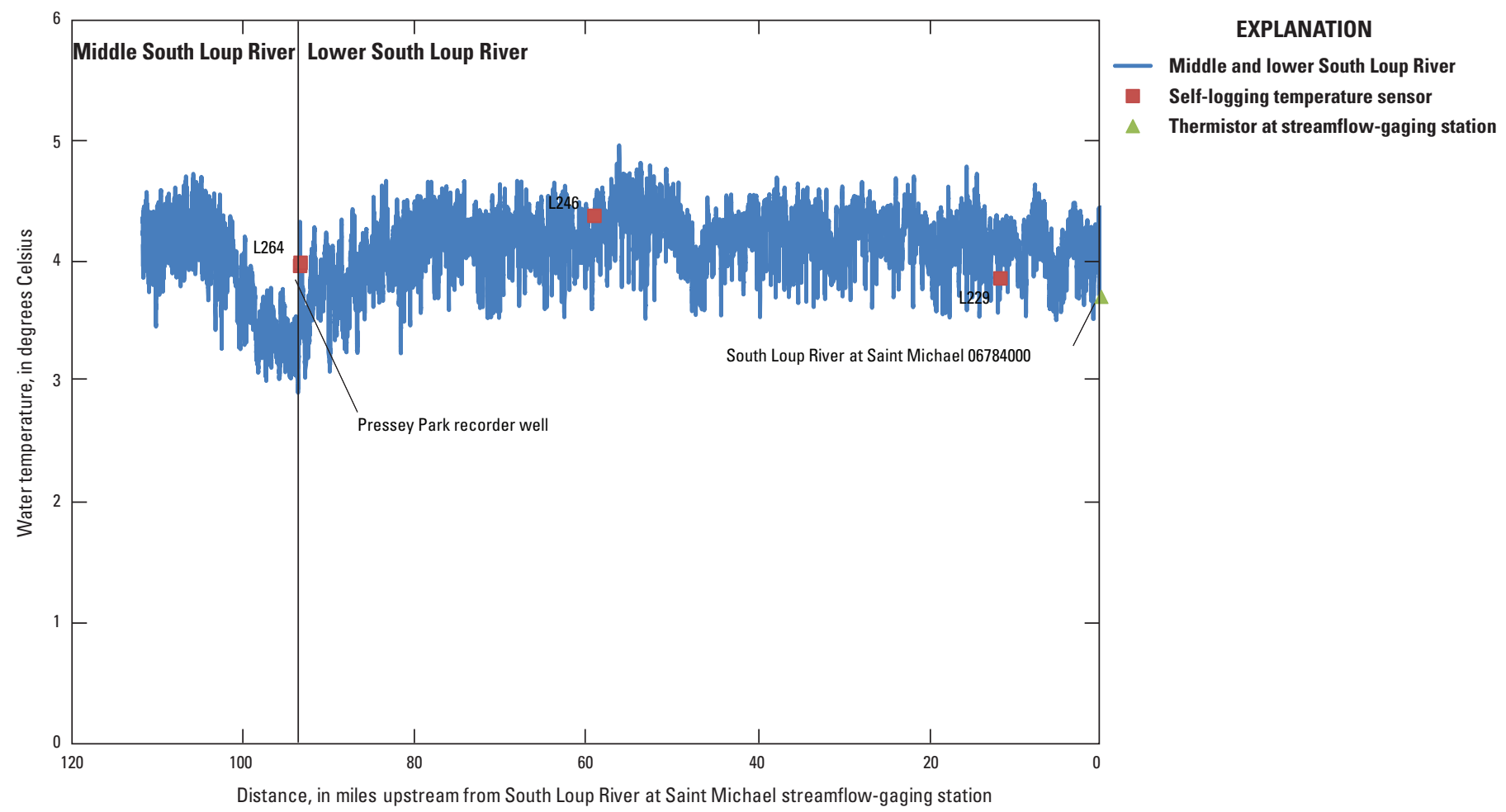

Figure 12. Downstream temperature profile for the middle and lower South Loup River created from aerial thermal infrared imagery collected November 23-24, 2015. 


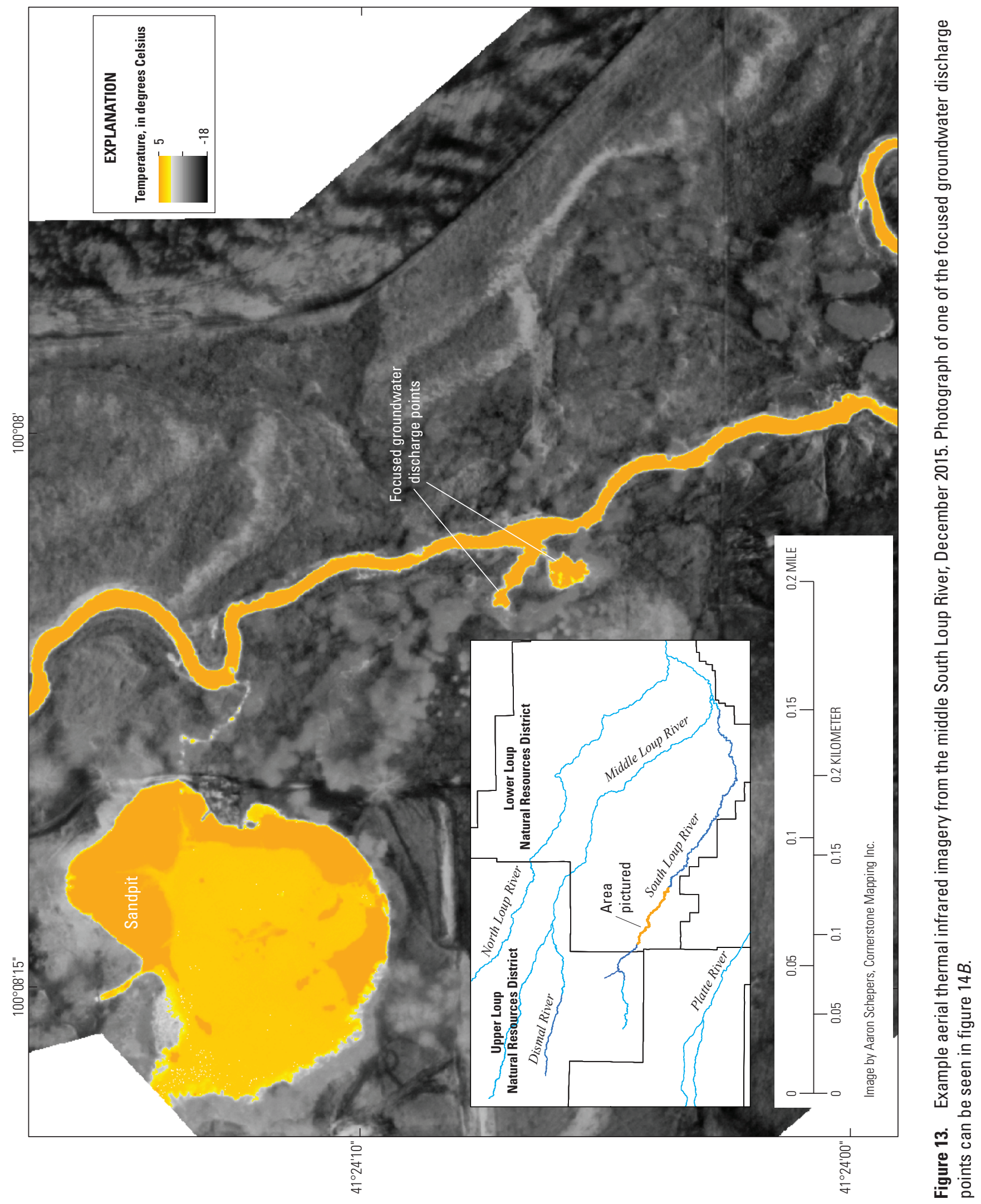



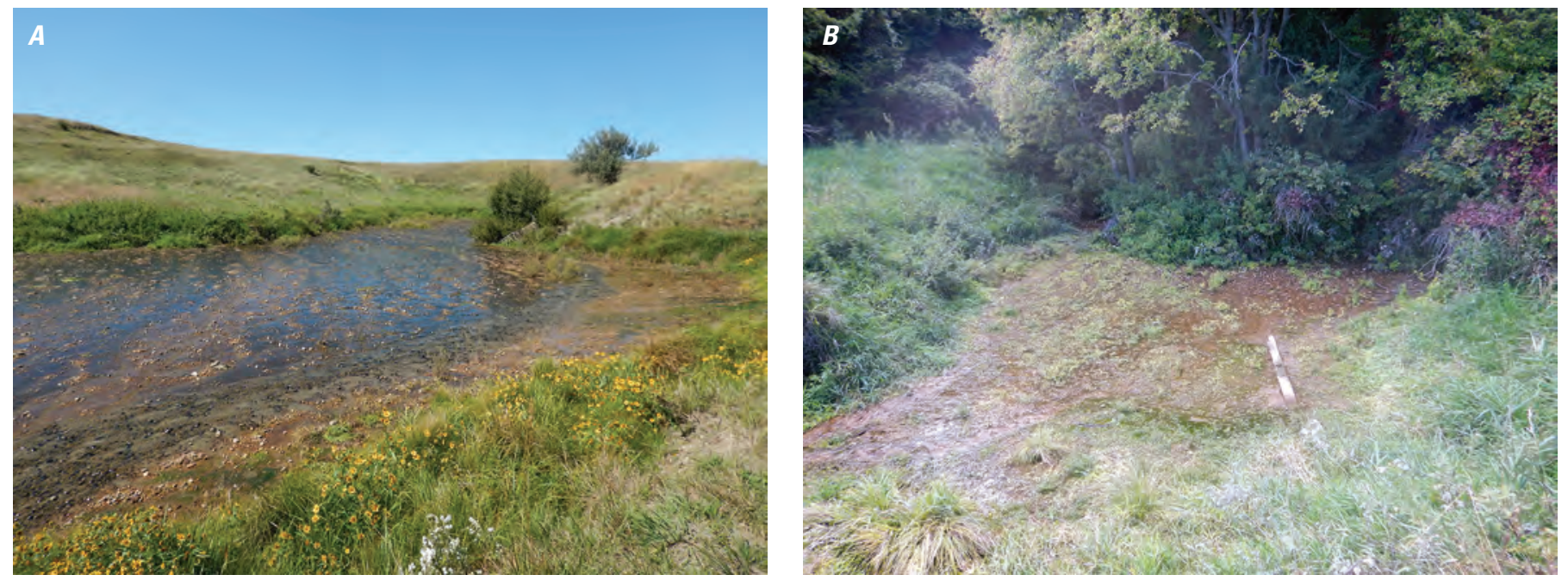

Figure 14. Two focused groundwater discharge points along the middle South Loup River. $A$, The location is approximately 7 miles southeast of the South Loup River at Arnold, Nebraska, streamflow-gaging station (U.S. Geological Survey station 06781600). B, Aerial thermal infrared image displaying focused groundwater discharge point can be seen in figure 13 and is approximately 4 miles southeast of the South Loup River at Arnold, Nebr., streamflow-gaging station.

well (fig. 3; USGS station 06781900; U.S. Geological Survey, 2017). Comparison of groundwater levels indicates that groundwater from the Ogallala is discharging through the overlying Quaternary alluvial aquifer into the South Loup River. Steep drops in water levels associated with pumping were recorded from late May through September. Other times of the year, during ambient or nonpumping conditions, the hydraulic gradient is approximately $0.05 \mathrm{ft} / \mathrm{ft}$, which indicates groundwater discharges from the Ogallala to the stream (fig. 15). Streambed temperatures as low as $14.7^{\circ} \mathrm{C}$ were recorded during the stream reconnaissance along the streambank nearest to the recorder wells. The interpretation that this is an area of increased groundwater discharge is consistent with the aerial TIR imagery, which indicated a slight increase in downstream temperature at the Pressey Park recorder well (fig. 12).

\section{Lower South Loup River}

The lower South Loup River begins immediately below Pressey Park and extends 94 mi downstream to the Saint Michael streamflow-gaging station (fig. 3). Stream reconnaissance data indicate that the lower South Loup River receives less groundwater discharge compared to upstream reaches. Streamflow measurements collected in August 2015 indicate that the stream was either neutral or losing throughout its reach (fig. 16). Stream and streambed temperatures were warmer compared to upstream reaches. The minimum streambed temperature was $20.3{ }^{\circ} \mathrm{C}$ (table 4), which indicates the mixing of groundwater with surface water within the hyporheic zone.

Aerial TIR imagery was collected November $23-24$, 2015, at a 3.28-ft spatial resolution (table 2; fig. 3). The downstream temperature profile (fig. 12) displayed little temperature variation along the reach. Focused groundwater discharge points are within the reach but at lower densities compared to the upper and middle South Loup River reaches (fig. 16).

The temporal variability of groundwater discharge along the South Loup River varied with location and season. Streamflow measurements collected during the stream reconnaissance indicate an increase in streamflow within the upper and middle South Loup River reaches. The measured streamflow for much of the lower South Loup River remains relatively constant to the Saint Michael streamflow-gaging station. Peterson and Strauch (2007) reported streamflow measurements collected in late fall 2006 that indicated increasing streamflows along the length of the South Loup River. At the Saint Michael streamflow-gaging station, flows in late summer (table 2; fig. 16) were much lower compared to flows measured in late fall (Peterson and Strauch, 2007). This difference in flow is largely attributed to increases in groundwater pumping and evapotranspiration reducing the groundwater discharge received by the lower South Loup River.

The groundwater levels measured near the Saint Michael streamflow-gaging station indicate seasonally variable groundwater discharge conditions (figs. 17A and 17B). During the spring and early summer (March through June), the groundwater-level elevation is higher than the stream elevation, indicating gaining conditions. Later in the summer (July through August), stream elevations are higher than the groundwater elevation because of increased evapotranspiration and groundwater pumping. This condition continues into the fall until groundwater levels are able to recover. Gaining conditions are assumed to continue into the early spring; however, it is difficult to make this determination with continuous water levels alone because the gage-height record is affected by ice conditions. Ice cover can increase the backpressure 


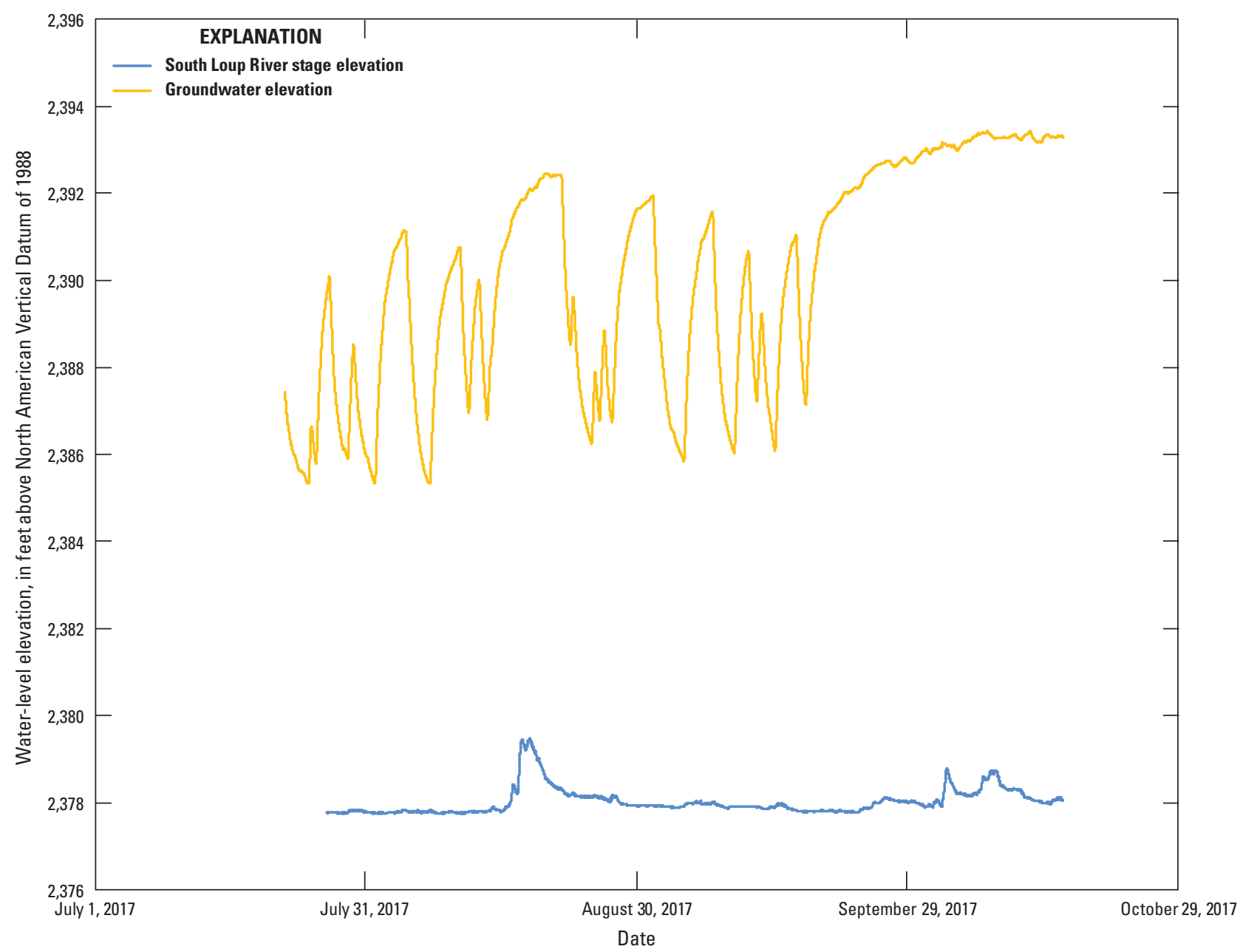

Figure 15. Groundwater-level elevation in the South Loup River at the Pressey Park recorder well and nearby streamflowgaging station (installed July 2017).

measured by the streamflow-gaging station, which can give the impression that the stream is losing flow to the shallow aquifer. An example of this was during December 2016 through January 2017, when stream-stage elevation remained above the groundwater-level elevation, although groundwater demands are minimal during the winter. As stream temperatures warmed and ice cover was eliminated, stream stage dropped below the groundwater-level elevation, indicating gaining conditions.

The groundwater temperature measured in the shallow well displays a cyclical pattern that varies between 11 and $13.5^{\circ} \mathrm{C}$, where its annual maximum is measured in early fall and its annual minimum is in early spring (fig. 17B). Similar to what was measured in the observation well near the Arnold streamflow-gaging station, the annual minimum and maximum groundwater temperatures lag behind the annual minimum and maximum stream temperatures. The annual temperature variation is much less than the observation well near the Arnold streamflow-gaging station, likely because the depth of the well is greater and, therefore, affected less by surface temperatures.

\section{Dismal River}

The 75-mi study reach of the Dismal River extends from the confluence of the North and South Forks of the Dismal River to its mouth on the Middle Loup River (fig. 4). The study reach of the Dismal River was divided into two reaches at the streamflow-gaging station near Thedford, Nebr. (fig. 4). The Dismal River streamflow-gaging station was chosen as a dividing point between the upper and lower reaches because the groundwater discharge characteristics of each reach are considerably different. These characteristics are described in the following subsections.

\section{Upper Dismal River}

Streamflow measurements collected during the stream reconnaissance indicate increasing streamflow throughout the study reach (fig. 18; table 2), which is consistent with streamflow measurements reported in Peterson and Strauch (2007). Focused groundwater flow emanating from springs and vertical conduits (Guhman and Pederson, 1992) helps maintain 


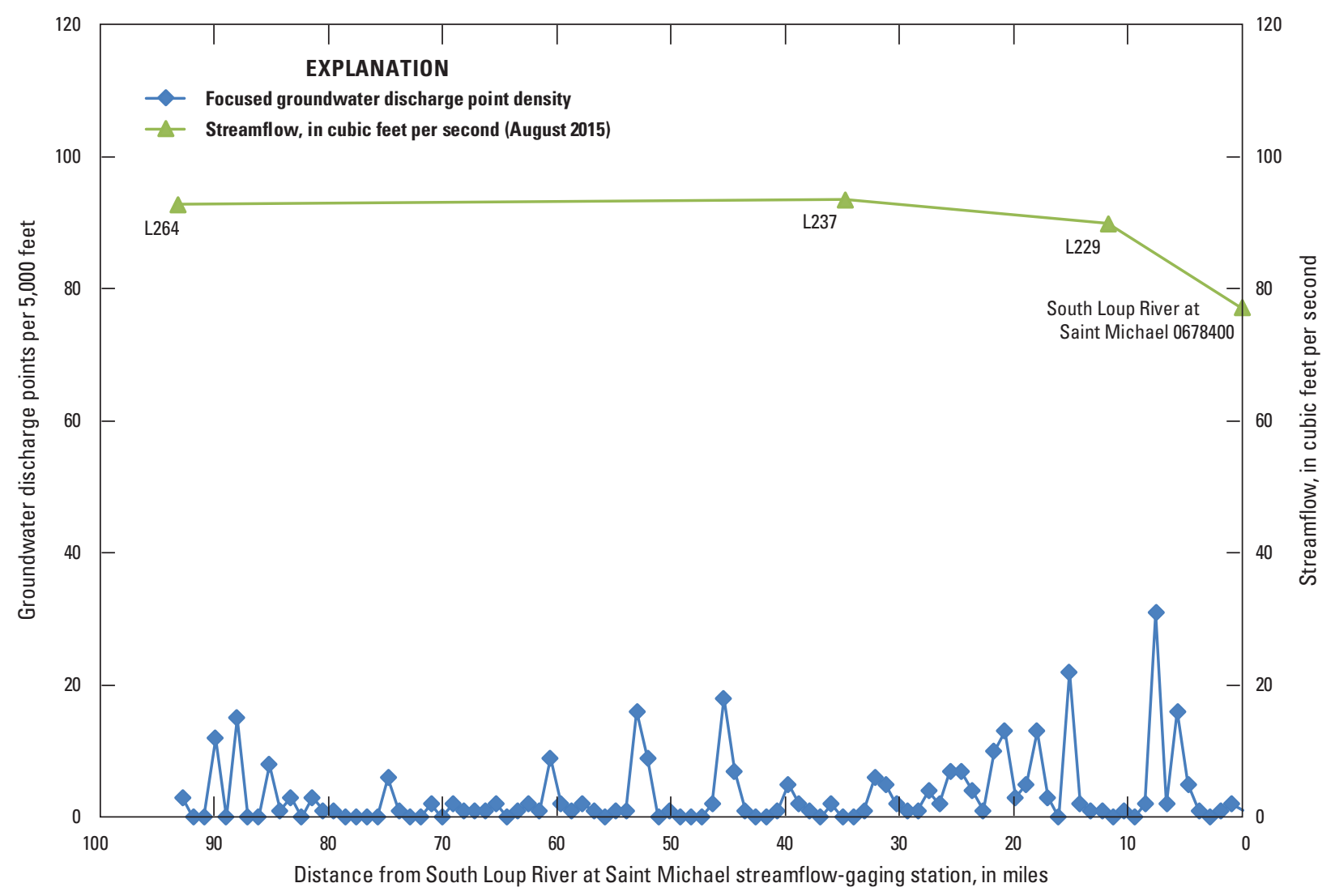

Figure 16. Measured streamflow and the estimated density of focused groundwater discharge points along the lower South Loup River.

a relatively constant temperature compared to other stream reaches studied. The median stream temperature measured during the stream reconnaissance was $18.3^{\circ} \mathrm{C}$, which is less than $1{ }^{\circ} \mathrm{C}$ greater than the median streambed temperature (table 4 ). The minimum streambed temperature was $13.8^{\circ} \mathrm{C}$ (table 4), which is within the expected range of the ambient groundwater temperature, indicating that there is vertical movement of groundwater through the streambed in some locations, and little to no mixing of surface water within the hyporheic zone.

Potentiomanometer measurements collected within the streambed indicated substantial variability in vertical head gradients across short distances. The active stream channel of the Dismal River is incising into the Pliocene deposits, which are locally characterized as fine-grained sand and sandstone interbedded with siltstone. Some points of focused discharge along the upper Dismal River are the result of local confining beds of siltstone, which create strong vertical gradients near the stream margin and can concentrate groundwater discharge to other parts of the stream. Potentiomanometer measurements indicated the lateral persistence of the confining beds is variable, even within short distances. The largest head gradients measured in this study were approximately $50 \mathrm{ft}$ downstream from the Dismal River streamflow-gaging station (fig. 4), near the left bank where the vertical head gradient exceeded
$0.5 \mathrm{ft} / \mathrm{ft}$ (table 4), which is similar to vertical head gradients measured by Guhman and Pederson (1992). At this location, the measured streambed temperature was $18.7^{\circ} \mathrm{C}$, which is close to the median stream temperature (table 4 ), indicating that there is little groundwater discharge through the streambed at this location. The restriction in vertical flow results in the high vertical head gradient measured with the potentiomanometer. On the right bank, the measured streambed temperature was $14.1^{\circ} \mathrm{C}$, which indicates the vertical movement of groundwater through a more permeable streambed. The measured vertical head gradient was an order of magnitude lower $(0.07 \mathrm{ft} / \mathrm{ft})$, which provides further support to this interpretation.

As part of the stream reconnaissance, a spring inventory was completed on the upper Dismal River in early September of 2015. The inventory involved floating the stream reach through private land in a kayak and taking photographs of each visible groundwater discharge point with a GPS-enabled digital camera. Examples can be seen in figures $19 A-C$. Data collection was limited during the spring inventory because landowner access was denied through much of the reach; however, locations were recorded and visual estimates of discharge were made. Most points of focused groundwater discharge typically were small (less than $0.1 \mathrm{ft}^{3} / \mathrm{s}$ ); however, a few focused discharge points into the Dismal River exceeded $2 \mathrm{ft}^{3} / \mathrm{s}$. 


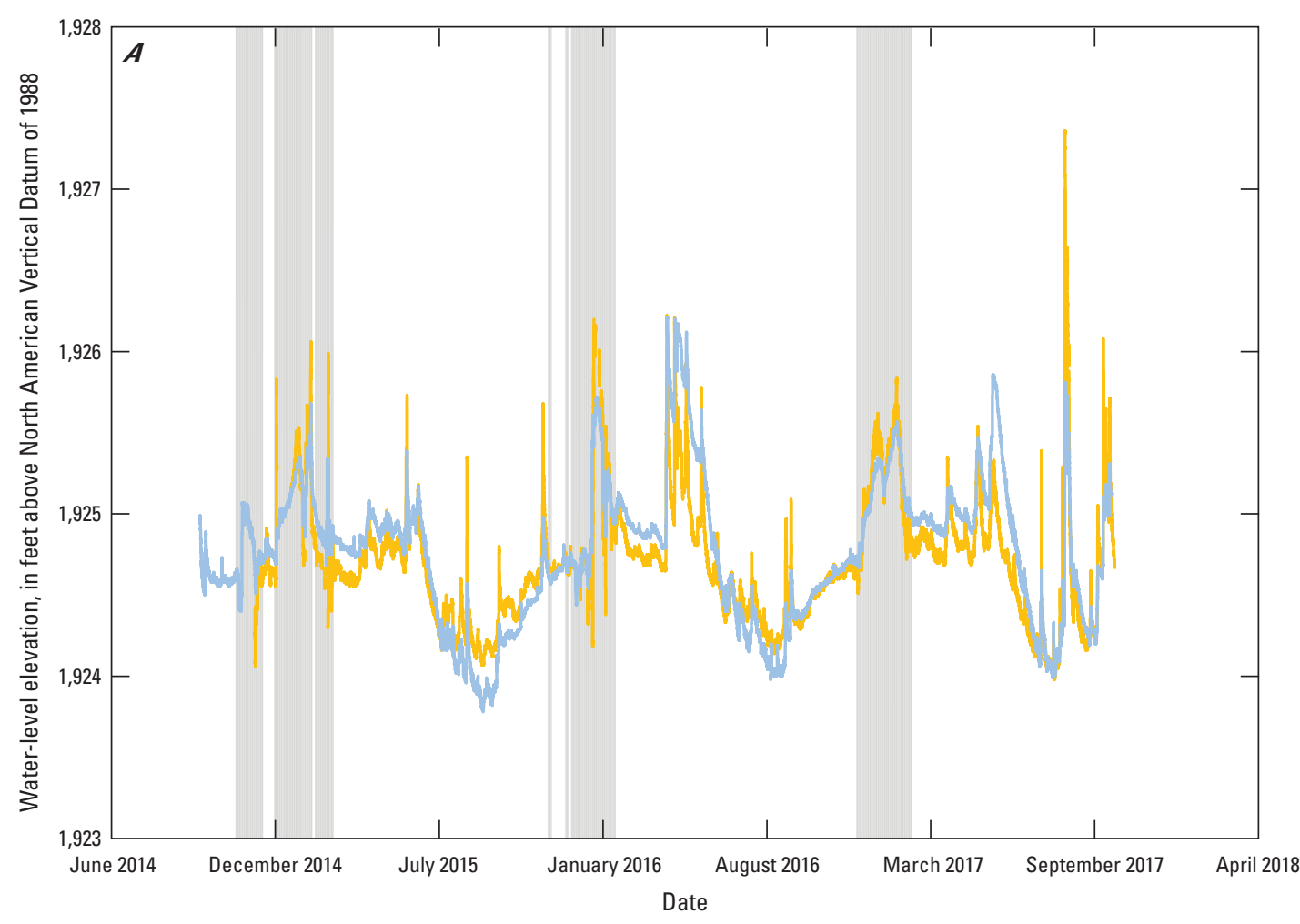

EXPLANATION

Stream stage affected by ice South Loup River stage elevation

- Groundwater elevation

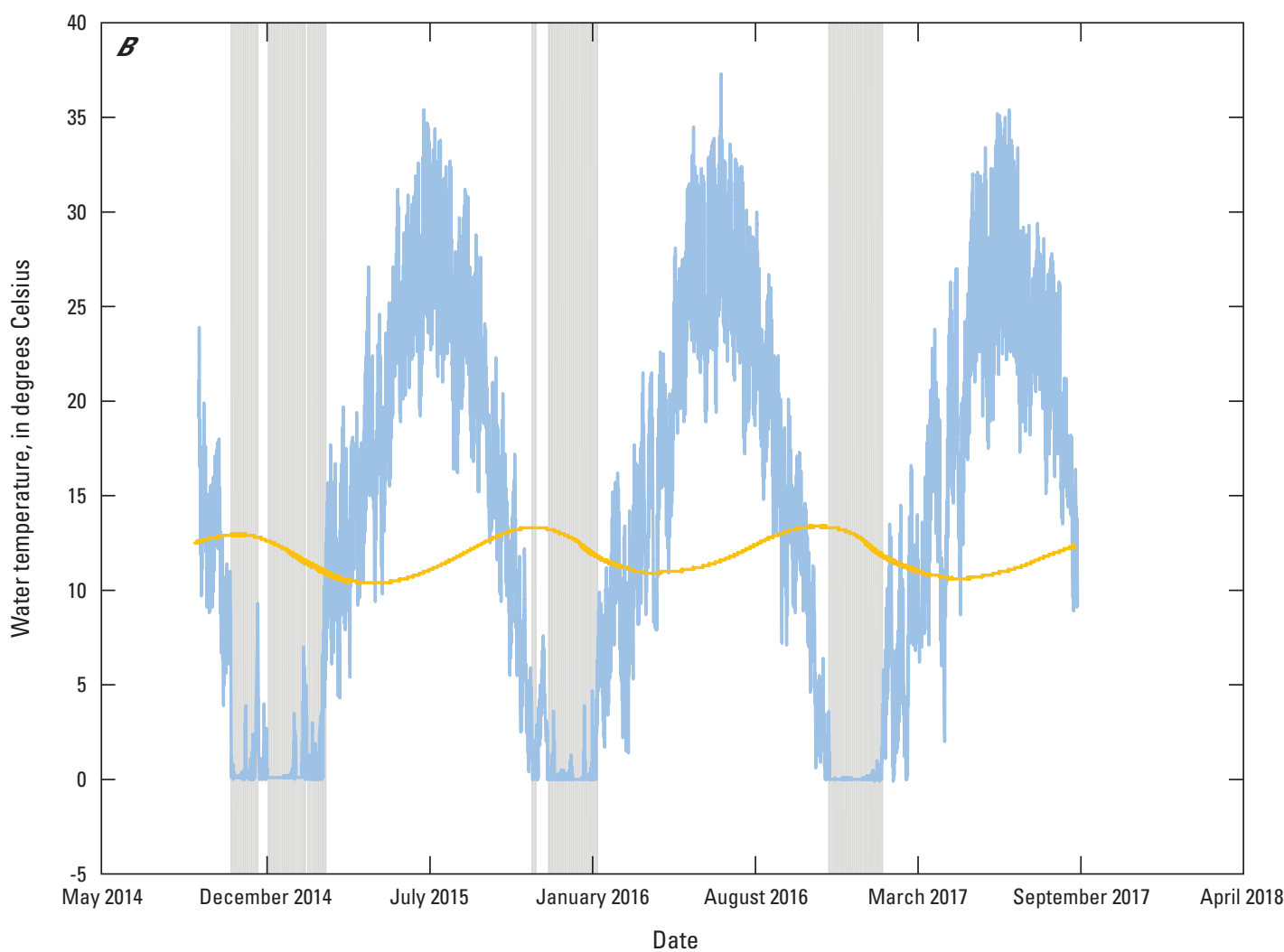

EXPLANATION

Stream stage affected by ice

South Loup River temperature

Groundwater temperature

Figure 17. South Loup River at Saint Michael, Nebraska, streamflow-gaging station (U.S. Geological Survey station 06784000) and nearby observation well. $A$, Stream and groundwater-level elevation. $B$, South Loup River and groundwater temperature. 


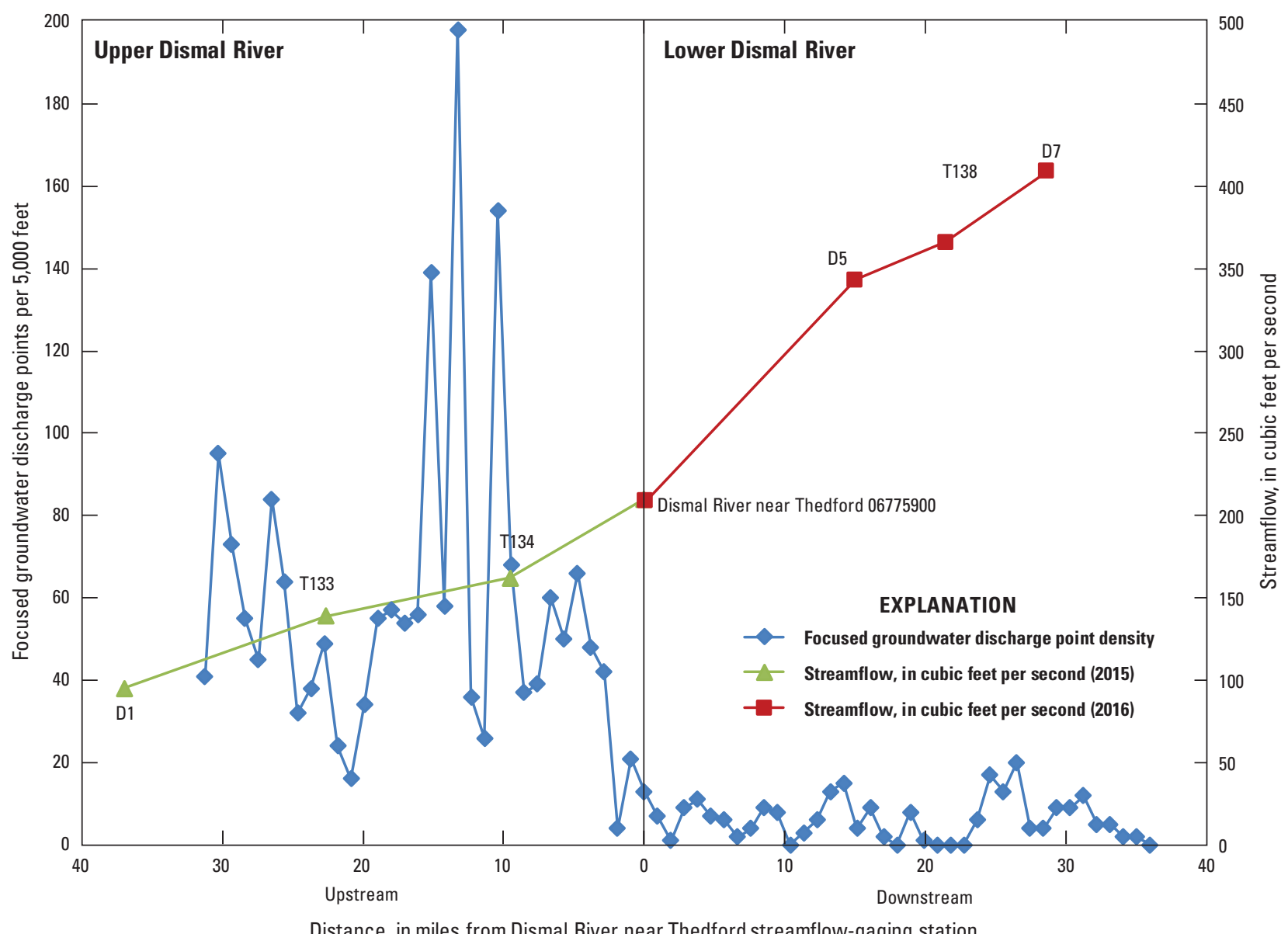

Figure 18. Measured streamflow and the estimated density of focused groundwater discharge points along the Dismal River.

The focused groundwater discharge points, in part, are the result of the formation of vertical flow conduits described in Guhman and Pederson (1992). One vertical flow conduit, locally known as "Blue Pool," is about $35 \mathrm{ft}$ in diameter and $145 \mathrm{ft}$ deep. Based on the stratigraphic interpretation of a nearby test hole (Ahlbrandt and others, 1983; Conservation and Survey Division, University of Nebraska-Lincoln, 2017a), some of these vertical conduits are discharging groundwater from the underlying Ogallala. The "Blue Pool" is on a hillslope approximately $15 \mathrm{ft}$ above and $100 \mathrm{ft}$ back from the active river channel. Guhman and Pederson (1992) pointed out that vertical flow conduits generally have firm, semiconsolidated sides, most likely from mineral precipitation, and are more resistant to erosion compared to surrounding unconsolidated sediments. Because vertical flow conduits are more erosionally resistant, they can persist above the actively incising channel of the Dismal River. Other vertical flow conduits, including one approximately $5 \mathrm{mi}$ downstream from the "Blue Pool" that is approximately $30 \mathrm{ft}$ across (figs. $19 \mathrm{~A}$ and 20), were observed. Active geomorphic processes such as groundwater sapping processes and active headward migration of tributaries, described by Guhman and Pederson (1992), were observed during the spring inventory.
Aerial TIR imagery indicated many focused groundwater discharge points throughout the upper Dismal reach (above the Dismal River streamflow-gaging station; fig. 18). These focused groundwater discharge points likely are the result of strong upward regional groundwater flow gradients near the stream margin and the permeability contrasts of the underlying Pliocene-age sediments. Low permeability sediments, such as siltstone, can restrict the vertical movement of groundwater and concentrate groundwater discharge at focused points. Unfortunately, the "Blue Pool" was not imaged during the December 2015 aerial TIR flight because it is within the upper 5-mi reach where no imagery was acquired; however, other focused groundwater discharge points characterized as vertical flow conduits was mapped. One such vertical conduit is shown in figure $19 \mathrm{~A}$. This vertical flow conduit is similar to the "Blue Pool" in that it has firm sides indicating that the sediments are at least partially consolidated, leaving them resistant to erosion compared to the surrounding sediments. The discharge of this focused groundwater discharge point, which was the largest observed, was estimated to be $2 \mathrm{ft}^{3} / \mathrm{s}$.

The downstream temperature profile of the upper Dismal River indicates little change in the rate of input of groundwater discharge (fig. 21), consistent with streamflow measured 

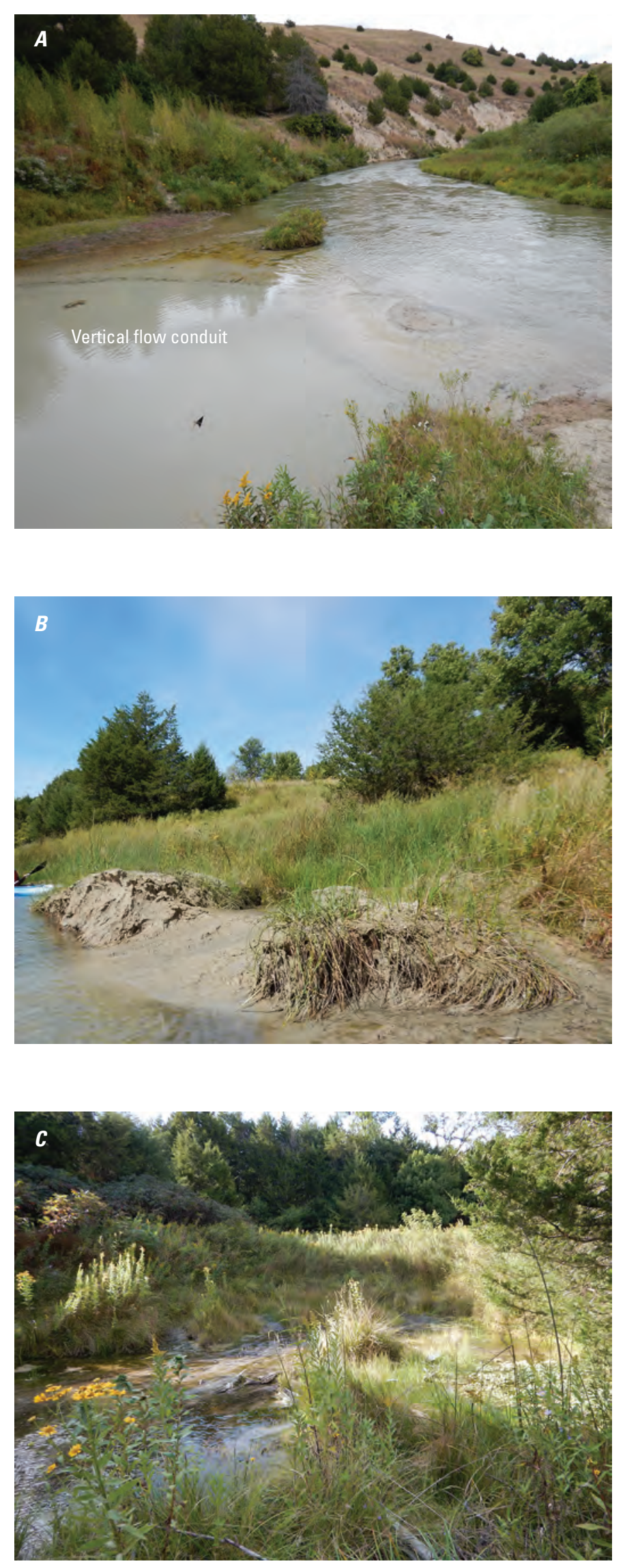

Figure 19. Photographs of example focused groundwater discharge points along the upper Dismal River. $A, A$ large pool overlying a vertical flow conduit approximately 5 miles east of the confluence of the North and South Fork Dismal River. B, Focused groundwater discharge point approximately 1.5 miles east of the confluence of the North and South Fork Dismal River. $C$, Focused groundwater discharge point approximately 9 miles east of the confluence of the North and South Forks Dismal River.

in the stream reconnaissance and streamflow reported in Peterson and Strauch (2007; table 2). One upward spike in the downstream temperature profile was approximately $27 \mathrm{mi}$ above the Dismal River streamflow-gaging station (fig. 21). This upward spike indicates focused groundwater discharge through the streambed near the center of the stream. The downward spikes in the downstream temperature profile were the result of dense tree cover that obscured parts or nearly the entire stream channel. Though only separated by $20 \mathrm{mi}$, the downstream temperature profile of the upper Dismal River (fig. 21) was much warmer $\left(7^{\circ} \mathrm{C}\right)$ than the upper South Loup River and North Fork South Loup River (fig. 9) at the time of the December 2015 flight. The effect of groundwater discharge on the stream temperature of the Dismal River during the late fall is consistent with the stream temperatures measured in the late summer in that stream temperatures were much closer to ambient groundwater temperatures.

\section{Lower Dismal River}

The lower Dismal River begins just downstream from the Dismal River streamflow-gaging station and continues downstream to the east to the confluence with the Middle Loup River at Dunning, Nebr. (fig. 4). A stream reconnaissance of the reach was completed in August 2016 before the collection of aerial TIR imagery. The upper part of this reach, just downstream from the Dismal River streamflow-gaging station, has no public bridge crossings, which made access to this site difficult. The most upstream accessible location was approximately halfway between the Dismal River streamflowgaging station and the confluence with the Middle Loup River (fig. 4). The lower Dismal River transitions from a meandering stream entrenched within a narrow well-defined valley between two barchanoid-ridge dunes to a much wider stream with fewer tight meanders. Along some reaches, the stream is braided with wide shallow channels and exposed sandbars. The streambed texture also transitions from fine sand and sandstone interbedded with siltstone to a fine to medium sand with some areas of coarse sand to fine gravel. Siliceous plant roots, also known rhizoliths or "rootlets," within the streambed material also were noted at all stream reconnaissance locations. Rootlets are a characteristic of the Ogallala (Conservation and Survey Division, University of Nebraska-Lincoln, 2017a; Divine and others, 2015; Hobza and Sibray, 2014) that indicates the stream had incised into the Ogallala at some location upstream. 


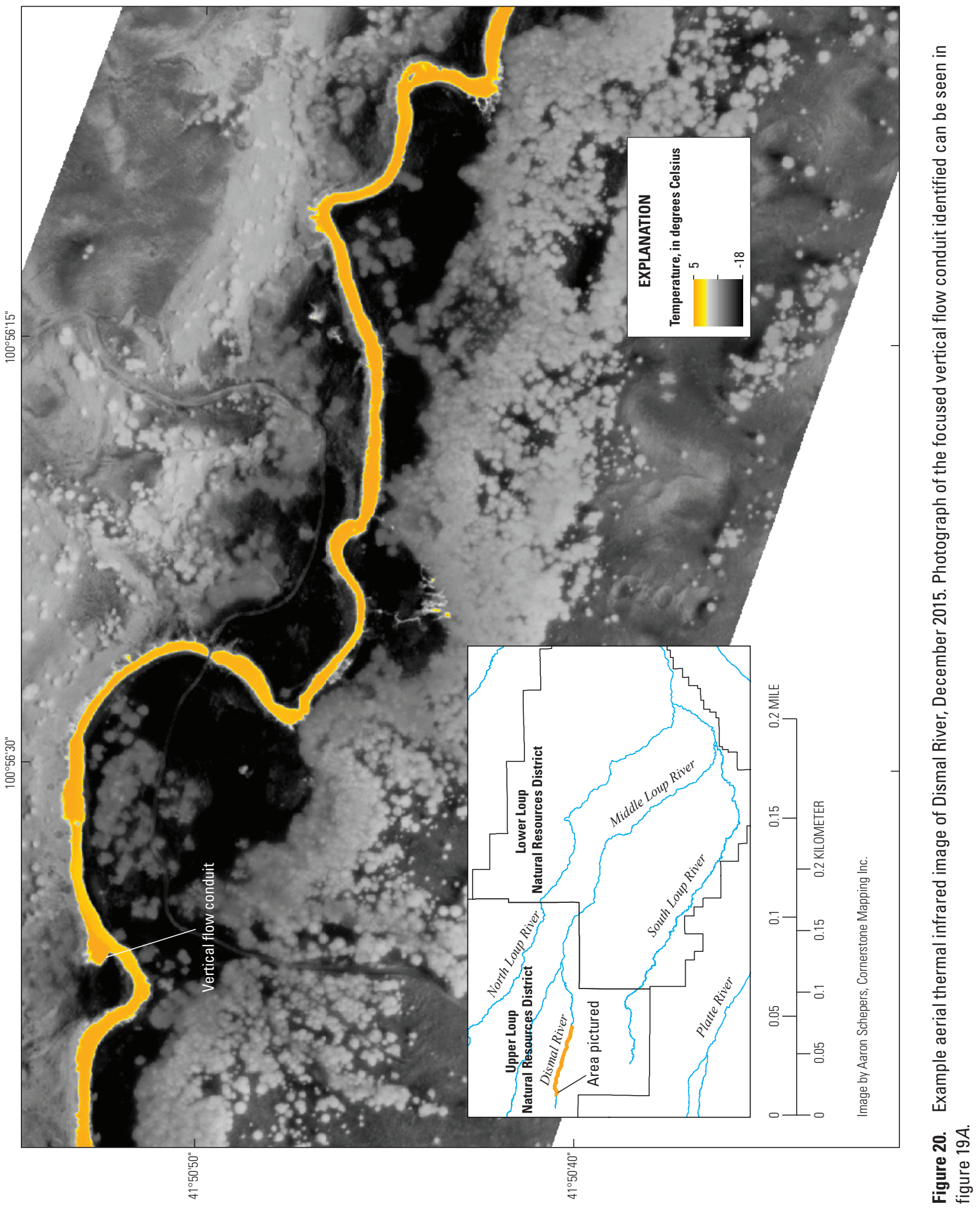




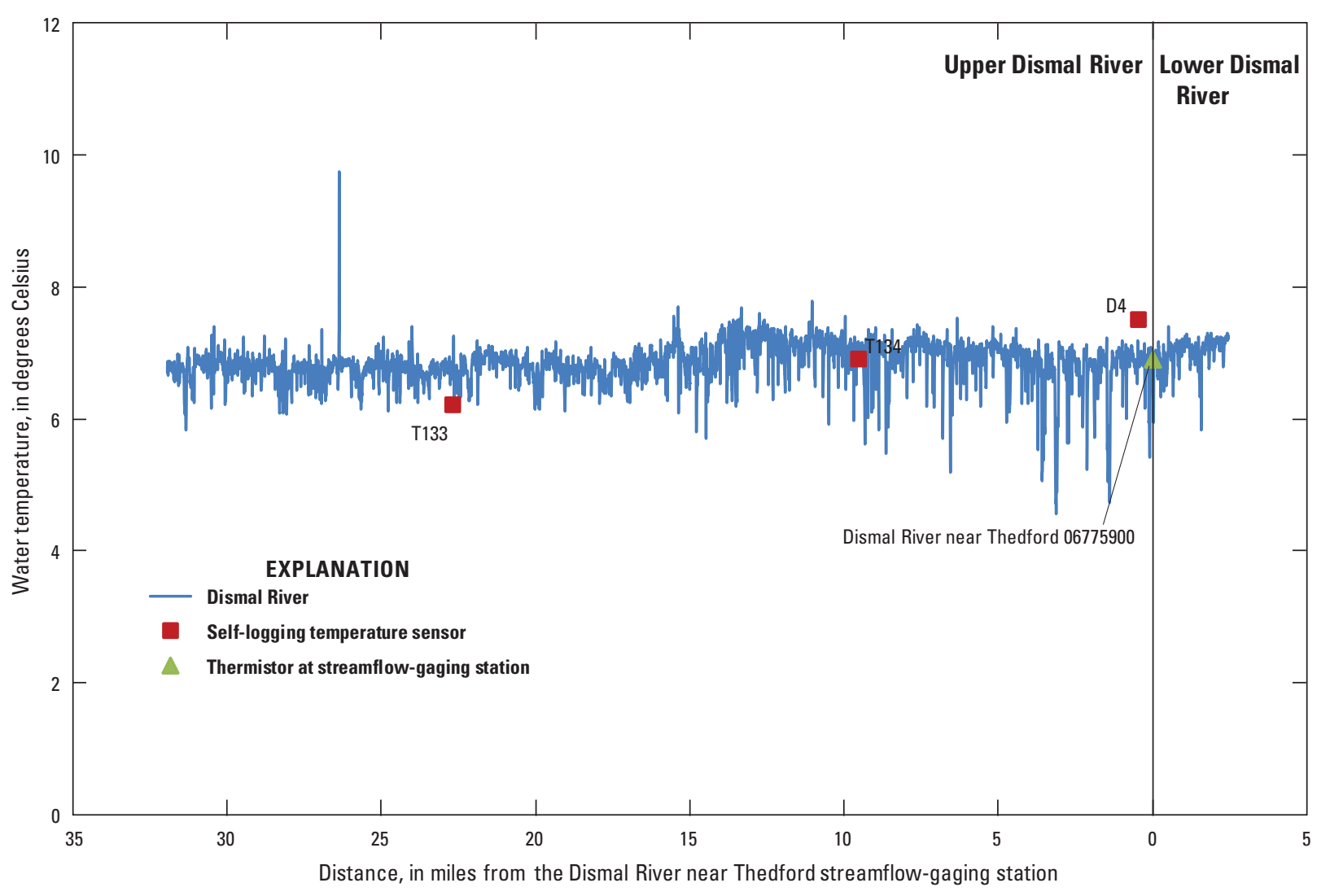

Figure 21. Downstream temperature profile of the upper Dismal River created from aerial thermal infrared imagery collected December 3-4, 2015.

Streamflow measurements collected during the stream reconnaissance generally agree with streamflows measured in 2006 (Peterson and Strauch, 2007) and demonstrate that flows increase throughout the reach (table 2; fig. 18). Although streamflow measurements collected as part of stream reconnaissance for the upper and lower Dismal River reaches were collected 1 year apart, some useful observations still can be made. The median streambed temperature for the lower Dismal River was $3{ }^{\circ} \mathrm{C}$ warmer than the upper Dismal River, indicating that groundwater discharge through the streambed mixes with surface water in the hyporheic zone (table 4). The maximum stream temperature measured along the lower Dismal River was nearly $9{ }^{\circ} \mathrm{C}$ warmer than the maximum temperature measured along the upper Dismal River (table 4). Warmer streambed and stream temperatures measured along the lower Dismal River were expected for a couple of reasons. First, the lower Dismal River is more exposed to atmospheric conditions because channels are much wider and shallower compared to the upper Dismal River. Second, no restrictive layers appear to be within the streambed, which would concentrate the vertical movement of groundwater into the stream, as were with the upper Dismal River. Based on these observations, groundwater discharge through the streambed is more diffuse and mixes with surface water within the hyporheic zone. Potentiomanometer measurements indicate positive vertical head gradients between the groundwater system and the stream. The largest vertical hydraulic gradient measured was much smaller than some vertical hydraulic gradients measured along the upper Dismal River (table 4).

The downstream temperature profile for the lower Dismal River (fig. 22) indicates a slow decrease in stream temperature starting approximately $10 \mathrm{mi}$ downstream from the Dismal River streamflow-gaging station. The decrease in temperature indicates that a smaller proportion of groundwater discharge is entering the stream compared to the total streamflow and that the stream generally is wider and more affected by atmospheric conditions. Upward spikes in the temperature profile are in several locations and are the result of focused groundwater discharge through the streambed. These focused groundwater discharge points are detectable from aerial TIR imagery because of shallow stream depths.

The density of focused groundwater discharge points for the upper and lower Dismal River is shown in figure 18. A sharp decline in the density of focused groundwater discharge points downstream from the Dismal River streamflow-gaging station is shown in figure 18. Most likely, this decrease in the density of focused groundwater discharge points is related to the changes in streambed lithology and underlying geology. Based on mapping by Diffendal (1991), the sediments underlying the lower Dismal River transition from the older Pliocene-Quaternary-age deposits to modern Holocene-age alluvium. This transition is approximately $2 \mathrm{mi}$ downstream 


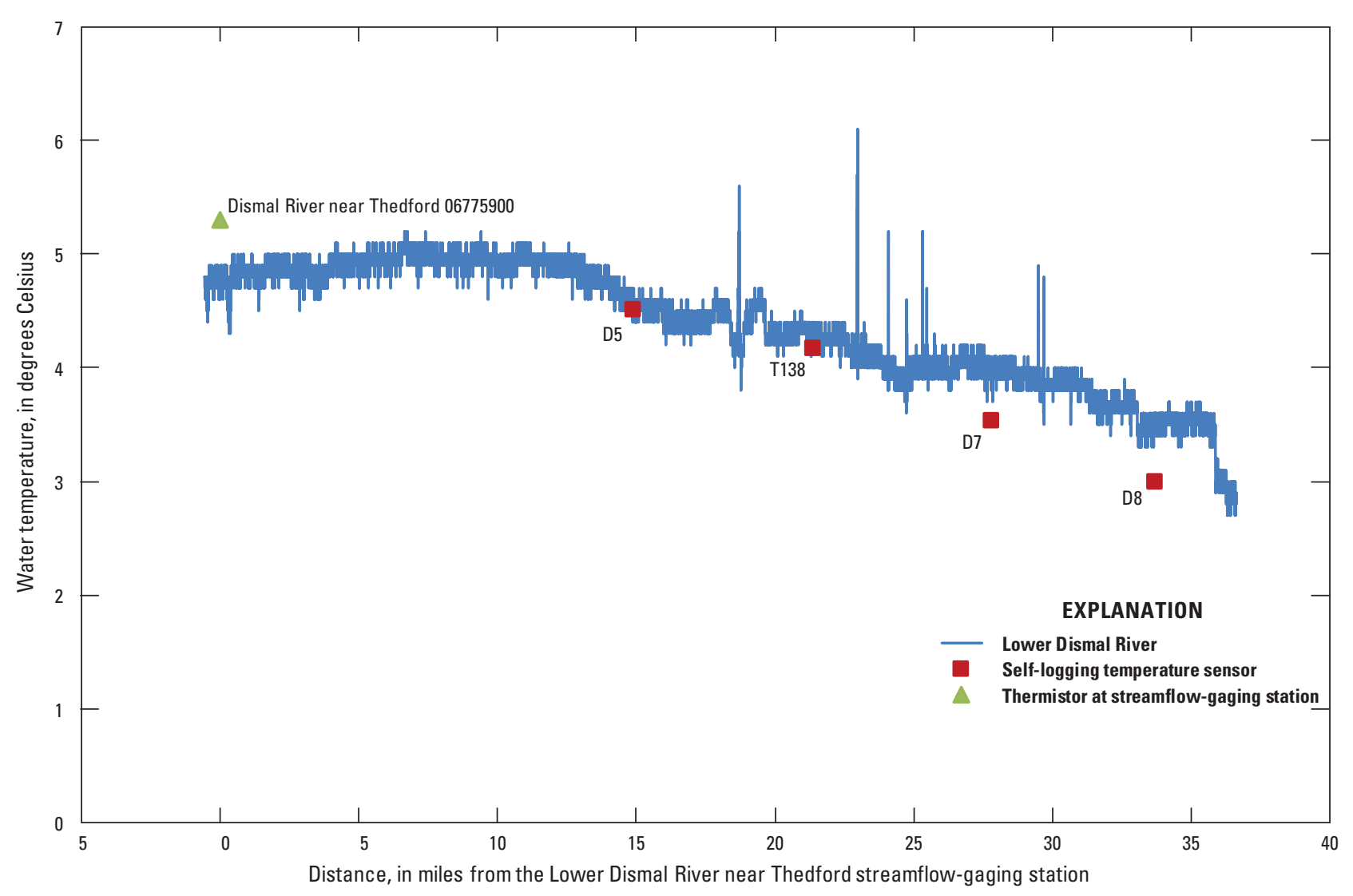

Figure 22. Downstream temperature profile of the lower Dismal River created from aerial thermal infrared imagery collected November 19-20, 2016.

from the Dismal River streamflow-gaging station. Based on the aerial TIR imagery and stream reconnaissance data, the upper Dismal River is dominated by focused groundwater discharge, which increases streamflow across the reach. Groundwater discharge most likely originates from focused points within Pliocene-age deposits along stream margins, but some larger vertical flow conduits originate within the deeper Ogallala (Guhman and Pederson, 1992). Downstream from the Dismal River streamflow-gaging station, diffuse groundwater discharge through the streambed sustains and increases streamflow of the lower Dismal River.

Rootlets in the lower Dismal River indicate that the river has incised into the Ogallala at some point upstream. As part of the phase 3 ELM, Stanton (2013) subdivided the aquifer into two units. Along the Dismal River, those two units include the less permeable Tertiary-age Ogallala and younger, unconsolidated sand and gravel deposits. Elevations were extracted along the river centerline from a digital elevation model (Nebraska Department of Natural Resources and U.S. Geological Survey, 1998) and the elevations from the base of layer 1 (top of the Ogallala) from Stanton (2013) to determine where the Dismal River incised into the Ogallala. Based on these elevations, the Dismal River has incised into the Ogallala immediately downstream from the Dismal River streamflow-gaging station. Ahlbrandt and others (1983) determined the Dismal River most likely has incised into Pliocene-age deposits near the confluence of the North Fork and South Fork of the Dismal Rivers (fig. 4). Farther to the east, closer to the Dismal River streamflow-gaging station, the depth of the contact between the Pliocene deposits and the Ogallala is much less certain. Though not mapped by Diffendal (1991), the river appears to have incised into the Ogallala a short distance downstream from the Dismal River streamflowgaging station.

Water-level and water temperature data collected at the Dismal River streamflow-gaging station were examined to understand the temporal patterns of groundwater discharge to the Dismal River. The groundwater levels measured near the Dismal River streamflow-gaging station (fig. 23A) were higher than stream-level elevations, indicating that the stream was gaining. Changes in groundwater elevation track closely to the river stage elevation, indicating a high degree of connectivity between the stream and shallow groundwater. Even during sharp increases in river stage elevation, which are in response to precipitation events, the difference in elevation between the stream and the groundwater remains consistent, demonstrating that groundwater discharge and gaining conditions are consistent seasonally. The groundwater temperature measured in the nearby observation well displays a cyclical pattern that varies between 12.5 and $13.5^{\circ} \mathrm{C}$, where its annual maximum 

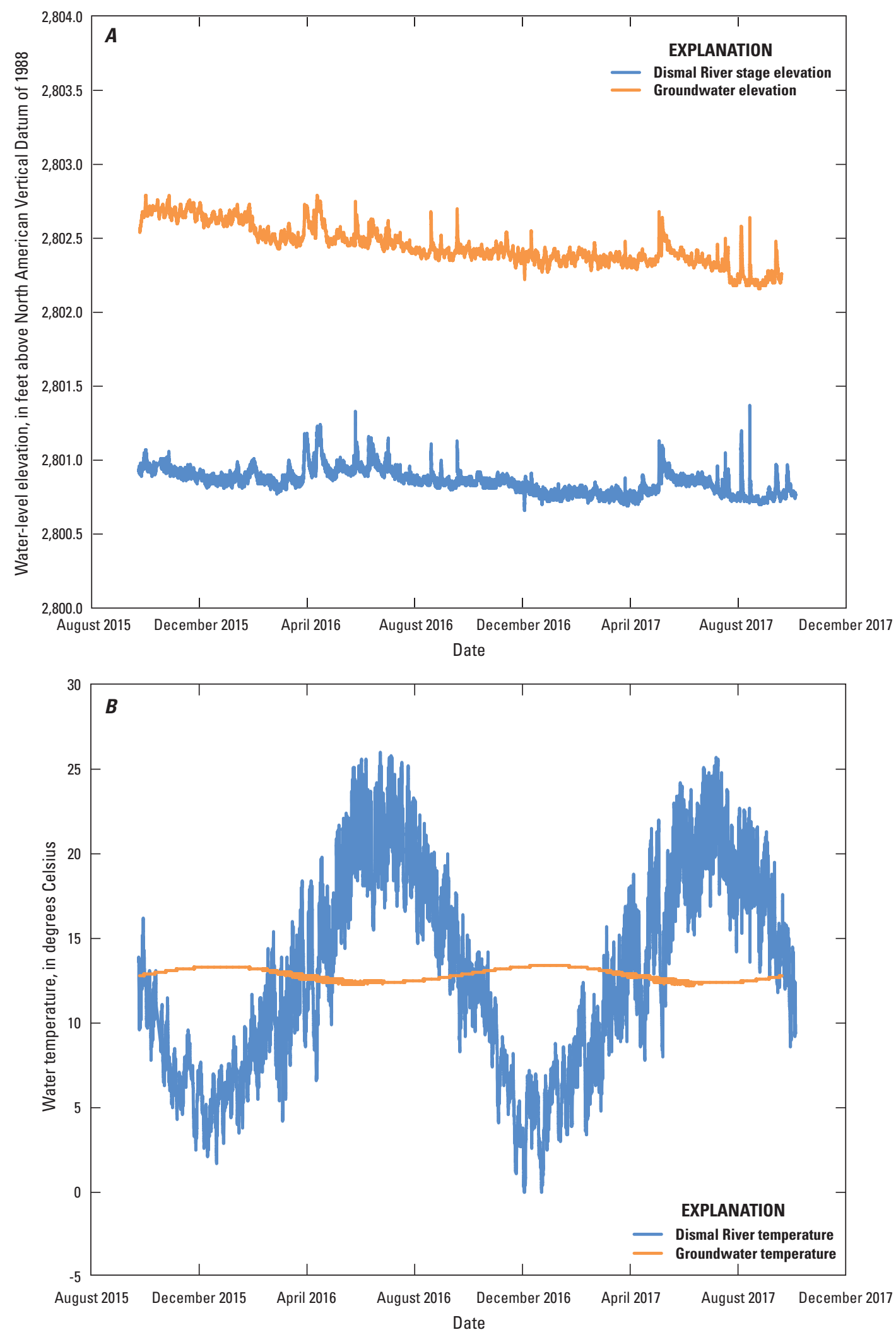

Figure 23. Dismal River near Thedford, Nebraska, streamflow-gaging station (U.S. Geological Survey station 06775900$)$ and nearby observation well. $A$, River stage and groundwater elevation. $B$, Dismal River and groundwater temperature. 
is measured in early winter and its annual minimum is in early summer (fig. 23B). The annual minimum and maximum groundwater temperatures lag behind the annual minimum and maximum stream temperatures. Because the stream is gaining consistently in this location, the changes in groundwater temperature are in response to heat transfer through thermal conduction from surface heating and cooling.

\section{North Loup River}

Streamflow measurements collected during the stream reconnaissance generally agree with streamflows measured in 2006 (Peterson and Strauch, 2007) and demonstrate that flows were increasing throughout the reach up to the TaylorOrd Canal diversion (table 2; fig. 24). During the stream reconnaissance, the Taylor-Ord Canal was diverting water from the North Loup River to satisfy downstream irrigation demands. At that time, the median streamflow for the Taylor streamflow-gaging station was $217 \mathrm{ft}^{3} / \mathrm{s}$, which indicates that more than one-half the flow of the North Loup River $\left(521 \mathrm{ft}^{3} / \mathrm{s}\right.$ at site L428) was diverted. The Nebraska Department of Natural Resources operates a streamflow-gaging station on the Taylor-Ord Canal (station 107000; Nebraska Department of Natural Resources, 2017) approximately 3 mi downstream from the diversion from the North Loup River (fig. 5). Adding the measured discharge of the Taylor-Ord Canal $\left(213 \mathrm{ft}^{3} / \mathrm{s}\right)$ to the discharge measured at the Taylor streamflow-gaging station during the reconnaissance, the North Loup River seemed to lose flow just above the Taylor streamflow-gaging station (fig. 24).

Median and maximum stream and streambed temperature data collected along the North Loup River were warmer than other reaches studied (table 4). The warmer stream and streambed temperatures result from the fact that the North Loup River is affected heavily by atmospheric conditions because the stream is wide and shallow and has little shading from vegetation. The stream reconnaissance locations on the North Loup River were a greater distance from the headwaters compared to the other streams studied (fig. 1). In some locations, the measured streambed temperature approached the regional groundwater temperature, indicating focused groundwater discharge through the streambed and little or no mixing with surface water within the hyporheic zone. Potentiomanometer measurements indicated that the North Loup River is gaining throughout the study reach and indicated substantial variability in vertical hydraulic gradients over short distances (table 4).

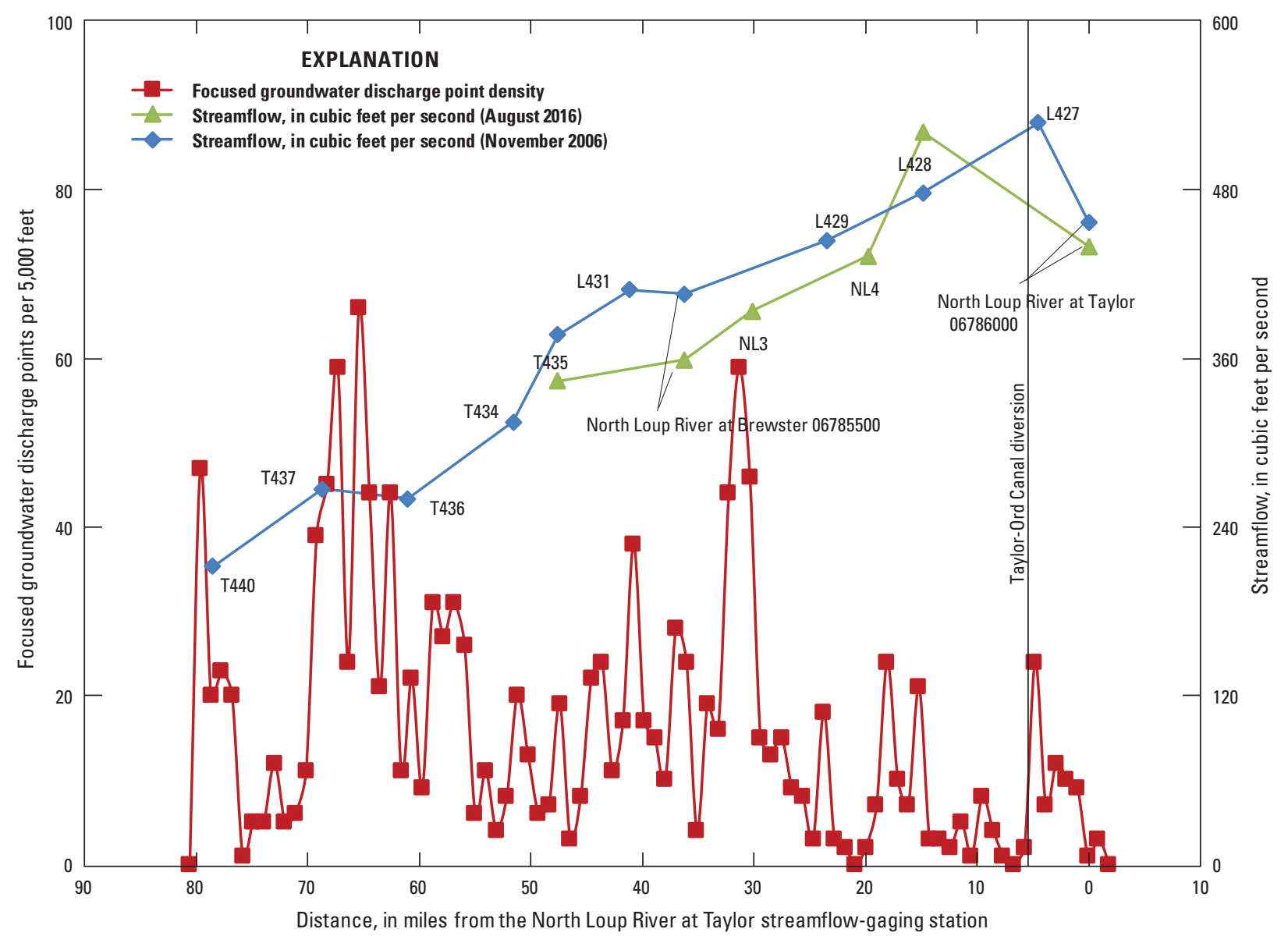

Figure 24. Measured streamflow (November 2006 and August 2016) and the estimated density of focused groundwater discharge points along the North Loup River. 
The downstream temperature profile of the North Loup River indicates fairly constant water temperature across the study reach (fig. 25). Some of the increases in water temperature were associated with increased groundwater discharge. Positive spikes in the downstream temperature profiles that indicate points of focused groundwater discharge through the streambed were seen approximately 25 mi upstream from the North Loup River at Brewster, Nebr., streamflow-gaging station (USGS station 06785500; hereinafter referred to as the "Brewster streamflow-gaging station"). These points are detectable using aerial TIR because they are within shallow parts of the stream. A positive spike approximately $48 \mathrm{mi}$ above the Taylor streamflow-gaging station (about $15 \mathrm{mi}$ upstream from the Brewster streamflow-gaging station) is associated with the confluence of Goose Creek (fig. 5), which is the largest tributary to the North Loup River within the study reach and flows approximately $40 \mathrm{mi}$ before its confluence with the North Loup River. The aerial TIR imagery showed the water temperature of Goose Creek was approximately $1.5^{\circ} \mathrm{C}$ warmer than the North Loup River, which indicated that more of its flow was from recently discharged groundwater.

The density of focused groundwater discharge points is variable across the study reach. Focused groundwater discharge point density varied from nearly 0 to more than 60 points per 5,000 feet. Focused groundwater discharge points were clustered along certain reaches of the North Loup River with higher concentrations mapped upstream from site
NL3 (fig. 24). An area with a large concentration of focused groundwater discharge points is near an active gravel mining operation, which is at site NL3, approximately $5 \mathrm{mi}$ downstream from the Brewster streamflow-gaging station (fig. 24). Sand and gravel outcrops can be seen along the south side of Highway 91, 5 miles east of Brewster, Nebr. well above the elevation of the current stream channel. The age of the gravel currently is not known, but, because a nearly 100 -ft elevation difference is between the sand and gravel outcrop along Highway 91 and the North Loup River (Nebraska Department of Natural Resources and U.S. Geological Survey, 1998), the gravel is most likely Pleistocene or Pliocene age. The focused groundwater discharge points are along the edges of the modern stream valley and along former channel margins (fig. 26). The focused groundwater discharge points are in areas where finer-grained sediments that restrict the vertical movement of groundwater seem to have been eroded away by a combination of headward erosion and groundwater sapping processes.

The North Loup River has incised into Quaternary alluvial and eolian deposits (Souders, 2000); however, rootlets within the streambed material were noted at every stream reconnaissance location, likely because the river incises into the Ogallala at multiple points upstream. River elevations were extracted along the river centerline from a digital elevation model (Nebraska Department of Natural Resources and U.S. Geological Survey, 1998) and the elevations from the base of layer 1 (top of the Ogallala) from Stanton (2013) to determine where the river is incising into the Ogallala. Based

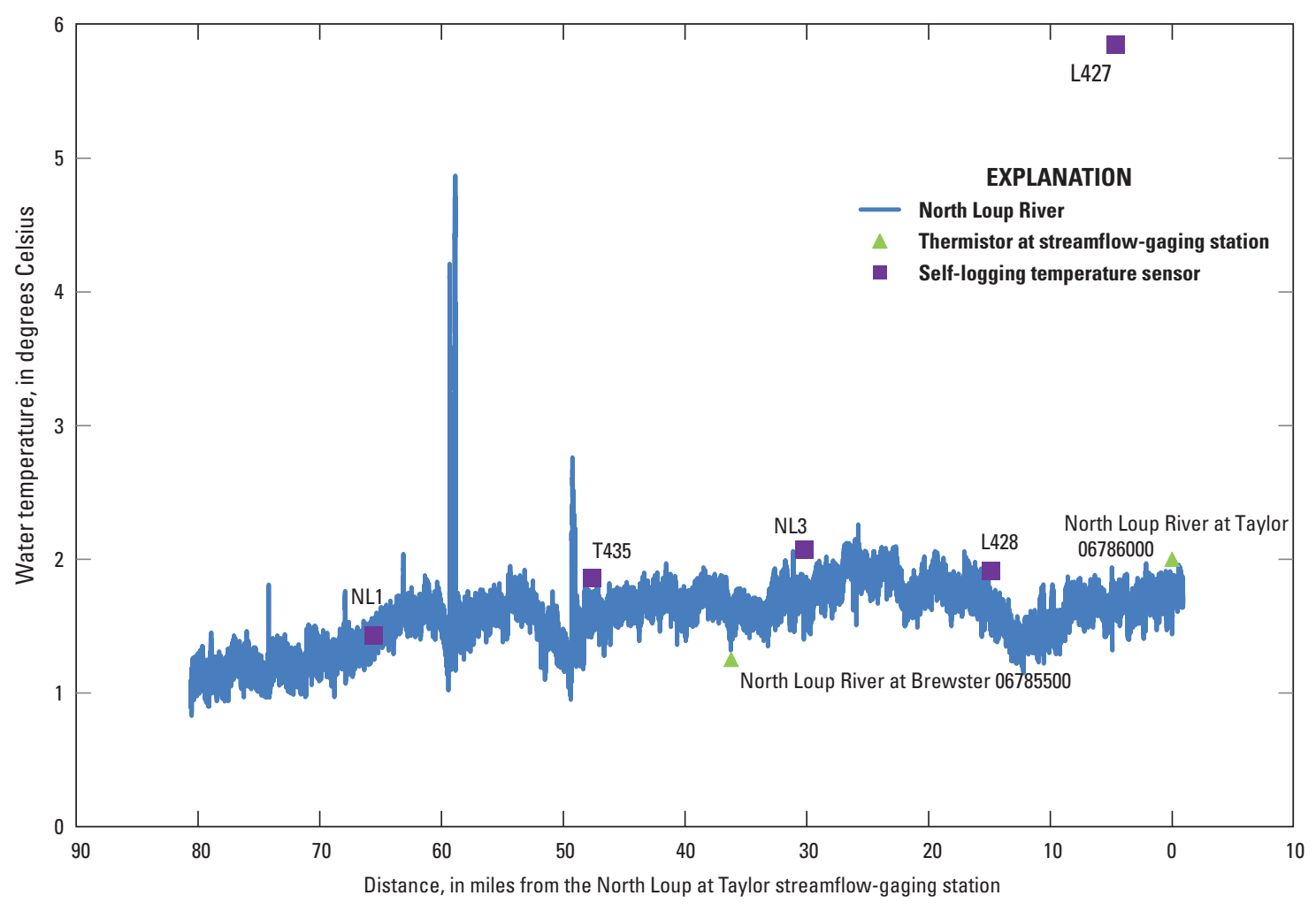

Figure 25. Downstream temperature profile of the North Loup River created from aerial thermal infrared imagery collected November 19-20, 2016. 


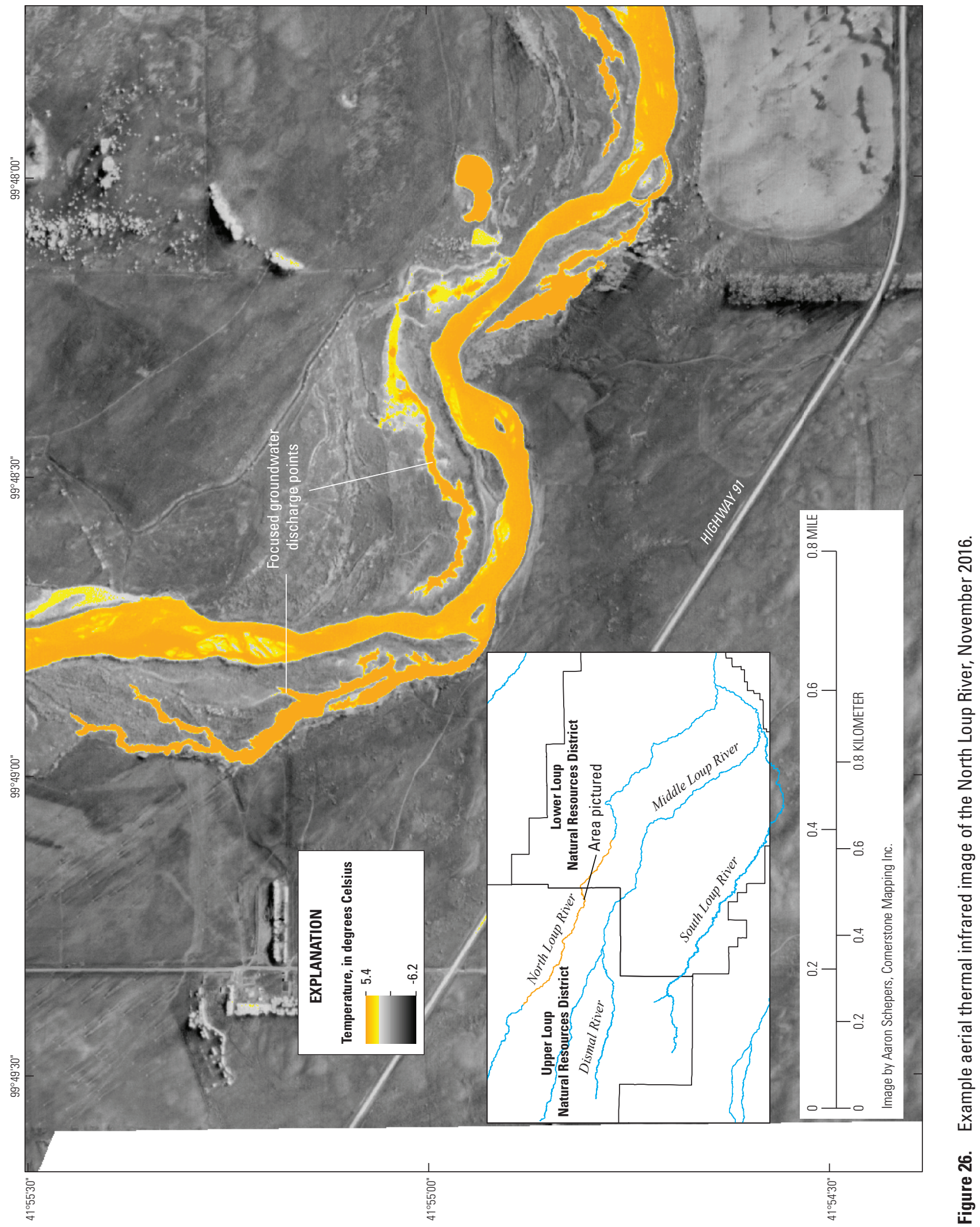


on these elevations, it appears that the North Loup River is incising into the Ogallala in three different locations; approximately 73, 22, and 8 mi upstream from the Taylor streamflowgaging station (fig. 5). At these locations, the density of focused groundwater discharge points approaches 0 (fig. 24), which indicates that the vertical movement of groundwater is somewhat restricted and that the Ogallala is relatively impermeable compared to the overlying sediments. One hypothesis is that the formation of focused groundwater discharge points through groundwater sapping processes may be inhibited because the Ogallala is a semiconsolidated sandstone that is relatively resistant to erosion compared to overlying unconsolidated Quaternary- and Pliocene-age deposits (Gutentag and others, 1984).

Results from the stream reconnaissance and examination of aerial TIR imagery indicate that increases in streamflow along the studied reach of the North Loup River are the result of a combination of focused and diffuse groundwater discharge. Subsurface geologic information indicates that the North Loup River most likely flows over an alternating sequence of Quaternary-age alluvial sediments, Pliocene- or Pleistocene-age sand and gravels, and the Tertiary-age Ogallala. Unfortunately, the precise locations of all these contacts remain unclear at this time. The higher concentration of focused groundwater discharge points possibly was in areas where the North Loup River is flowing over Pliocene-age deposits, creating similar patterns in focused groundwater discharge observed along the upper Dismal River (fig. 18), $25 \mathrm{mi}$ to the southwest.

Water-level and water temperature data collected at two streamflow-gaging stations were examined to understand the temporal patterns of groundwater discharge to the North Loup River. The groundwater levels measured near the Brewster streamflow-gaging station and the Taylor streamflow-gaging station (figs. $27 A$ and 28A) were higher than stream-level elevations, indicating gaining conditions. Changes in groundwater elevation track closely to the stream elevation, indicating a high degree of connectivity between the stream and shallow groundwater. Even during sharp increases in stream elevation, which are in response to precipitation events and ice formation, the difference in elevation between the stream and the groundwater remains consistent, which demonstrates that groundwater discharge and gaining conditions are consistent seasonally. The groundwater-level elevation at the Taylor streamflow-gaging station (fig. 28A) remained above the stream elevation throughout the period of record; however, this difference in elevation decreased through the summer months. The decreased difference most likely is due to increased groundwater pumping and evapotranspiration rates that have lowered groundwater levels locally.

The groundwater temperature measured in the shallow well near the Brewster streamflow-gaging station displays a cyclical pattern that varies between 11.0 and $13.5^{\circ} \mathrm{C}$, where its annual maximum is measured in early winter and its annual minimum is in early summer (fig. 27B). The annual minimum and maximum groundwater temperatures lag behind the annual minimum and maximum stream temperatures. Because the stream is consistently gaining in this location, the changes in groundwater temperature are in response to heat transfer through thermal conduction. The shallow well near the Taylor streamflow-gaging station displayed similar seasonal trends; however, the temperature varied between $10.0{ }^{\circ} \mathrm{C}$ in the fall and $13.9^{\circ} \mathrm{C}$ in the spring (fig. $28 B$ ).

\section{Middle Loup River}

Water-level and water temperature data collected at the Middle Loup River at Dunning streamflow-gaging station were examined to understand the temporal patterns of groundwater discharge to the Middle Loup River, which is immediately above the confluence with the Dismal River (figs. 1 and 4). The groundwater levels measured near the Middle Loup River at Dunning streamflow-gaging station were higher than river stage elevations, indicating that the stream was gaining additional groundwater (fig. 29A). Changes in groundwater elevation track closely to the stream elevation, indicating a high degree of connectivity between the stream and shallow groundwater. Even during sharp increases in stream elevation, which are in response to precipitation events and ice formation, the difference in elevation between the stream and the groundwater remains consistent, which demonstrates that groundwater discharge and gaining conditions are consistent seasonally.

The groundwater temperature measured in the shallow well displays a cyclical pattern that varies between 11.5 and $14.5^{\circ} \mathrm{C}$, where its annual maximum is measured in early winter and its annual minimum is in early summer (fig. 29B). The annual minimum and maximum groundwater temperatures lag behind the annual minimum and maximum stream temperatures. Because the stream is gaining consistently at this location, and the direction of groundwater movement is towards the stream, the changes in groundwater temperature are in response to heat transfer through thermal conduction from surface heating and cooling.

Ice formation within the stream channel appears to have an effect on groundwater levels at the stream margin. In December 2016 and early January 2017, two periods of ice formation on the Middle Loup River caused a sharp increase in stream stage that was not associated with an increase in stream discharge. The increase in stream stage is the result of the backpressure created by ice cover on the stream. Groundwater levels rose in response to this backpressure. Ice conditions temporarily caused the stream elevation to increase and surpass the groundwater-level elevation, indicating losing conditions. A decrease in groundwater temperature during this same time indicated movement of water through the streambed back in the shallow aquifer (fig. 28B). 


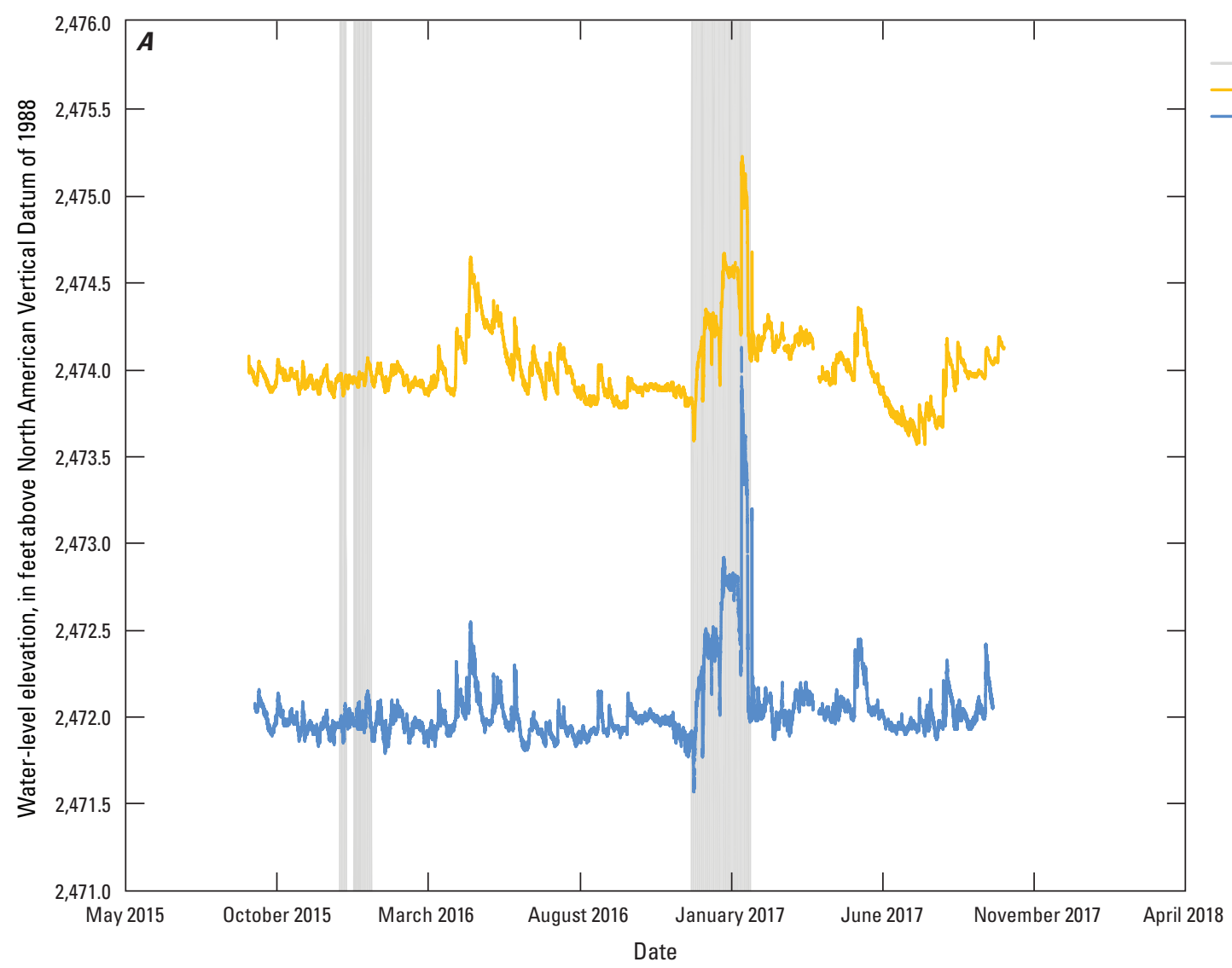

EXPLANATION

Stream stage affected by ice

Groundwater elevation

North Loup River stage elevation

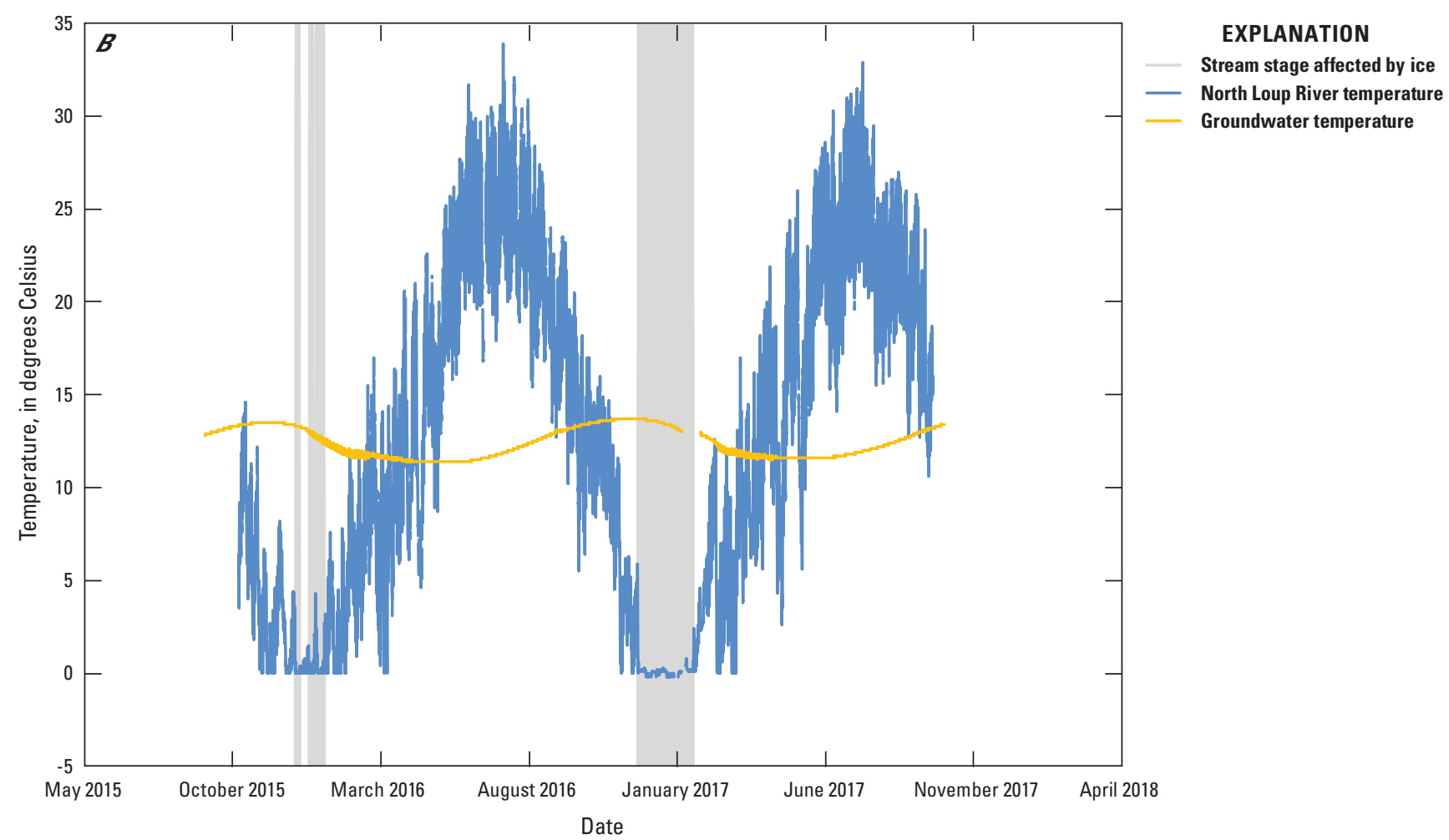

Figure 27. North Loup River at Brewster, Nebraska, streamflow-gaging station (U.S. Geological Survey station 06785500) and nearby observation well from May 2015 to April 2018. A, Stream and groundwater-level elevation. B, North Loup River and groundwater temperature. 


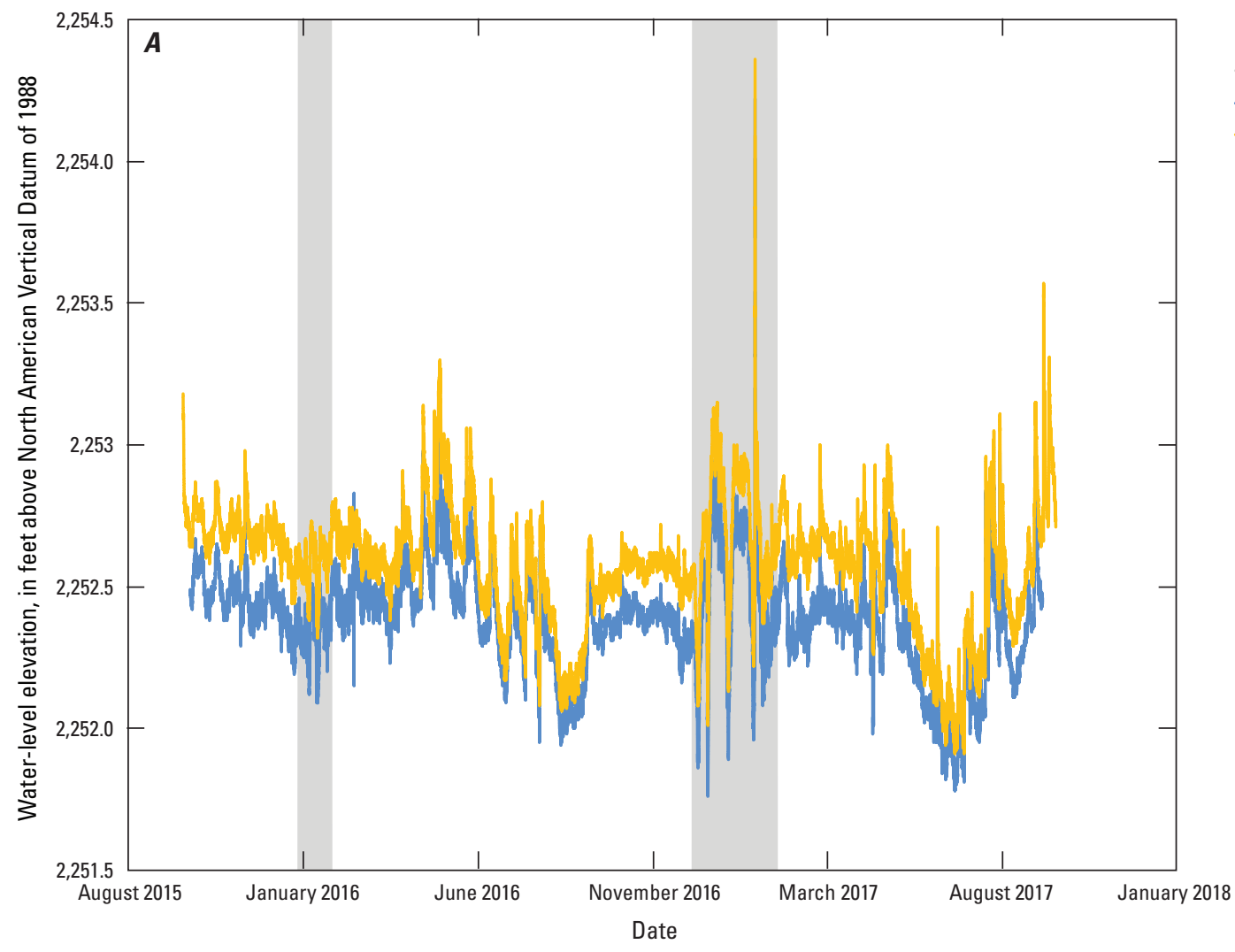

EXPLANATION

Stream stage affected by ice

North Loup River stage elevation

Groundwater elevation

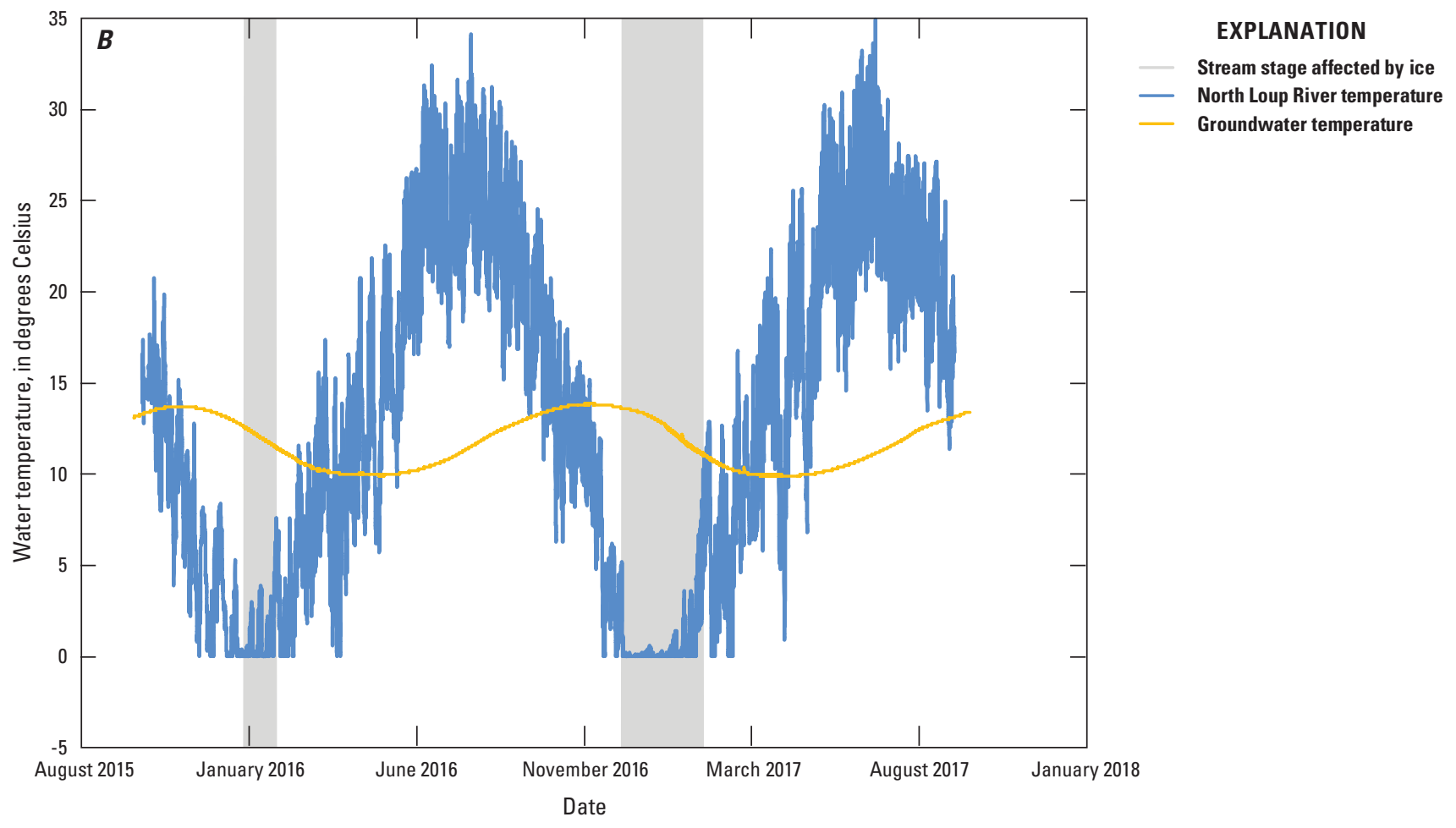

Figure 28. North Loup River at Taylor, Nebraska, streamflow-gaging station (U.S. Geological Survey station 06786000) and nearby observation well from August 2015 to January 2018. A, Stream and groundwater-level elevation. B, North Loup River and groundwater water temperature. 


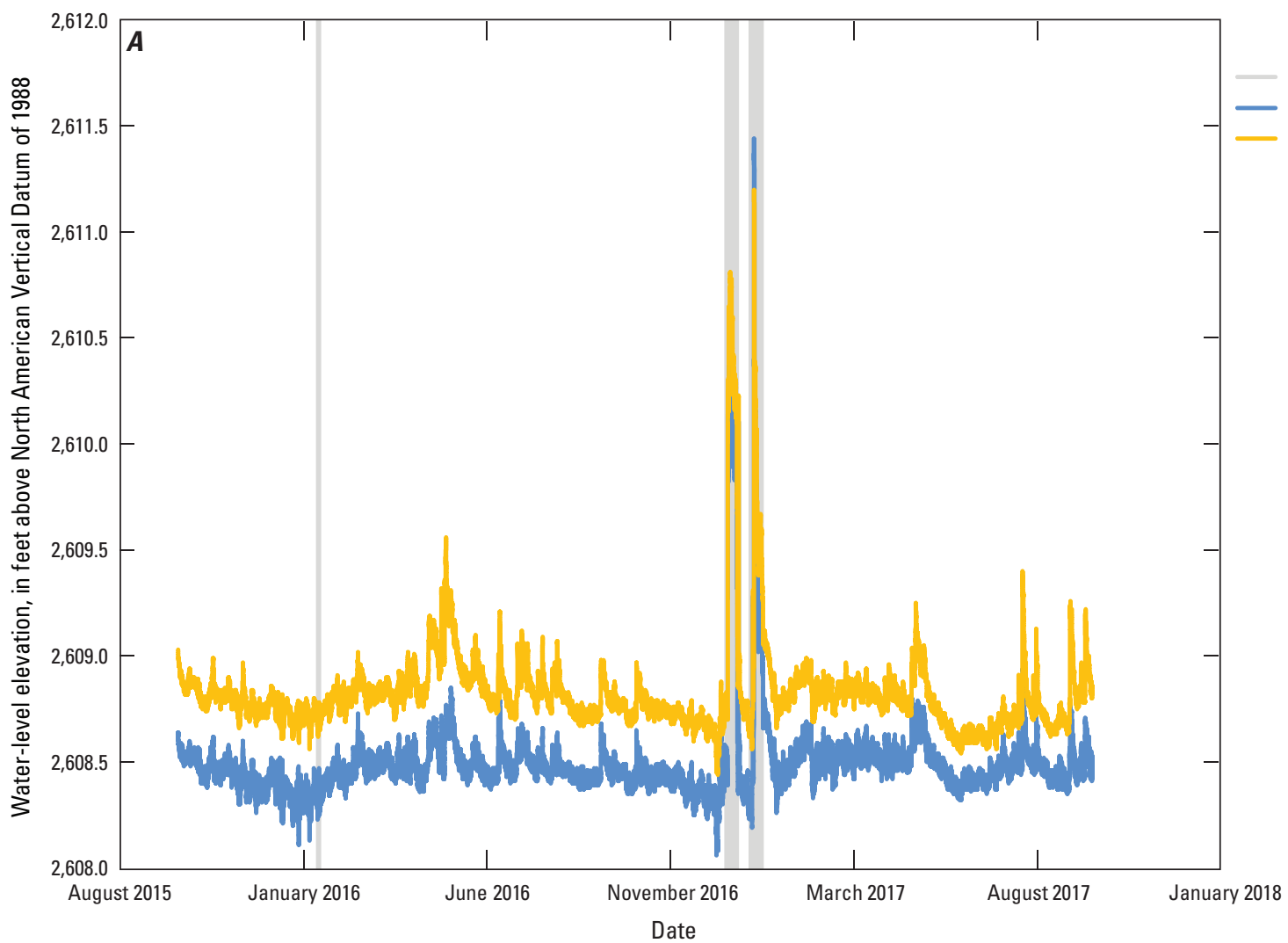

EXPLANATION

Stream stage affected by ice

Middle Loup River stage elevation

Groundwater elevation

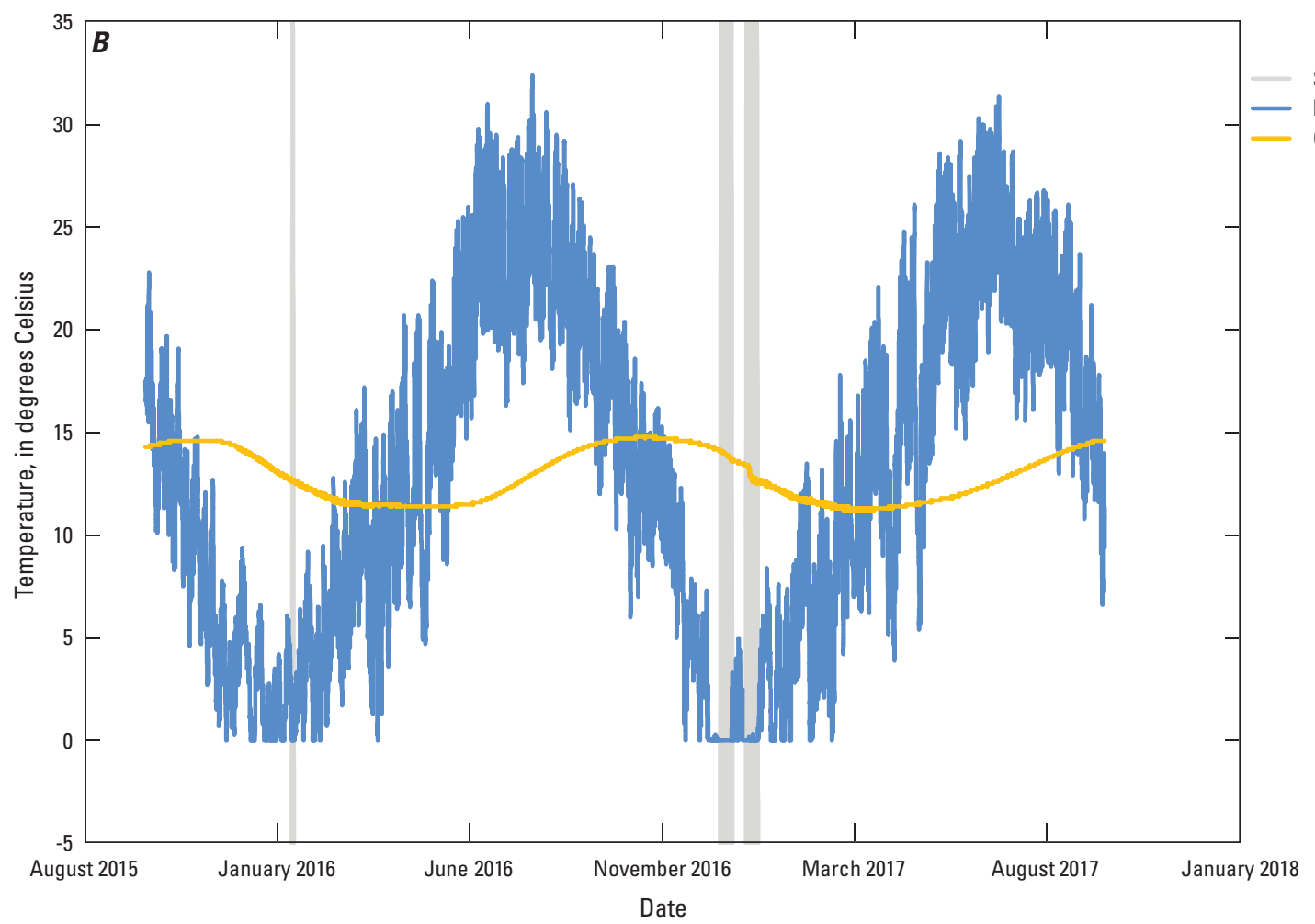

EXPLANATION

Stream stage affected by ice Middle Loup River temperature Groundwater temperature

Figure 29. Middle Loup River at Dunning, Nebraska, streamflow-gaging station (U.S. Geological Survey station 06775500) and nearby observation well from August 2015 to January 2018. A, Stream and groundwater-level elevation. B, Middle Loup River and groundwater water temperature. 


\section{Primary Controls on Groundwater Discharge Characteristics Within the Loup River Basin}

The results from the stream reconnaissance and examination of aerial TIR imagery have demonstrated the effect of the surficial and subsurface geology on the spatial characteristics of groundwater discharge to streams in the Loup River Basin (fig. 1). The patterns and distribution of focused and diffuse groundwater discharge from each stream are the result of the unique geologic framework and lithologic characteristics of Quaternary-, Pleistocene-, and Pliocene-age deposits and of the Tertiary-age Ogallala deposits. Diffuse and focused groundwater discharge from Quaternary-age deposits of silt, sand, and gravel sustain flow for most stream reaches within the Loup River Basin. At the headwaters of the South Loup River, groundwater discharge is dominated by groundwater discharging from Quaternary-age deposits at many small (less than $0.1 \mathrm{ft}^{3} / \mathrm{s}$ ) focused points. The volume of water produced from this dense network of focused groundwater discharge points along the North Fork South Loup River is sufficient to provide approximately 40 percent of the flow measured at the Arnold streamflow-gaging station during the irrigation season.

Pliocene-age sand and gravel deposits also have had a major influence on the spatial patterns of groundwater discharge to the South Loup River. Approximately 5 mi downstream from the Arnold streamflow-gaging station, the river incises into Pliocene-age sand and gravel deposits, providing additional groundwater discharge to the stream. The streamflow of the South Loup River increases by a factor of 5 across a 62-mi reach of the middle South Loup River. The additional streamflow is from a combination of diffuse groundwater discharge through the streambed and large (as much as $1.5 \mathrm{ft}^{3} / \mathrm{s}$ ) focused groundwater discharge points.

On the Dismal River, the lithologic character of Pliocene- and Quaternary-age deposits has a major influence in the distribution and patterns of focused and diffuse groundwater discharge. The upper Dismal River is actively incising into Pliocene deposits that are described locally as interbedded fine sand and weakly consolidated sandstone and siltstone (Conservation and Survey Division, University of Nebraska-Lincoln, 2017a). The river meanders within a narrow, deep valley bound by barchanoid-ridge dunes where high pressure gradients along the stream margin have created conditions favorable for the formation of large focused groundwater discharge points and "boiling" sand springs. Increases in streamflow along the upper Dismal River result from a dense network of focused groundwater discharge points. Just downstream from the Dismal River streamflow-gaging station, the Dismal River incises into the Tertiary-age Ogallala over a short reach before flowing over the top of Quaternary-age alluvial deposits. The lithologic character of the Quaternary-age deposits along the lower Dismal River generally is coarser and more permeable compared to the Pliocene-age deposits along the upper Dismal River. Geomorphically, the Dismal River transitions from a tightly meandering entrenched stream at its upper reach to a wider, shallower, and at times braided stream before its confluence with the Middle Loup River. Focused groundwater discharge points are relatively rare, and diffuse groundwater discharge sustains and increases the streamflow of the lower Dismal River.

Groundwater sapping was evident on some stream reaches and has increased the size and flow of focused groundwater discharge points. Previous researchers have documented streambed incision and groundwater sapping on the upper Dismal River that have created and enlarged focused groundwater discharge points capturing additional groundwater and increasing discharge in the Dismal River (Guhman and Pederson, 1992). This trend can be seen in long-term streamflow records at the Dismal River streamflow-gaging station (fig. 4; U.S. Geological Survey, 2017). Groundwater sapping also appears to have played a role in the formation of larger focused groundwater discharge points, which sustain the flow of the middle South Loup River. The constant flow of groundwater removed finer-grained Quaternary-age sediments and further exposed Pliocene-age gravel deposits. Headward erosion is evident because some of the large focused groundwater discharge points have incised their own draws and terminate in bowl-like depressions away from the stream (figs. 14A and $14 B)$.

The percentage of groundwater-irrigated land within a stream basin is one factor that affects groundwater discharge to streams within the Loup River NRDs. A striking example of this is at the Saint Michael streamflow-gaging station (fig. 17A) where the shallow groundwater levels declined below the level of the stream during the middle to late part of the growing season when consumptive groundwater use was at its peak (July to September). Groundwater levels rebounded in the fall, indicating a return to gaining conditions. The South Loup River Basin above the Saint Michael streamflow-gaging station has the highest percentage of groundwater-irrigated row crops of all the basins examined. Farther upstream, on the middle South Loup River, a groundwater-level recorder (USGS station 411126099422501 ; U.S. Geological Survey, 2017) indicates that water was discharging from Tertiary-age Ogallala into the South Loup River; however, local pumping reduced the amount of groundwater that is discharged to the stream temporarily. After pumping ceases, groundwater levels rebounded to ambient conditions. Continuous groundwater and surface-water levels measured at the Taylor streamflow-gaging station indicated that the stream was receiving groundwater throughout the year; however, when consumptive groundwater use peaks during the middle to late part of the growing season (July to September), the difference in elevation between the groundwater level and the stream elevation decreases, which indicates a reduction in the amount of groundwater discharge received. 


\section{Summary}

Streams in the Loup River Basin are sensitive to groundwater withdrawals because of the close hydrologic connection between groundwater and surface water. Pumping from aquifers that are hydrologically connected to surface-water bodies can have a substantial effect by reducing the groundwater discharge to surface water. Groundwater discharge is the primary component of streamflow in the Loup River Basin and constitutes more than 90 percent of streamflow in the central Sand Hills. Streams in the Loup River Basin receive a combination of focused discharge (groundwater discharge as springs) and diffuse discharge (relatively uniform discharge). These areas of focused groundwater discharge have not been extensively mapped; furthermore, the effect of various climatic and landuse changes on groundwater discharge patterns currently (as of 2018) is unknown. To improve the understanding of geologic controls, such as formation permeability, and various climatic and land-use changes on groundwater discharge, the U.S. Geological Survey (USGS), in cooperation with the Upper Loup Natural Resources District (NRD), the Lower Loup NRD, and the Nebraska Environmental Trust, studied the spatial and temporal characteristics of groundwater discharge within the Loup River Basin.

This report documents the methods of data collection and analysis, which include the collection of approximately 350 river miles of aerial thermal infrared (TIR) imagery during 2015-16 and continuous groundwater-level and temperature data from six streamflow-gaging stations during 2014-16 within the Loup River Basin. These datasets were collected to improve the understanding of geologic controls and spatial patterns of groundwater discharge.

Georeferenced TIR imagery was interpreted within a geographic information system environment using two different analysis methods. The first method involved creating downstream temperature profiles where stream surface temperatures are extracted every 6.6 feet along a digitized stream centerline. The extracted point temperatures were plotted against distance upstream or downstream from a streamflow-gaging station. Because aerial TIR imagery was collected before the onset of ice, warmer stream temperatures would be the result of an increase in the proportion of groundwater discharge, relative to total streamflow. The second analysis method estimated the density of focused groundwater discharge points along individual stream reaches. The density of focused groundwater discharge points was assessed by creating an Esri shapefile and picking individual focused groundwater discharge points through visual inspection of the TIR and reference imagery. Focused groundwater discharge point density was estimated in number of points per 1,000 or 5,000 feet.

The potential land-use and associated groundwater irrigation effects on the temporal variability of groundwater discharge also were evaluated. Additional water-level and temperature data were collected at six streamflow-gaging stations to assess the temporal variability of groundwater discharge. The data collection design consists of a streamflow-gaging station coupled with a nearby observation well completed below the elevation of the streambed and instrumented with a water-level recorder. The comparison of continuous groundwater-level elevation and stream-stage elevation can indicate whether a stream is gaining or losing near the streamflowgaging station. Continuous water temperature was collected in the stream and the shallow observation well to provide further support to groundwater/surface-water interaction trends.

The results from the stream reconnaissance and examination of aerial TIR imagery have demonstrated the influence of the surficial and subsurface geology on the spatial characteristics of groundwater discharge to streams in the Loup River Basin. The patterns and distribution of focused and diffuse groundwater discharge from each stream are the result of the unique geologic framework and lithologic characteristics of Quaternary, Pleistocene, Pliocene, and Tertiary Ogallala deposits. Diffuse and focused groundwater discharge from Quaternary deposits of silt, sand, and gravel sustain flow for most stream reaches within the Loup River Basin.

At the headwaters of the South Loup River, groundwater discharge is dominated by groundwater discharging from Quaternary deposits at many small (less than 0.1 cubic foot per second) focused points. The volume of water produced from this dense network of focused groundwater discharge points along the North Fork South Loup River was sufficient to provide approximately 40 percent of the flow measured at the South Loup River at Arnold, Nebraska, streamflow-gaging station (USGS station 06781600) during the irrigation season. Approximately 5 miles downstream from the South Loup River at Arnold, Nebr., streamflow-gaging station, the river incises into Pliocene-age sand and gravel deposits, providing additional groundwater discharge to the stream. The streamflow of the South Loup River increases by a factor of 5 across a 62-mile reach of the middle South Loup River. The additional streamflow is from a combination of diffuse groundwater discharge through the streambed and large (as much as 1.5 cubic feet per second) focused groundwater discharge points.

On the Dismal River, the lithologic character of Pliocene and Quaternary deposits has a major influence in the distribution and patterns of focused and diffuse groundwater discharge. The upper Dismal River is actively incising into Pliocene deposits that are described locally as interbedded fine sand and weakly consolidated sandstone and siltstone. The river meanders within a narrow, deep valley bound by barchanoid-ridge dunes where high pressure gradients along the stream margin have created conditions favorable for the formation of large focused groundwater discharge points and "boiling" sand springs. Increases in streamflow along upper Dismal River result from a dense network of focused groundwater discharge points. Just downstream from the Dismal River near Thedford, Nebr., streamflow-gaging station (USGS station 06775900), the Dismal River incises into the Ogallala Formation over a short reach before flowing over the top 
of Quaternary-age alluvial deposits. The lithologic character of the Quaternary deposits along the lower Dismal River is generally coarser and more permeable compared to the Pliocene-age deposits along the upper Dismal River. Geomorphically, the Dismal River transitions from a tightly meandering entrenched stream at its upper reach to a wider, shallower, and at times braided stream before its confluence with the Middle Loup River. Focused groundwater discharge points are relatively rare, and diffuse groundwater discharge sustains and increases the streamflow of the lower Dismal River.

Groundwater sapping was evident on some stream reaches and has increased the size and flow of focused groundwater discharge points. Previous researchers have documented streambed incision and groundwater sapping on the upper Dismal River that have created and enlarged focused groundwater discharge points, capturing additional groundwater and increasing discharge in the Dismal River. This trend can be seen in long-term streamflow records at the Dismal River near Thedford, Nebr., streamflow-gaging station. Groundwater sapping also appears to have played a role in the formation of larger focused groundwater discharge points, which sustain flow of the middle South Loup River. The constant flow of groundwater removed finer-grained Quaternary sediments and further exposed Pliocene-age gravel deposits. Headward erosion is evident because some of the large focused groundwater discharge points have incised their own draws and terminate in bowl-like depressions away from the stream.

The percentage of groundwater-irrigated land within a stream basin is one factor that affects groundwater discharge to streams within the Loup River NRDs. The most striking example is at the South Loup River at Saint Michael, Nebr., streamflow-gaging station (USGS station 06784000) where the shallow groundwater levels declined below the level of the stream during the growing season when consumptive groundwater use was at its peak (July to September). Groundwater levels rebounded in the fall, indicating a return to gaining conditions. The South Loup River Basin above the South Loup River at Saint Michael, Nebr., streamflow-gaging station has the highest percentage of groundwater-irrigated row crops of all the basins examined. Farther upstream, on the middle South Loup River, a groundwater-level recorder indicates that water is discharging from the Ogallala Formation into the South Loup River; however, local pumping can reduce the amount of groundwater that is discharged to the stream temporarily. After pumping ceases, groundwater levels rebound to ambient conditions. Continuous groundwater and surfacewater levels measured at the North Loup River at Taylor, Nebr., streamflow-gaging station (USGS station 06786000) indicate that the stream is receiving groundwater throughout the year; however, when consumptive groundwater use peaks during the growing season (July to September), the difference in elevation between the groundwater level and the stream elevation decreases, which indicates a reduction in the amount of groundwater discharge received.

\section{References Cited}

Ahlbrandt, T.S., Swinehart, J.B., and Maroney, D.G., 1983, The dynamic Holocene dune fields of the Great Plains and Rocky Mountain basins, U.S.A., in Brookfield, M.E., and Ahlbrandt, T.S., eds., Eolian sediments and processes: New York, Elsevier Science Publishing Company, p. 379-406. [Also available at https://doi.org/10.1016/S00704571(08)70806-9.]

Anding, D., and Kauth, R., 1970, Estimation of sea surface temperature from space: Remote Sensing of Environment, v. 1, no. 4, p. 217-220. [Also available at https://doi. org/10.1016/S0034-4257(70)80002-5.]

Atwell, B.H., MacDonald, R.B., and Bartolucci, L.A., 1971, Thermal mapping of streams from airborne radiometric scanning: Water Resources Bulletin, v. 7, no. 2, p. 228-243. [Also available at https://doi.org/10.1111/j.1752-1688.1971. tb05904.x.]

Banks, W.S.L., Paylor, R.L., and Hughes, W.B., 1996, Using thermal-infrared imagery to delineate ground-water discharge: Ground Water, v. 34, no. 3, p. 434-443. [Also available at https://doi.org/10.1111/j.1745-6584.1996.tb02024.x.]

Bentall, R., and Shaffer, F.B., 1979, Availability and use of water in Nebraska, 1975: Lincoln, University of Nebraska, Conservation Survey Division, Nebraska Water Survey Paper 48, $121 \mathrm{p}$.

Bleed, A.S., and Flowerday, C.A., eds., 1989, An atlas of the Sand Hills ( $3 \mathrm{~d}$ ed.): Lincoln, University of Nebraska, Conservation and Survey Division, Resource Atlas no. 5b, $260 \mathrm{p}$.

Caissie, D., 2006, The thermal regime of rivers-A review: Freshwater Biology, v. 51, no. 8, p. 1389-1406. [Also available at https://doi.org/10.1111/j.1365-2427.2006.01597.x.]

Chen, X., Chen, X., Rowe, C., Hu, Q., and Anderson, M., 2003, Geological and climatic controls on streamflows in the Nebraska Sand Hills: Journal of the American Water Resources Association, v. 39, no. 1, p. 217-228. [Also available at https://doi.org/10.1111/j.1752-1688.2003.tb01573.x.]

Condon, S.M., 2005, Geologic studies of the Platte River, south-central Nebraska and adjacent areas-Geologic maps, subsurface study, and geologic history: U.S. Geological Survey Professional Paper 1706, 63 p.

Condra, G.E., and Reed, E.C., 1943, The geological section of Nebraska: Lincoln, Nebr., University of Nebraska-Lincoln, Conservation and Survey Division, Nebraska Geological Survey Bulletin, v. 14, p. 82. 
Conservation and Survey Division, University of NebraskaLincoln, 2017a, Test-hole database: University of NebraskaLincoln, Conservation and Survey Division digital data, accessed May 22, 2017, at http://snr.unl.edu/data/geologysoils/NebraskaTestHole/NebraskaTestHoleIntro.aspx.

Conservation and Survey Division, University of NebraskaLincoln, 2017b, Topographic regions, 2017: University of Nebraska-Lincoln, Institute of Agriculture and Natural Resources, digital data, accessed May 15, 2017, at http://snr. unl.edu/data/geographygis/geology.aspx.

Culbertson, C.W., Huntington, T.G., Caldwell, J.M., and O'Donnell, C., 2014, Evaluation of aerial thermal infrared remote sensing to identify groundwater-discharge zones in the Meduxnekeag River, Houlton, Maine: U.S. Geological Survey Open-File Report 2013-1168, 21 p. [Also available at https://doi.org/10.3133/ofr20131168.]

Cunningham, W.L., and Schalk, C.W., comps., 2011, Groundwater technical procedures of the U.S. Geological Survey: U.S. Geological Survey Techniques and Methods, book 1, chap. A1, 151 p. [Also available at https://pubs.usgs.gov/ $\mathrm{tm} / 1 \mathrm{a} 1 /$.

Darton, N.H., 1903, Preliminary report on the geology and water resources of Nebraska west of the one hundred and third meridian: U.S. Geological Survey Professional Paper 17, 69 p., 43 pls. [Also available at https://pubs.usgs. gov/pp/0017/report.pdf.]

Design Analysis Associates, Inc., 2017, Model H-377 Thermistor Temperature Probe owner's manual: Logan, Utah, accessed June 21, 2017, at https://www.waterlog.com/ media/pdfs/H-377-Manual-v1-0.pdf.

Diffendal, R.F., Jr., 1991, Geologic map showing configuration of the bedrock surface, North Platte 1 degree x 2 degrees quadrangle, Nebraska: U.S. Geological Survey Miscellaneous Investigation Series Map I-2277, scale 1:250,000.

Divine, D.P., Joeckel, R.M., and Korus, J.T., 2015, Basic guide for description of cuttings from boreholes in Nebraska: University of Nebraska-Lincoln, Conservation and Survey Division Educational Circular 25, 36 p.

Dugan, J.T., and Zelt, R.B., 2000, Simulation and analysis of soil-water conditions in the Great Plains and adjacent areas, central United States, 1951-80: U.S. Geological Survey Water-Supply Paper 2427, 81 p.

Dugdale, S.J., 2016, A practitioner's guide to thermal infrared remote sensing of rivers and streams - Recent advances, precautions, and considerations: WIREs Water, v. 3, no. 2, p. 251-268. [Also available at https://doi.org/10.1002/ wat2.1135.]
Dugdale, S.J., Bergeron, N.E., and St-Hilaire, A., 2015, Spatial distribution of thermal refuges analyzed in relation to riverscape hydromorphology using airborne thermal infrared imagery: Remote Sensing of Environment, v. 160, p. 43-55. [Also available at https://doi.org/10.1016/j. rse.2014.12.021.]

Eddy-Miller, C.A., Constantz, J., Wheeler, J.D., Caldwell, R.R., and Barlow, J.R.B., 2012, Demonstrating usefulness of real-time monitoring at streambank wells coupled with active streamgages - Pilot studies in Wyoming, Montana, and Mississippi: U.S. Geological Survey Fact Sheet 2012-3054, 6 p. [Also available at https://pubs.usgs.gov/ fs/2012/3054/.]

Esri, 1998, ESRI shapefile technical description-An ESRI white paper: Redlands, Calif., 34 p., accessed July 3, 2018, at https://www.esri.com/library/whitepapers/pdfs/shapefile. pdf.

FLIR, 2011, FLIR SC8300HD User's manual, document number 27525-000, ver. 2: Portland, Oreg., FLIR Systems, Inc., $97 \mathrm{p}$.

FLIR, 2014a, FLIR ResearchIR v4.0 User's guide, document number 29354-000, revision 1: Portland, Oreg., FLIR Systems, Inc., 114 p.

FLIR, 2014b, FLIR Tools/Tools+user's manual: Wilsonville, Oreg., FLIR Systems, Inc., 162 p.

Guhman, A.I., and Pederson, D.T., 1992, Boiling sand springs, Dismal River, Nebraska - Agents for formation of vertical cylindrical structures and geomorphic change: Geology, v. 20, no. 1, p. 8-10. [Also available at https://doi. org/10.1130/0091-7613(1992)020<0008: $\mathrm{BSSDRN}>2.3$ .CO;2.]

Gutentag, E.D., Heimes, F.J., Krothe, N.C., Luckey, R.R., and Weeks, J.B., 1984, Geohydrology of the High Plains aquifer in parts of Colorado, Nebraska, New Mexico, Oklahoma, South Dakota, Texas, and Wyoming: U.S. Geological Survey Professional Paper 1400-B, 63 p.

Harvey, J.W., and Wagner, B.J., 2000, Quantifying hydrologic interactions between streams and their subsurface hyporheic zones, in Jones, J.B., and Mulholland, P.J., eds., Streams and ground waters: San Diego, Academic Press, p. 3-44. [Also available at https://doi.org/10.1016/B978-0123898456/50002-8.]

Hobza, C.M., Asch, T.H., and Bedrosian, P.A., 2011, Hydrostratigraphic interpretation of test-hole and geophysical data, Upper Loup River Basin, Nebraska, 2008-10: U.S. Geological Survey Open-File Report 2011-1289, 60 p. [Also available at https://pubs.usgs.gov/of/2011/1289/.] 
Hobza, C.M., Bedrosian, P.A., and Bloss, B.R., 2012, Hydrostratigraphic interpretation of test-hole and surface geophysical data, Elkhorn and Loup River Basins, Nebraska, 2008 to 2011: U.S. Geological Survey Open-File Report 2012-1227, 95 p. [Also available at https://pubs.usgs.gov/ of/2012/1227/.]

Hobza, C.M. and Densmore, B.K., 2018, Aerial thermal infrared imagery, focused groundwater discharge points, water temperature, streambed temperature, and vertical hydraulic gradient data collected along the South Loup, Dismal, and North Loup Rivers, Nebraska, 2014-16: U.S. Geological Survey data release, https://doi.org/10.5066/F72Z14TP.

Hobza, C.M., and Sibray, S.S., 2014, Hydrostratigraphic interpretation of test-hole and borehole geophysical data, Kimball, Cheyenne, and Deuel Counties, Nebraska, 2011-12: U.S. Geological Survey Open-File Report 2014-1103, 45 p. [Also available at https://doi.org/10.3133/ofr20141103.]

Hutson, S.S., Barber, N.L., Kenny, J.F., Linsey, K.S., Lumia, D.S., and Maupin, M.A., 2004, Estimated use of water in the United States in 2000: U.S. Geological Survey Circular $1268,46 \mathrm{p}$.

Kennedy, C.D., Genereux, D.P., Corbett, D.R., and Mitasova, H., 2007, Design of a light-oil piezomanometer for measurement of hydraulic head differences and collection of groundwater samples: Water Resources Research, v. 43, W09501, 9 p. [Also available at https://doi. org/10.1029/2007WR005904.]

Kenney, T.A., 2010, Levels at gaging stations: U.S. Geological Survey Techniques and Methods, book 3, chap. A19, 60 p. [Also available at https://pubs.usgs.gov/tm/tm3A19/.]

Liu, C., Liu, J., Hu, Y., Wang, H., and Zheng, C., 2016, Airborne thermal remote sensing for estimation of groundwater discharge to a river: Ground Water, v. 54, no. 3, p. 363-373. [Also available at https://doi.org/10.1111/gwat.12362.]

Loheide, S.P., and Gorelick, S.M., 2006, Quantifying streamaquifer interactions through analysis of remotely sensed thermographic profiles and in situ temperature histories: Environmental Science \& Technology, v. 40, no. 10, p. 3336-3341. [Also available at https://doi.org/10.1021/ es0522074.]

Loope, D.B., and Swinehart, J.B., 2000, Thinking like a dune field-Geologic history in the Nebraska Sand Hills: Great Plains Research, v. 10, p. 5-35.

Lower Loup Natural Resources District, 2016, Lower Loup Natural Resources District Voluntary Integrated Management Plan: Lower Loup Natural Resources District, Olsson Project No. 015-2429, 33 p., accessed June 6, 2017, at https://dnr.nebraska.gov/sites/dnr.nebraska. gov/files/doc/water-planning/nrd/lower-loup/20160427_ LLIMP_2016FINAL.pdf.
Magellan, 2007, MobileMapper CX getting started guide: San Dimas, Calif., Magellan, 86 p.

Maher, H.D., Jr., Engelmann, G.F., and Shuster, R.D., 2003, Roadside geology of Nebraska: Missoula, Mont., Mountain Press Publishing Company, $264 \mathrm{p}$.

McGuire, V.L., Lund, K.D., and Densmore, B.K., 2012, Saturated thickness and water in storage in the High Plains aquifer, 2009, and water-level changes and changes in water in storage in the High Plains aquifer, 1980 to 1995,1995 to 2000, 2000 to 2005, and 2005 to 2009: U.S. Geological Survey Scientific Investigations Report 2012-5177, 28 p. [Also available at https://pubs.usgs.gov/sir/2012/5177/.]

Mikhail, E.M., Bethel, J., and McGlone, C., 2001, Introduction to modern photogrammertry: Hoboken, N.J., John Wiley and Sons Publishers, 496 p.

National Climatic Data Center, 2017, Climate data online, weather observation station daily summaries: Asheville, N.C., National Climatic Data Center, digital data, accessed May 18, 2017, at https://www.ncdc.noaa.gov/cdo-web/datatools/normals.

Nebraska Association of Resource Districts, 2013a, Know your NRD: Lower Loup information sheet, Lincoln, Nebr., 2 p., accessed June 6, 2017, at https://www.nrdnet.org/sites/ default/files/downloads/lower_loup.pdf.

Nebraska Association of Resource Districts, 2013b, Know your NRD: Upper Loup information sheet, Lincoln, Nebr., 2 p., accessed June 6, 2017, at https://www.nrdnet.org/sites/ default/files/downloads/upper_loup.pdf.

Nebraska Department of Natural Resources, 2017, 107000 Taylor-Ord Canal from North Loup River: Lincoln, Nebr., accessed July 15, 2017, at https://nednr.nebraska.gov/RealTime/Stations/Details/107000.

Nebraska Department of Natural Resources and U.S. Geological Survey, 1998, 7.5-minute digital elevation modelsDEM-10 meter - Index for the State of Nebraska: Menlo Park, Calif., U.S. Geological Survey, digital data, accessed October 10, 2017, at https://dnr.nebraska.gov/sites/dnr. nebraska.gov/files/doc/data/elevation/DEM.html.

Omega, 2017, Waterproof digital thermometer with probe: Omega, 1 p., accessed June 19, 2017, at https://www. omega.com/temperature/pdf/DP8891.pdf.

Onset, 2017, Tidbit v2 temp manual: Onset Computer Corporation, 2 p., accessed June 19, 2017, at http://www.onsetcomp.com/files/manual_pdfs/10385-I\%20UTBI-001\%20 Manual.pdf. 
Ostdiek, A., 2009, The integrated management planning process: Lincoln, Nebr., Water Matters, no. 1, 4 p., accessed January 8, 2018, at https://dnr.nebraska.gov/sites/dnr. nebraska.gov/files/doc/water-planning/water-matters/WaterMatters_No1.pdf.

Peterson, S.M., Flynn, A.T., and Traylor, J.P., 2016, Groundwater-flow model of the Northern High Plains aquifer in Colorado, Kansas, Nebraska, South Dakota, and Wyoming: U.S. Geological Survey Scientific Investigations Report 2016-5153, 88 p., accessed July 2017 at https://doi. org/10.3133/sir20165153.

Peterson, S.M., Stanton, J.S., Saunders, A.T., and Bradley, J.R., 2008, Simulation of ground-water flow and effects of ground-water irrigation on base flow in the Elkhorn and Loup River Basins, Nebraska: U.S. Geological Survey Scientific Investigations Report 2008-5143, 65 p. [Also available at https://pubs.usgs.gov/sir/2008/5143/.]

Peterson, S.M., and Strauch, K.R., 2007, Streamflow measurements in north-central Nebraska, November 2006: U.S. Geological Survey Data Series 332, 29 p. [Also available at https://pubs.usgs.gov/ds/332/.]

Rosenberry, D.O., and LaBaugh, J.W., 2008, Field techniques for estimating water fluxes between surface water and ground water: U.S. Geological Survey Techniques and Methods, book 4, chap. D2, 128 p. [Also available at https:// pubs.usgs.gov/tm/04d02/.]

Rundquist, D., Murray, G., and Queen, L., 1985, Airborne thermal mapping of a flow-through lake in the Nebraska Sandhills: Water Resources Bulletin, v. 21, no. 6, p. 989-994. [Also available at https://doi. org/10.1111/j.1752-1688.1985.tb00193.x.]

Rydlund, P.H., Jr., and Densmore, B.K., 2012, Methods of practice and guidelines for using survey-grade global navigation satellite systems (GNSS) to establish vertical datum in the United States Geological Survey: U.S. Geological Survey Techniques and Methods, book 11, chap. D1, 102 p. with app. [Also available at https://pubs.usgs.gov/tm/11d1/ tm11-D1.pdf.]

SimActive Inc., 2016, Correlator3D User manual, ver. 6.5: Montreal, Quebec, SimActive Inc., 88 p.

Sokkia Topcon Co., Ltd., 2000, SDL30 SDL50 digital level operator's manual: Kanagawa, Japan, 84 p., accessed June 19, 2017, at https://eu.sokkia.com/sites/default/files/sc_files/ downloads/sdl30-50_operators_manual___13th_ed.pdf.

Souders, V.L., 2000, Geologic maps and cross sections showing configurations of bedrock surfaces, Broken Bow 1 x 2 degree quadrangle, east-central Nebraska: U.S. Geological Survey Geologic Investigations Series I-2725, scale $1: 250,000$.
Stanley, K.O., and Wayne, W.J., 1972, Epeirogenic and climatic controls of Early Pleistocene fluvial sediment dispersal in Nebraska: Geological Society of America Bulletin, v. 83, no. 12, p. 3675-3690. [Also available at https:// doi.org/10.1130/0016-7606(1972)83[3675:EACCOE]2.0 .CO;2.]

Stanton, J.S., 2013, Base of the upper layer of the phase-three Elkhorn-Loup groundwater-flow model, north-central Nebraska: U.S. Geological Survey Scientific Investigations Map 3259, 1 sheet. [Also available at https://doi. org $/ 10.3133 / \operatorname{sim} 3259$.]

Stanton, J.S., Peterson, S.M., and Fienen, M.N., 2010, Simulation of groundwater flow and effects of groundwater irrigation on stream base flow in the Elkhorn and Loup River Basins, Nebraska, 1895-2055-Phase Two: U.S. Geological Survey Scientific Investigations Report 2010-5149, 78 p. with app. [Also available at https://pubs.usgs.gov/ $\operatorname{sir} / 2010 / 5149 /$.

Stanton, J.S., Qi, S.L., Ryter, D.W., Falk, S.E., Houston, N.A., Peterson, S.M., Westenbroek, S.M., and Christenson, S.C., 2011, Selected approaches to estimate water-budget components of the High Plains, 1940 through 1949 and 2000 through 2009: U.S. Geological Survey Scientific Investigations Report 2011-5183, 79 p. [Also available at https:// pubs.usgs.gov/sir/2011/5183/pdf/sir2011-5183.pdf.]

Strauch, K.R., and Linard, J.I., 2009, Streamflow simulations and percolation estimates using the Soil and Water Assessment Tool for selected basins in North-Central Nebraska, 1940-2005: U.S. Geological Survey Scientific Investigations Report 2009-5075, 20 p. [Also available at https:// pubs.usgs.gov/sir/2009/5075/.]

Swinehart, J.B., and Diffendal, R.F., Jr., 1989, Geology of the pre-dune strata, in Bleed, A.S., and Flowerday, C.A., eds., An atlas of the Sand Hills: Lincoln, Nebr., University of Nebraska, Conservation and Survey Division, Resource Atlas, no. 5, p. 29-42.

Swinehart, J.B., Souders, V.L., DeGraw, H.M., and Diffendal, R.F., Jr., 1985, Cenozoic paleogeography of western Nebraska, in Flores, R.M., and Kaplan, S.S., eds., Cenozoic paleogeography of the west-central United States: Denver, Colo., S.E.P.M. Rocky Mountain Section, Rocky Mountain Paleogeography Symposium 3, p. 209-229.

Szilagyi, J., Harvey, F.E., and Ayers, J.F., 2003, Regional estimation of base recharge to ground water using water balance and a base flow index: Ground Water, v. 41, no. 4, p. 504-513. [Also available at https://doi. org/10.1111/j.1745-6584.2003.tb02384.x.] 
TE Connectivity, 2017, KPSI 355: Hampton, Va., Measurement Specialties, Inc., accessed June 21, 2017, at http:// www.te.com/commerce/DocumentDelivery/DDEController ?Action $=$ srchrtrv\&DocNm=KPSI_355\&DocType $=$ Data + Sh eet\&DocLang=English \&DocFormat $=$ pdf $\&$ PartCntxt $=$ CATWLS0016.

Torgersen, C.E., Faux, R.N., McIntosh, B.A., Poage, N.J., and Norton, D.J., 2001, Airborne thermal remote sensing for water temperature assessment in rivers and streams: Remote Sensing of Environment, v. 76, no. 3, p. 386-398. [Also available at https://doi.org/10.1016/S0034-4257(01)001869.]

Torgersen, C.E., Price, D.M., Li, H.W., and McIntosh, B.A., 1999, Multiscale thermal refugia and stream habitat associations of chinook salmon in northeastern Oregon: Ecological Applications, v. 9, no. 1, p. 301-319. [Also available at https://doi.org/10.1890/1051-0761(1999)009[0301:MTRAS $\mathrm{H}] 2.0 . \mathrm{CO} ; 2$.

Trimble Navigation Limited, 2009, Trimble R8 GNSS Receiver user guide (revision a): Sunnyvale, Calif., Trimble Navigation Limited, 78 p., accessed June 19, 2017, at http:// trl.trimble.com/docushare/dsweb/Get/Document-666214/ R8-R6-R4-5800M3_v411A_UserGuide.pdf.

Turnipseed, D.P., and Sauer, V.B., 2010, Discharge measurements at gaging stations: U.S. Geological Survey Techniques and Methods, book 3, chap. A8, 87 p. [Also available at https://pubs.usgs.gov/tm/tm3-a8/.]

Upper Loup Natural Resources District, 2016, Upper Loup Natural Resources District Voluntary Integrated Management Plan: Olsson Project No. 015-2429, 33 p., accessed June 6, 2017, at https://dnr.nebraska.gov/sites/dnr.nebraska. gov/files/doc/water-planning/lower-platte/upper-loupNRD/2016UpperLoupDraftIMP.pdf.

U.S. Department of Agriculture, Farm Service Agency, 2017, NAIP Imagery: U.S. Department of Agriculture web page, accessed June 21, 2017, at https://www.fsa.usda.gov/programs-and-services/aerial-photography/imagery-programs/ naip-imagery/.

U.S. Geological Survey, 2004, Policy on the use of the FlowTracker for discharge measurements: U.S. Geological Survey Office of Surface Water Technical Memorandum 2004.04, accessed June 2, 2017, at https://hydroacoustics. usgs.gov/memos/OSW2004-04.pdf.

U.S. Geological Survey, 2017, National Water Information System - Web interface: accessed September 30, 2017, at https://doi.org/10.5066/F7P55KJN.
Vatland, S.J., Gresswell, R.E., and Poole, G.C., 2015, Quantifying stream thermal regimes at multiple scales - Combining thermal infrared imagery and stationary stream temperature data in a novel modeling framework: Water Resources Research, v. 51, no. 1, p. 31-46. [Also available at https:// doi.org/10.1002/2014WR015588.]

Wagner, R.J., Boulger, R.W., Jr., Oblinger, C.J., and Smith, B.A., 2006, Guidelines and standard procedures for continuous water-quality monitors - Station operation, record computation, and data reporting: U.S. Geological Survey Techniques and Methods, book 1, chap. D3, 51 p., 8 attachments. [Also available at https://pubs.water.usgs.gov/tm1d3.]

Winter, T.C., Harvey, J.W., Franke, O.L., and Alley, W.M., 1998, Ground water and surface water a single resource: U.S. Geological Survey Circular 1139, 79 p.

Winter, T.C., LaBaugh, J.W., and Rosenberry, D.O., 1988, The design and use of a hydraulic potentiomanometer for direct measurement of differences in hydraulic head between groundwater and surface water: Limnology and Oceanography, v. 33, no. 5, p. 1209-1214. [Also available at https:// doi.org/10.4319/10.1988.33.5.1209.]

For more information about this publication, contact

Director, USGS Nebraska Water Science Center

5231 South 19th Street

Lincoln, NE 68512

(402) 328-4100

For additional information visit https://www.usgs.gov/centers/ne-water

Publishing support provided by the

Rolla Publishing Service Center 



\section{$+x+2 x=$}

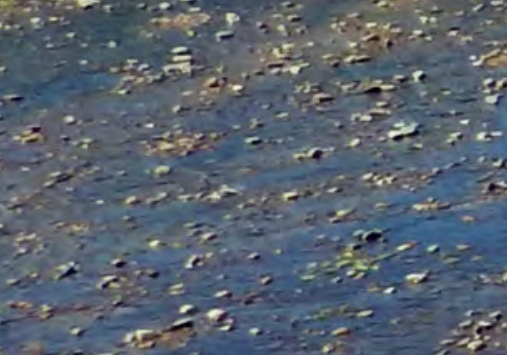

